

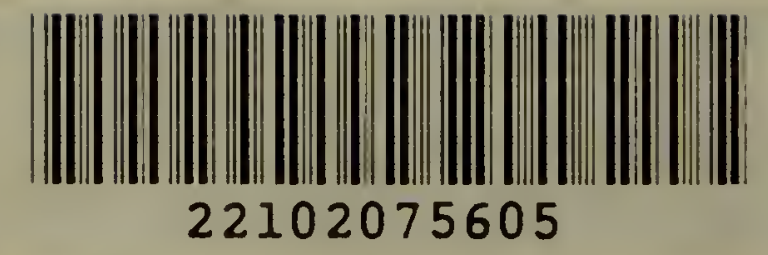




\section{Med K2701}





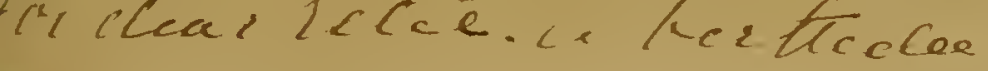

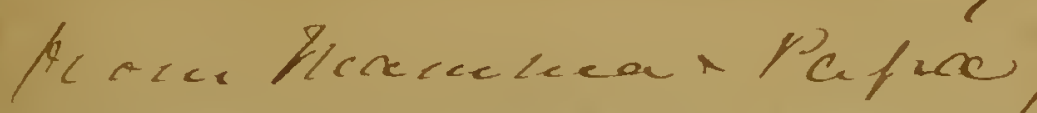

NATURAL HISTORY RAMBLES,

\title{
THE SEA-SHORE.
}

BY

\section{PROFESSOR P. MARTIN DUNCAN,}

\author{
M.B. (LOND.), F.R.S.
}

HONORARY FELLOW OF KING'S COLLEGE, LONDON.

PUBLISHED [*NDER THE DIRECTION OF THE COMMITTEE OF GENERAL LITERATURE AND EDUCATION APPOINTED BY THE SOCIETY FOR PROMOTING CHRISTIAN KNOWLEDGE.

SOCIETY FOR PROMOTING CHRISTIAN KNOWLEDGE :

LONDON: 77, GREAT QUEEN ST., LINCOLN'S-INN FIHLDS :

4, ROYAL EXCHANGE; 48, PICCADILLY;

AND BY ALL BOOKSELLERS.

NEW YORK: POTT, YOUNG, \& CO.

$$
1879 \text {. }
$$


LONDON :

WYMAN AND SONS, PRINTERS, GREAT QUEEN STRERT, LINCOLN'S-INN FIELDS, W.C.

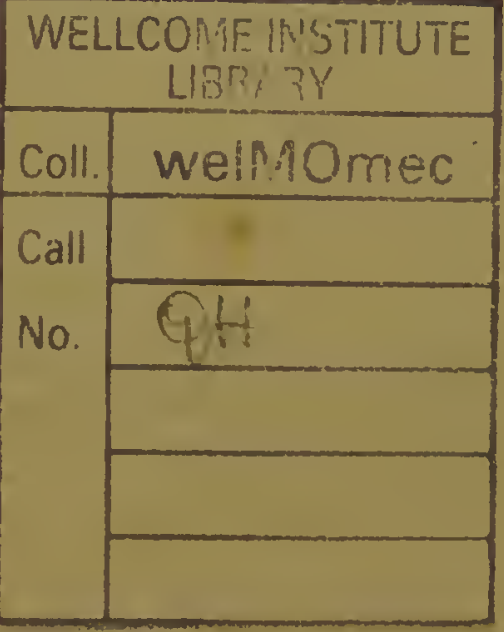




\section{INTRODUCTION,}

A LITTLE book on the Animals and Plants of A the Sea-shores of Great Britain and Ireland, if written in a popular manner, must, fortunately, be more or less of a compilation from the works of those great British naturalists who laid the foundation of our zoological knowledge; and from those of the observant naturalists who have already written on this subject. Fortunately the great works of such men as Montagu, Dalzell, Johnston, Forbes, Bell, Coldstream, Couch, Harvey, Hincks, and Gosse were written by enthusiastic describers of nature; and the charming volumes of such naturalists as my friend Rymer Jones are replete with interesting truths.

To those authors I am under great obligations, as well as to Mr. Bowdler Sharpe; and I have quoted them often very fully. Scientific terms and names have been omitted as much as is possible; and the contents of the book have been made to refer especially to the inhabitants of the Shore, or to that part of the sea-coast which is between and near, high and low tide-marks. 



\section{CONTENTS,}

CHAPTER I.

The Sea-shore, its nature and limits, beginning and ending, Breadths and Zones-How worn-Its Sand, Pebbles, Rocks, and Mud-The growth of the Shore, its former extension, the Wreck of the Land-Geological changesZones of Life and Depth limiting the Shore-The Natural History Provinces of the Shore . . . . . page

\section{CHAPTER II.}

The Plants near the Shore-The difference between Inland and Coast Vegetation-The Maritime kinds of the ordinary British Plants and their especial localities-Seaweeds of the Shore between high and low tide-markThe olive, green, and red kinds-Corallines and Nullipores .

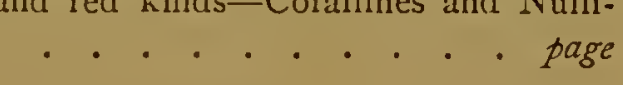

\section{CHAPTER III.}

The Microscopic Plants and Animals-Diatomacex-Animalcules and Spores-The Foraminifera-Sponges, and their Reproduction and Iabits - The Shell-boring Sponge... . . . . . . . . . . . page 


\section{CHAPTER IV.}

The Jelly-fish and other Hydrozoa-Planula and Hydra tuba-Sertularian or Garland Polypes-Plumularia-The Hydractinia-Budding Jelly-fish-The Sarsia-Campanularian Polypes-Lamp Hydrozoa or Lucernarians

\section{CHAPTER V.}

The Sea Anemones-The Strawberry Anemone, its Construction, Habits, and Physiology-The different kinds of Anemones-The Divisions of the Anemones-The Tuedia, Dianthus, Thick-tentacled, Daisy, Gem, and Troglodyte Anemones-The Parasitic kinds-The Muddwellers-Notes on some points of Microscopic Interest

page 102

\section{CHAPTER VI.}

The Stony Corals and their internal construction-Caryophyllia - Balanophyllia-Sphenotrochus; Alcyonarians and Tunicata of the shore . . . . . . . . page I29

\section{CHAPTER VII.}

The Sea Mats or Bryozoa-Flustra, Bowerbankias and other Moss Animals-The Sea-shore Worms and their Divisions: The Ribbon-worms, the Nemerteans, the Sea Mice, the Sigalion, the Sanguine Eunice, the Sao; their construction. . . . . . . . . . . pase I40 


\section{CHAPTER VIII.}

The Shore Worms continued-The Nereides, their Proboscis; the Laminated Nereis, and its breaking-up and reproduction-The Pearly Nereis, the Pelagic NereisThe White Rag-worm - The Lug-worm, its anatomy and physiology - The Spirorbis - The Serpula - The Sabellæ-The Cirratulus-The Chætopterus . . page I 58

\section{CHAPTER IX.}

The Star-fishes:-The Cross-fish-The Common Spiny Cross-fish-The Small Cross-fish-The Eyed CribellaThe Common Sun Star-The Brittle and Sand StarsThe Common Brittle Star-The Daisy Star-Points in anatomy-The Long-armed Brittle Star-The Sand Star - The Sea Urchins of the Shore . . . . . page

\section{CHAPTER X.}

The Common Shore Crab-The Great Edible CrabThe Velvet, Spider, Pea, Hermit, and Hairy Porcelain Crabs-The Spiny Galathen-The Spiny Lobster-The Gebia or Burrowers-Shrimps, Prawns-Case-making Crustacea-The Sandhoppers and Entomostraca-The Barnacles, and their transformations-The Insects of the Shore-Beetles and Wingless Insects . . . page 193 


\section{CHAPTER XI.}

The Shell-fish :-The Solen, Cockle, Pinna, Telline, and their peculiarities-The Limpet, Periwinkle, Purple, Whelk, Earshells, and Chitons-The shell-less kinds

\section{CHAPTER XII.}

The Shore Fish :-The Fifteen-spined Stickleback and its nests-The Viper-weaver-The Father-lasher or Lucky Proach-The Rock Goby or Miller's Thumb-The Twospotted Goby-The One-spotted Goby and other species -The Suckers :-The Cornish Sucker-Montagu's Suoker - The Connemara Sucker-The Shanny-The Halfbeaks-The Sea Adder or Pipe-fish-The Three-bearded Rockling-The Sand Eel or Lesser Launce . . page 240

\section{CHAPTER XIII.}

The Shore Birds:- The Ox-birds-The Ringed Plover - The Godwits-The Knots-The Golden Plover-The Grey Plover-The Waders-The Large Curlew-The Whimbrel-The Redshanks-The Greenshanks-The Sandpipers-The Cormorants-The Sea Swallows-The Turnstones and Stints-The Gulls . . . . . page 253 


\section{THE SEA-SHORE,}

ITS ANIMALS AND PLANTS,

CHAPTER I.

The Sea-shore, its nature and limits, beginning and ending, Breadths and Zones-How worn. Its Sand, Pebbles, Rocks, and Mud-The growth of the Shore, its former extension, the Wreck of the Land-Geological changes-Zones of Life and Depth limiting the Shore-The Natural-History Provinces of the Shore.

THE sea-shore is the debatable ground, where the sea is constantly striving to wear away the land. It is the present limit to the ocean and sea, and a little beyond, for it reaches inland further than the wildest waves and the highest tides can attain.

Where the sea-shore begins and ends, is a matter of opinion; but all of it is influenced in some way or other by the sea. In some places, high cliffs or rocks keep the sea from driving in upon the land; they are lofty, and may reach for miles along the coast. The high tide comes up their steep faces for many yards, and when it retires, a rocky strip is seen at their feet, and thence a breadth of rock, shingle, or sand, leads down with a greater or less slope to the water's edge. Here there can be no doubt how far the shore reaches 
inland, for the cliffs limit it. In other parts of our own and other maritime countries, there may be no high land on the coast; but marshes and low lands, with or without sand-hills, form barriers to the incursion of the sea. The highest tides have their limit in those places, but the wash of the sea and the spray, together with the drainage of the sea into the land, make the water saltish for some distance inland, and the earth close by is sodden with salt. Then, long stretches of mud or of sand form the slope, over which the sea rolls up to the land, and which is exposed and remains more or less wet at low tide.

In these low-lying parts of the coast the shore is not very distinctly separated from the land, and often miles of swamp, marsh, and sand-banks are invaded by the sea during storm and very high tides. The ditches near the sea contain salt or brackish water, and the whole of this kind of coast-line has a peculiar and desolate appearance. If these two kinds of coast are taken as the extremes, all the varieties of seashores will fit in between them; but still it will appear that whilst in some the limit between the land and the sea is very decided, in others it is not so.

Seawards, the shore is very variable in its extent. In some places it may barely exist, or may only be a ledge of rock, between the cliff, the high land, and the water ; and in others, miles of sand, shingle, and mud may be between the furthest reach of the waves and the limit of the low tide. The commonest examples of shores, are those which are between these extremes. Some sea-shores slope very gradually to the sea, and their extent is then usually great ; and others, 
which are limited in their breadth, are more precipitous. Perhaps it is best to say, that a sea-shore is the part of a coast which, at some time or other, is covered or uncovered by the sea; and that it has an extension inland, where the spray and wind are felt and act on the land, and also seawards, where some shore is only uncovered during excessively low tides. According to this view, it is possible to portion out a sea-shore, into a greater or less number of breadths, which may be placed, side by side, from the land to the sea. Firstly, a breadth will pass along the coast, and will contain the marshy, swampy land, or the hard rock down to the edge of the highest tide-mark. It may be miles across, or only a few feet in extent. Secondly, a breadth will be found between this last and the sea, where it is highest during common tides and storms. Thirdly, a breadth will exist four times in the twenty-four hours, as dry land, and for the rest of the time it will be beneath the waves, and this is situated between ordinary high and low-tide marks. Finally, a breadth will be between this last and the everlasting sea; it is narrow, and is only uncovered for a few hours, in the months of the year when there are what are called "low spring tides." These four breadths are termed Zones, or belts; and in common language the first is the beach and coast-line, the second is the shore, the third is the tide-shore, and the fourth is "low spring shore."

Differing in their extent, and in the nature of their surface, in every few miles of the coast of a maritime country like Great Britain, the zones have their peculiar animals and plants, and waifs and strays,- 
the wreckage of the sea, of its floor, and of the coastline. When the whole of the shore slopes very rapidly to the sea, the third and fourth zones are small in extent, but when the slope is gradual, they are large. And when the tide rises much and falls correspondingly, the third zone is usually uncovered but for a short time. The tide usually moves along the shore, and does not simply come in on to the land and recede; for one tide moves in one direction and the next in the opposite. Thus floating substances are carried along the coast for miles, by the rising tide, and come back again, more or less, with the falling tide.

Tide, wind, and wave, for ever act on the surface of the zones, but their action is the greatest on those which are landwards. There are other wreckers of the coast ; for the heat of the sun, the winter's frost, the rain, and the chemical action of the air, one and all crumble and break off pieces of rock or earth. These fall on to the tidal shore, and are rolled here and there, and up and down, to be turned into mud, sand, and pebbles. The cliffs and bold headlands are worn year by year, and during centuries they lose much, and retire landwards. Needles and "no. man's lands" stand out on the shore, or out at sea, testifying to the former extension of the land; and shore exists where there was once high solid rock. The shore consists of the worn surface of the old land, rock, or earth, and this is usually hidden by stone or stuff which has fallen from the cliffs, and by sand, or mud, or pebble and stone, which the tide has swept along. But often the jagged or rounded remains of the former rock project out of the sand, 
mud, and stone on the shore, and they may be bare, or covered with sea-weed. In other spots, the hard rock is hollowed out into places which let the water stand in them like so many puddles, pools, and ponds, when the tide has gone down. These are often crowded with marine plants and animals of the shore. The rolling stones, the wash of the tide, and the rush and drawback of the waves, are ever wearing off the surface of the shore and grooving it, or planing it flat, and in some places where the stones do not collect, this is very evident; but where they form great masses of pebbles or shingle, it cannot be readily seen.

'There are many shores around Great Britain, where the rock is hard, which are rarely covered with pebbles, boulders, and sand; and the sea-weed grows on them and protects them against the sea. But usually the rock is only exposed here and there, and the stones which collect and cover much of it, come from a distance, and are on the move at every tide. In some places, where the coast is composed of clay or soft sandstone, the shore is muddy, soft, and may be uncovered or covered by stones.

The wear of the sea is but little seen in such places as this, and still less so where the coast is low and flat, and the shore is very extensive and the water is shallow for a long distance. In fact, on many of these flat shores, instead of erosion taking place, the sea is adding to the land by depositing. This is particularly the case at the entrance of great, and of many small rivers. Their mud collects in the shallows at their mouths, and is added to by sand and shingle, so that 
land grows seawards, instead of the reverse. The sea-shore is then, usually, uninviting and often consists of large mud flats. Again, in some localities, where much sand collects on the surface of the rock forming the sea-shore, it may be "quick" in many places. The rising tide gets under the sand, which suddenly becomes like so much sand and water, and the falling tide leaves it hard for a while. The ordinary condition of a sandy shore is either that of a number of very slightly rounded stretches of sand, with drainagestreams between them, or it is pretty hard, readily dug into, and marked on the surface by ripples. The ripple-mark on sand always strikes the observer; it represents little ripple-like waves, wonderfully regular, and each has a ridge and a valley. They are very lasting, but disappear on the slightest movement of the wet sand, as the tide comes in. These little ridges and valleys are not found when the water covers the sand at a considerable depth, but they are especially seen between high and low spring-tide limit. Such marks can be made, artificially, with sand, for instance on the bottom of a large basin. If some sand is placed on the bottom, and water be poured in, and the edge of the basin be pushed, a toand-fro movement of the water will occur, and it will be continued down to the sand. As the motion ceases, the sand will be seen to collect in ridges, side by side, and they will be perfect when the motion stops. Motion of the sea-water in one direction over soft sand will not produce ripple-mark well, but a slight toand-fro movement will do it to perfection. Infinitely more wonderful than these ripples, are the pebble 
beaches, for they often extend for many miles, and have a very considerable thickness. Worn in the first instance, from distant rocks, born of huge boulders, which the mighty waves laden with rolling stones have broken down, the pebble is formed by rolling against others, and the result of its wear and tear is carried off in the form of sand. They travel miles and miles along the coast with the tide, and therefore it is very common to find one kind of rock forming the coast-line, and the shore close by having pebbles made up of stone which is not known to be near at hand. Thus, on the coast of South Devon, the red rocks form the coast-line; they are sandy, and are covered in some places by a beautiful green vegetation. The sea is often of the brightest blue, or grey, when the sky is not much tinted with colour. But the sea covering the shore at high tide looks whitish, and this is produced by the white and light slate-coloured pebbles which reach up close to the red rocks. They are not made up of red sand; on the contrary, they are of gray and bluish limestone, and come from rocks which are situated miles to the west. Further east, the Chesil Bank is seen, and it is an enormous shore of pebbles, which have been carried along the coast and have found an uncertain resting-place there. Every tide makes more sand out of the hardest pebbles, as they knock one against the other and wear away, and the sand already made, scrubs them as it is hurried hither and thither, by the waves. In some places where the sea is giving up rather than taking off land, the sand which is cast up, may be the result of the wear of distant pebble-making, or it 
may be composed of myriads of broken tiny shells which once lived in shallow water.

It has been already stated, that the sea is encroaching on the land in some parts of England, and that it does not do so in others, whilst it appears to be giving place to land elsewhere. In the first instance the sea-shore must grow as it were, must increase landwards, and it really does so at different rates, in different parts of the country. In some parts of the coast a yard is lost every year and the sea comes in on the land so much the more. Cliffs wear away and fall; fields, houses, and even towns have tunbled on to the shore in times gone by, and the sea-shore is on their site but lower down. But all the space once occupied by cliff and rock is soon worn by the sea and is covered gradually by the tide, and after years have elapsed this fore-shore is deepened seawards by the rolling stone and rushing waves, so that the visible beach or shore diminishes in size, unless a corresponding landward extension takes place. Although the cliffs and rocks fall, and their remains are swept away from the level of the shore, by currents, tides, and waves, yet, as has already been noticed, much of the ruined surface, levelled down as it has been, is covered up by relics of their wear and tear or by stone brought from a distance. It is only after some severe gale of wind, accompanied by a very high tide, that these stones and covering-up relics are swept away and the old rock-surface comes in view. All these matters are of importance, for the living creatures of the sea-shore depend upon the state of things, in each of the zones, for their ability to exist and flourish. 
Where the coast has been low and the sea has gradually encroached, the remains of stumps of trees are often exposed after a gale. Then, what is called part of a submarine forest isopened to thesight. There are many of them around England and especially on the coast of Norfolk and Essex, on the east; in many places on the south coast as far as Torbay; and on the west they are found in the Bristol Channel, and about Holyhead and the river Mersey. Sometimes it appears that the sunken forest has not been altogether produced by the encroachment of the sea on the land, and that sinking of the coast, or slipping of part of it, has caused the event. When the sea comes in on the land, it wears everything before it, and any forest land would in most instances be completely wrecked and the roots of the great trees would be worn and torn out of the soft earth and carried off to sea, by the waves, tides, and currents. On looking at some smaller forests which are laid bare at very low tides, it is found that they consist of stumps of trees of great size, whose roots are still in the clay in which they grew, and a quantity of mud and sand is between the stumps and protects them from the usual action of water on submerged land. It appears that some movement of the earth's crust had caused the coast to sink down, and then the sea invaded, without wearing off the land. The trees were ruined by the sea-water, and broken off, and the mud, sand, and stone collected around the stumps.

It is not uncommon to see collections of stone and shells high up on the face of a rock or cliff, and when they are carefully examined, they are 
found to resemble a bit of a shore or a piece of the beach, hoisted up many feet above the present line of the waves and tides.

They are called raised beaches, and they were formed by an upheaval of part of the coast with its shore during movements in the crust of the globe. There was a shore and a cliff, as there may be now, and the whole was pushed up some twenty, thirty, or more than a hundred feet beyond the reach of the highest tides and waves. In years past the waves broke upon the cliff beneath the upraised portion, and wore it away bit by bit; and then the air and sun acted with the rain in wearing it, and now only a portion remains.

Every coast-line is subject to these sinkings-down and upheavals, and of course a sea-shore is produced rapidly, and is made broad and shallow during the first kind of occurrence, and is stopped and has to be formed afresh during the last. As these remarkable movements of the outside of the globe are not universal, and affect some parts of a coast more than others, they will tend to give great variety to the sea-shores of a country. Together with the varying action of the tides, waves, and currents upon cliffs and rocks of different stones and earths, and of many hardnesses, these movements have made the shores of this country very curiously varied in their size and character.

It must be remembered that as new shores are formed, or old ones are extended, the zones are kept within their bounds, and that as one zone creeps in on the land, those to the seawards move up also; 
so that where there was once a between-tide zone there may now be deep water. This change in the position of zones is very important; for certain animals and plants of the shore only live in certain zones, and their increase or decrease in numbers depends upon the corresponding state of their special locality.

If a zone were suddenly cut off at the sides, by the action of the sea on cliffs, in making long inroads right into the land, the animals and plants would be separated from their neighbours by these cuttings. If a shore is made where there was none before, the animals and plants will migrate on to it from the zones on either side. In some parts of the sea-coast of England, there are zones where there are animals and plants almost unknown elsewhere, and it is because those parts have been separated from others for ages. On the other hand, many of the kinds of animals and plants of the sea-shores of France, Belgium, and Holland are found living in corresponding zones on the English and Irish coasts, and this tends to prove, that once on a time, these countries were all continuous on a coast-line, and that the separation has become perfect during ages, by causes even now in operation.

From the days when the waters were separated from the land, shores have been, and the sea has worn the land, and the land has been upheaved out of the sea. So varied is the history of the coasts and shores of our country, so changed has been the surrounding sea-floor and land over and over again, that their animals and plants represent offshoots of 
niany shores; and thus some kinds of creatures which now enliven the rock-pools and sands are found also in the Mediterranean Sea and on the distant coasts of Iceland, Greenland, and North America. Even British seaweeds have got to Australia. Living things, which can only live on the shores, and which cannot traverse the abyss of the ocean, are thus transported from land to land by emigration, along altering, forming, rising, and sinking shores.

The seaward limit of the shore is strictly that line which marks the greatest going out of the tide. Beyond this the water increases in depth, more or less suddenly, and the floor of the sea there is constantly submerged, it being very rarely exposed to the air during some low spring tides. Different animals and seaweeds live in this part of the sea, and they, as a whole, cannot struggle against the repeated changes of depth and the successive exposures to air which appear to invigorate the true animals and plants of the shore. Nevertheless, some of the shore creatures live in the depths beyond, and some of the dwellers in the sea beyond the shore, often come upon it. Moreover, some animals which are never seen alive on the shore when mature, but which swim freely in the ocean, commence their life on the shore under very different shapes. Many birds frequent the shore occasionally, and gulls and cormorants are there constantly on the look-out for food and prey, having come from their distant homes and from the open sea, their usual hunting-ground. Fish swim over the shore at high tides, and stragglers are often left behind; but they are not mecessarily of the same kind as 
those which always live on and about the shore. It may be readily conceived from these remarks, that there is a special assemblage of plants and animals which belong to the shore, and that the others are wanderers and occasional visitors only. This is quite in keeping with the knowledge of naturalists, and indeed they divide the coast-line into zones of life, which must, however, not be mistaken for the shore zones already noticed.

The zones of life are (I) the littoral zone, or tract between tide-narks; (2) the laminarian zone, from low water to fifteen fathoms; (3) the coralline zone, from fifteen to fifty fathoms. Then come other zones leading to the great depths. The animals and plants to be considered in this book, are restricted to the littoral zone; but it is not possible to draw a very hard-and-fast line between some of its dwellers and those of other and deeper parts; for some of them do wander into the shallows, whilst there are kinds which go from the shore down into the depths, without inconvenience.

The broad-leaved Tangles live in the laminarian zone, and it is called so from their Latin name, and therefore they limit the plants and animals of the shore, seawards.

It has been noticed that the animals and plants of the shores of our coasts are not the same everywhere, and that in certain parts some peculiar kinds are to be found. This is produced by climate, the nature of the sediment on the shore, the geological nature of the coast-line and inland parts, and the mineralogy of the district. And with regard to this last, it may 
be noticed, that where the rocks contain lime, or limestone and chalk, there certain shell-fish and corallines abound; but where this mineral does not exist, there they are comparatively or entirely absent. The British Islands extending to the north and south, and being washed by the North Sea, the Atlantic, the German Ocean, and the Channel seas, come within the limits of certain great natural history provinces. One is called the Boreal, and it extends across the Atlantic from Nova Scotia and Massachusetts to Ireland, the Faroe Islands, and Shetland Islands, and along the coast of Norway. That is to say, there are marine animals and plants which are found on the American, Irish, Scottish, and Norwegian shores, and which are either of the same kind or species, or of the same genus or group.

The next province is the Celtic, and it includes the coasts of England, Scotland, Denmark, Southern Sweden, and the Baltic, and all these places have animals of the shore and other zones in common. The Channel Islands and parts of our south coasts come within range of another province, called the Lusitanian, which is that of the west coasts of France, Spain, and of the islands off the coast of Africa. The Celtic province, however, is that to which most of our coasts belong; and it is a subject of great interest to know that many of the kinds of shelly mollusca, which are now living, lived in the last geological ages, and their remains are found fossil ; so that the condition of the coast-lines and shores and a part of the assemblage of animals and plants now living on them, have a remote ancestry. 
CHAPTER II.

The Plants near the Shore-The difference between Inland and Coast Vegetation-The maritime kinds of the ordinary British Plants and their especial localities-Sea-weeds of the Shore between high and low tide-mark-The olive, green, and red kinds-Corallines and Nullipores.

IT has been noticed that it is by no means easy to say where the sea-shore begins landwards. It may be limited by cliffs and mountain-ground, so that there is but little shore, and the tide-water then comes up the sides of the cliff; and it may reach for miles inland, amongst salt marshes, the ditches of which have salt water and marine animals and plants in them. Again, even when the shore is perfectly limited inland, there are proofs that the sea is near, long before it is reached. Trees usually get scarce, and often those which are seen, are much gnarled and bent, and covered with lichens. A new set of flowering plants is noticed, and the old favourites of the meadow and wood are absent ; and grasses, reeds, rusines, and many singular plants straggle on the sand and pebbles, out of the range of the tide, but within that of the spray sent in by a high wind. Common observation has enabled, even the most unscientific collectors of plants, to recognise what may be called a maritime, coast, or shore flora, 
just as they can distinguish a marsh, mountain, or wood flora beyond the range of the sea. A flora is the name for all the plants of a district, and it has been found that the sea-side and sea-shore floras of these islands are very rich in kinds. Indeed, there are many little local floras included in the great sea-

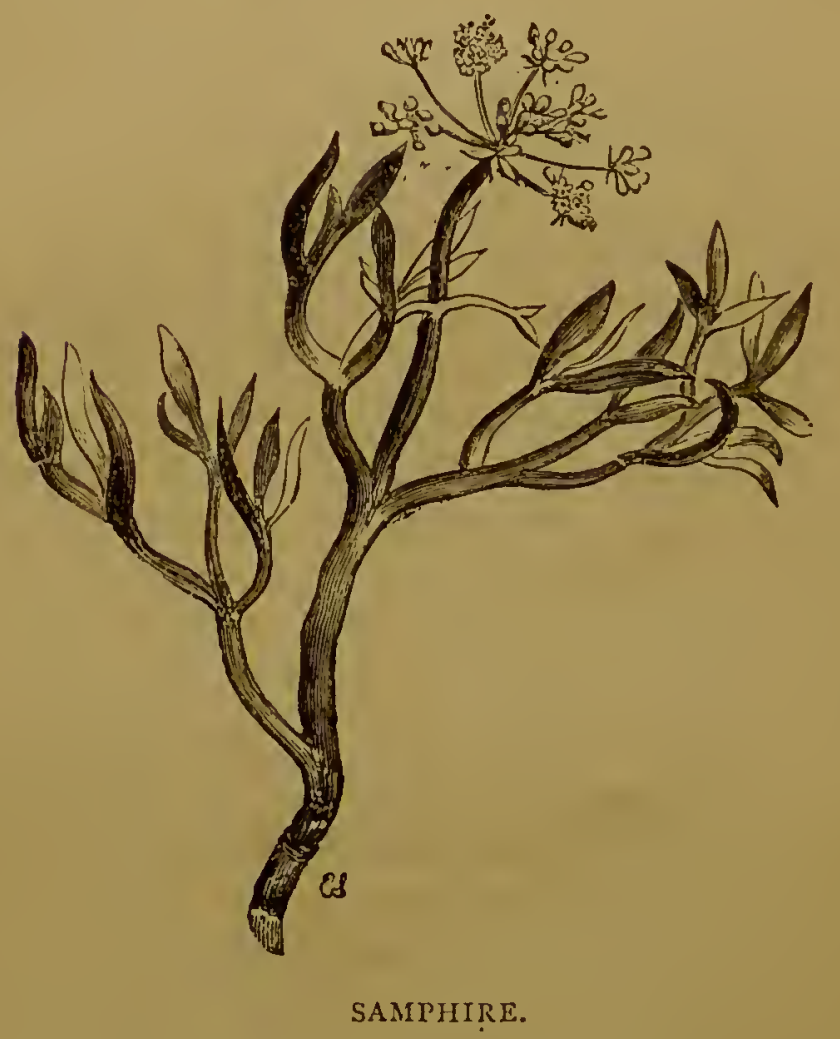

side one, for, as may have been gleaned from the previous chapter, the landscape, the nature of the rocks, and the vegetation of the shore, differ greatly in different parts. Each particular landscape by the sea, and every kind of soil there, has its little set of 
peculiar plants, some liking limestone, others clay, many rejoicing in sand, and some even finding nourishment amongst the highest pebbles.

Hence, on walking round our coasts, the plants, as a whole, will differ from those found inland, and at

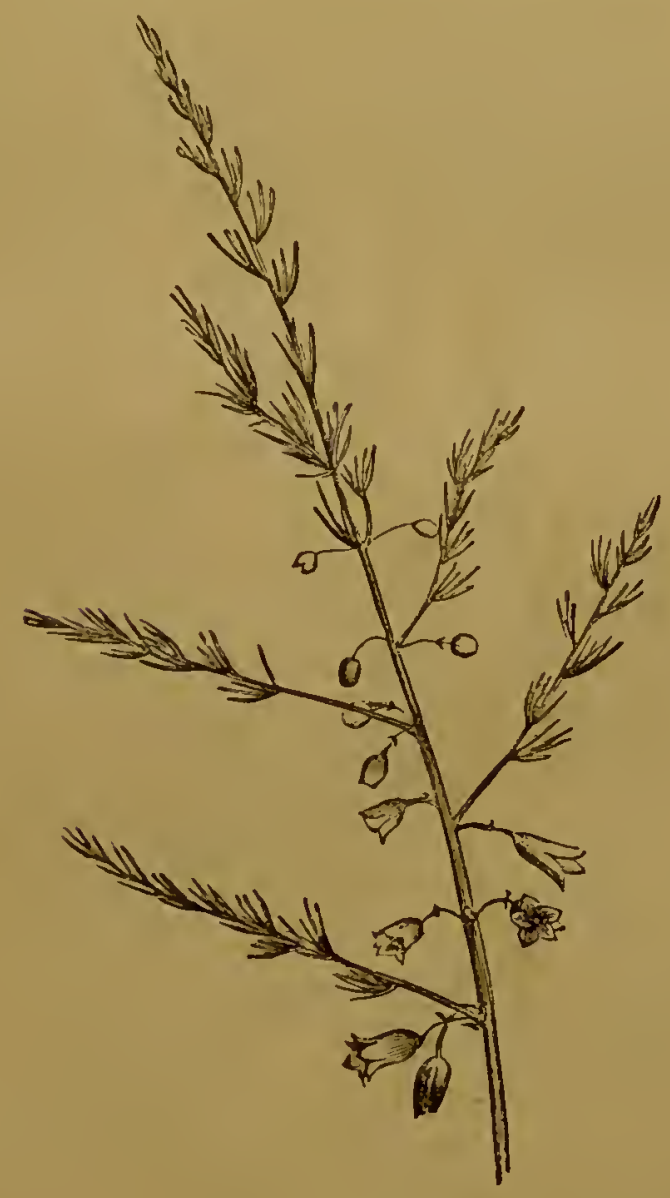

COMMON ASPARAGUS.

every turn or change of rock and scenery, new kinds appear. But many of the inland plants do go down far to the sea-side, and the art of gardening and all 
sorts of accidents have dispersed many plants, which originally were not dwellers near the sea; and, on the contrary, they have also removed sea-side plants, like Sea-Kale and Asparagus, inland and into our gardens. In many places, however, and where the sea comes up very close, the inland plants are not found. There is a very remarkable thing about this sea-shore and sea-side flora, and it is this, that nearly all the important groups, families, or genera of inland plants have a kind or two in it, and that there are few extraordinary novelties which would enable us to say that such a set of plants was destined for the sea-side. Thus the Pod-bearing order, which contains the pea, bean, clover, and such plants, has many species which are only found near the sea. The Toothed Medick (Medicago denticulatus), and the common Melilot, love sand and gravel near the sea; the Star Clover lives on a shingly beach near Shoreham; whilst two kinds of the genus Lotus live on dry places, two being found near the sea in Devon and Cormwall. There is a vetch, with a pale purple flower, on the pebbly beach of Weymouth, and another of a sulphur-colour likes such situations. Even the Poppy order has a kind with large golden-yellow flowers, with seedcases from 6 to I 2 inches long, living on sandy seashores; and this "Horned Poppy" has a very interesting companion, for a poppy with a bluish-white flower with a violet spot, lives in the fens and on sandy ground near the sea, and it is the kind which yields opium. ${ }^{1}$ The Cruciferous plants, of which the Wall-

'Sec Babington's 'Manual of British Botany,' 
flower, the Rocket, Cabbage, Mustard, \&c., are examples, are well and interestingly represented at the sea. There is a Sea-Stock living on the sandy sea-coasts of

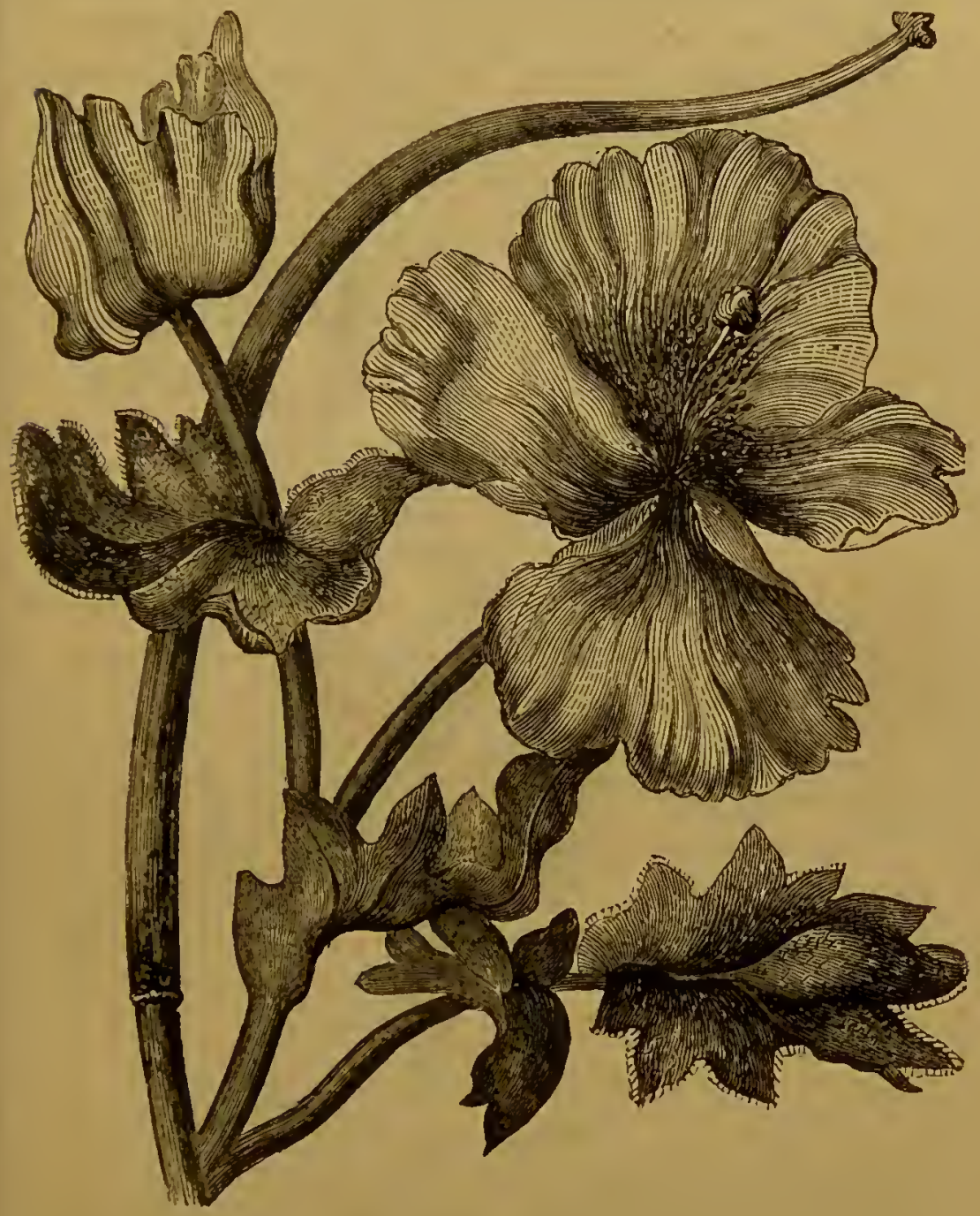

YELLOW HORNED POPIY.

Wales, Cornwall, and Jersey. The Wild Cabbage, the parent of all domestic cabbages, lives on cliffs by the C 2 
sea ; a Wild Mustard is at St. Aubin's Bay, Jersey ; a white Draba, not very unlike the common whitlow grass, is on sandhills by the sea in Islay. The Scurvy Grasses are all found on sea-shores, and constitute a shore group. Finally, there are the Purple SeaRocket and Sea-Kale, loving sandy shores, and there is

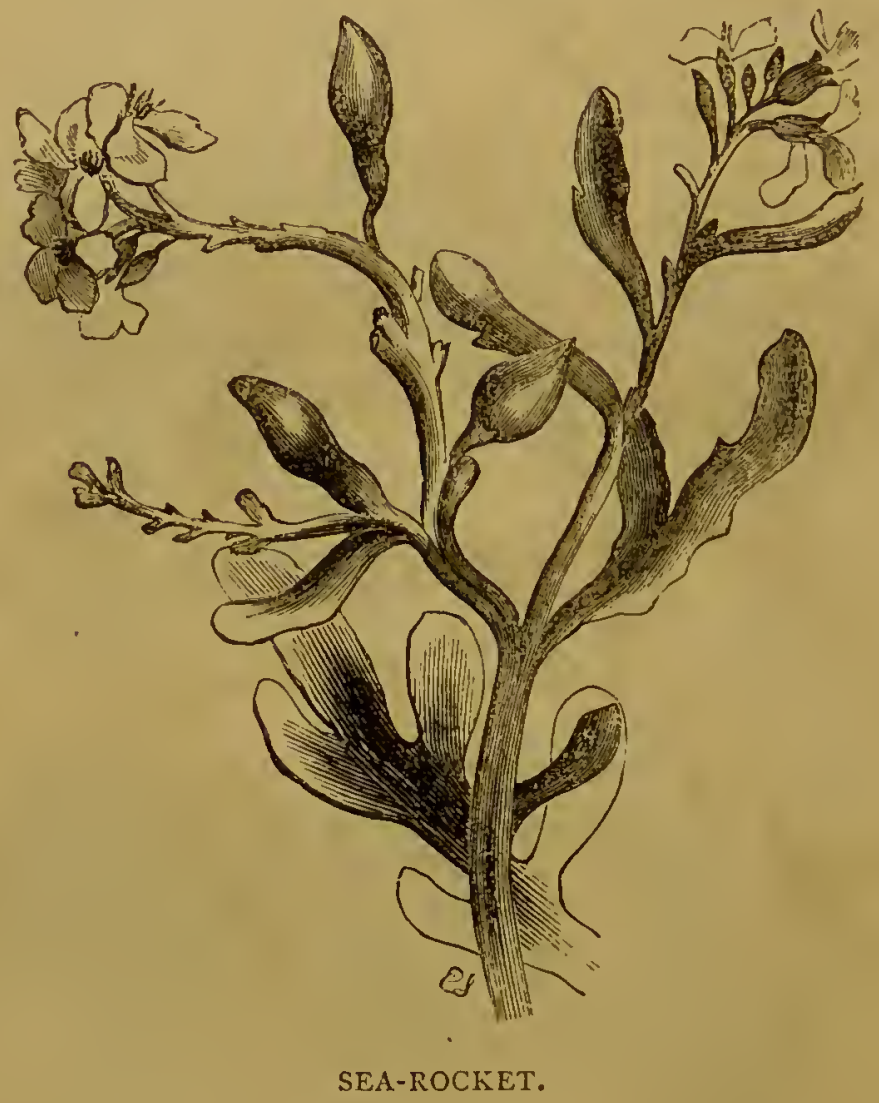

a rare wild Sea-Radish. Amongst other well-known inland orders of plants, such as the Violets, there is a rare one with its flowers wholly yellow, or yellow with the upper part purple, living on sands by the sea. 


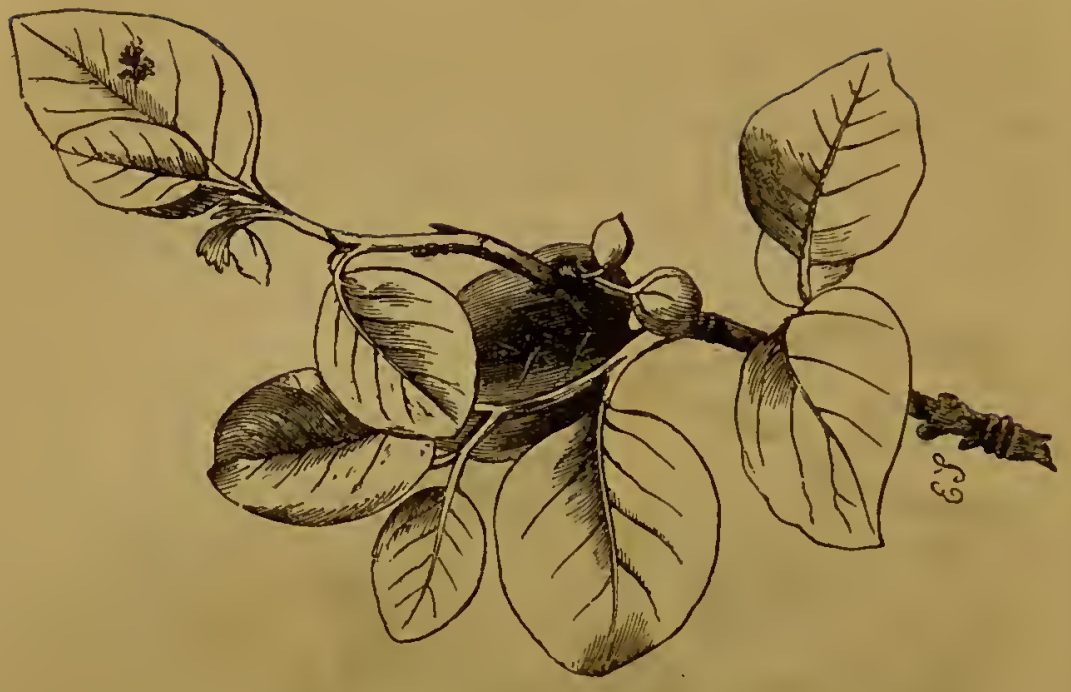

COTONEASTER VULGARIS.

littoralis of the south-west of England has whitestalked flowers. The Sea-Holly, with its blue flowers

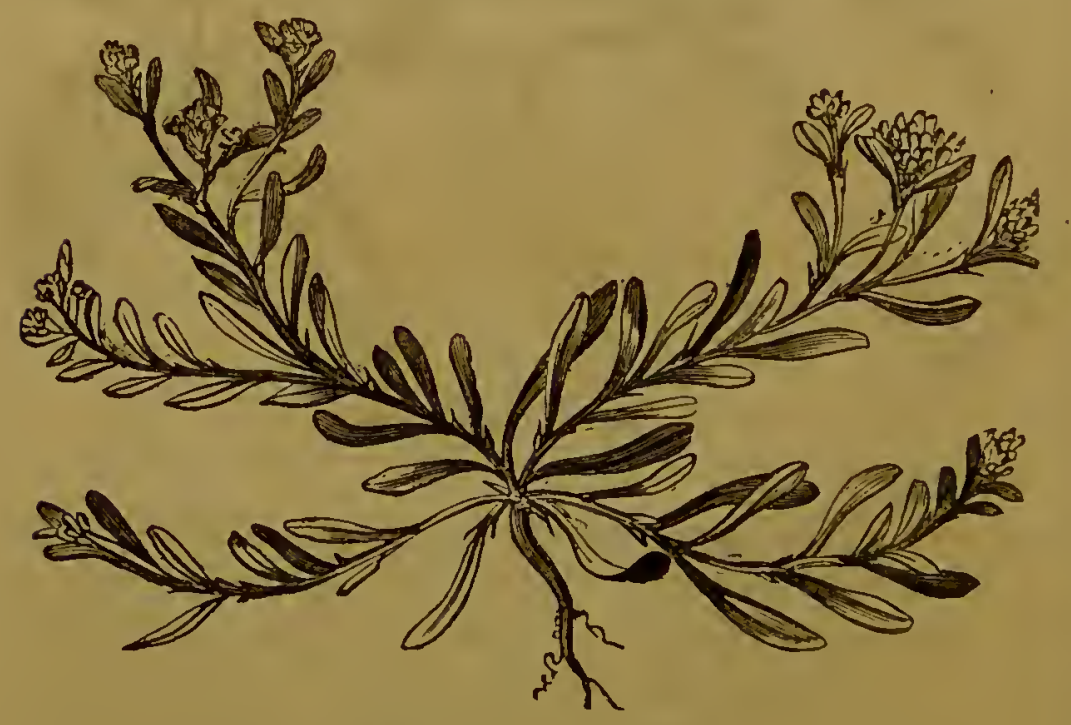

CORRIGIOLA LITTORALIS. 
in a head or umbel, lives on sandy sea-shores; the Wild Fennel, the Scottish Lovage, and the fleshy-leaved, whitish-flowered Samphire love rocks by the sea. The Sea-Carrot lives on the south-western coasts.

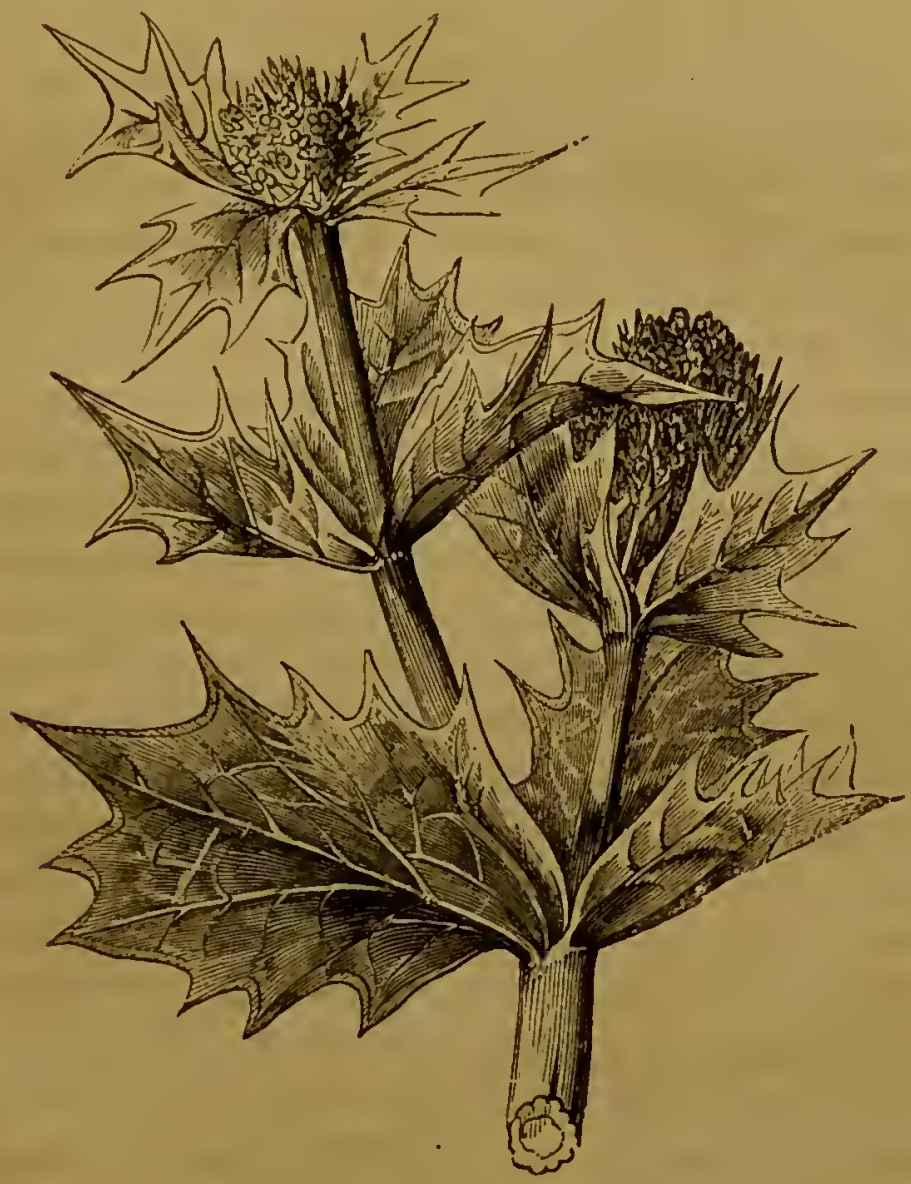

SEA-HOLLY (Eryngium maritimum).

'The Red Valerian is found on chalk cliffs ; but no other of its tribe, or of the Teazels or Scabious set, is 
found particularly as a sea-shore plant. Both the composite orders, of which the Daisy and the Asters are examples, and which form so large a part of the inland flora, have many sea-shore species. Thus, there is the Golden Samphire, allied to the Elecampane plant, the Sea-Diotis, the Sea-Feverfew, and the SeaWormwood. There is, or was, a wild Cineraria on the rocks of Holyhead, and there is a Thistle with pink flowers which loves sandy places by the sea. The Least Lettuce likes chalky places. One of the Centaury kinds lives on sandy sea-shores, and there is a sea-side Bindweed with very handsome pink flowers with yellow bands. One of the Bugloss tribe lives on northern sea-shores, and there is a curious Great Snapdragon which is to be found about cliffs overhanging the sea. The Primroses and Pimpernels are not inhabitants of the sea-shore, but two sets of plants, called Glaux and Samolus, belonging to their order, frequent the shore and salt marshes. Then there is the Sea-Lavender tribe with four kinds, all living in England, or Ireland, on rocky shores and salt marshes ; and the Thrift plant likes the shore as well as the mountain top, a distribution which is noticed also in the Sea-Plantain. Many of the Spinach tribe, such as the Glass Worts, the Sea-Beet, the Salsolas, and the Sea-Purslane, inhabit the shores, and some of them were formerly used in the preparation of barilla. Such a common thing as the Dock could hardly be found away from the sea, and there is really a Sea-Dock found on the marsh land; and the Channel Islands have a SeaSnake-weed. A thorny shrub with lancet-shaped silvery leaves, and attaining the length of from 4 to 
ITS ANIMALS AND PLANTS.

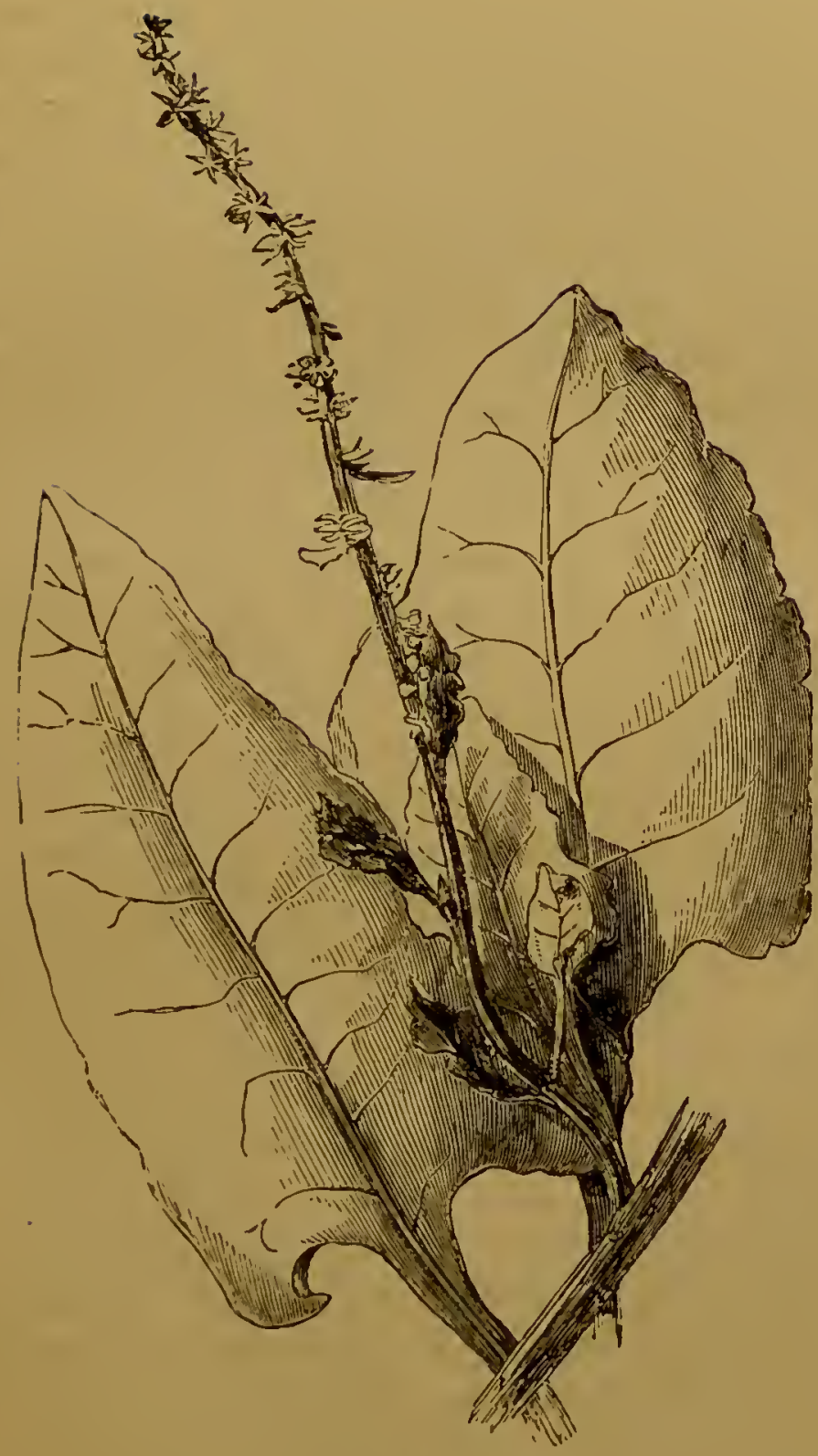

SEA-BEET. 
6 feet, frequents sandy spots and cliffs, on the southeast and east coasts, and is called the Sea-Buckthorn. There is also a Sea-Spurge. The Wild Asparagus, with a stem not one-third of the height of the cultivated kind, but the true parent of all asparagus, is a rare plant, but it has been found at Kynance Cove, Cornwall, Callar Point, Pembroke, and at Gosford Links in Scotland. Another important plant, the Onion, has its representatives on the rocks of Guernsey, and another called Chives is a Cornish cliff sea-side dweller. The Rushes have several kinds on salt marshes and shores, and there is a plant called the Zostera, with long leaves, which flourishes under water on many parts of the eastern coast. Belonging to the same botanical order is the Ruppia maritima, found at Newhaven and Guernsey.

The Sea-Sedges, a Cat's-tail Grass, a Fox-tail Grass, an Agrostis, a sea Reed, and a common Poa grass, with a root-like bulb, are familiar objects on swampy sea-shores ; and a whole group of grass plants belonging to a tribe called Sclerochloa, inhabit sandy seasides. The Couch-Grass, dwells there also; and the list may be closed by noticing the Sea-Barley, a tiny plant, but loving sandy pastures near the sea. And amongst the ferns a Spleenwort lives on rocks over the sea.

These are all plants of a complicated structure, and produce seed. But those about to be noticed, are the true sea-weeds, which have a simple construction and belong to the cellular plants.

Where the land plant ends, the Sea-weed begins, and as some flowering plants or grasses come close to 
the edge of the high spring tide, so some sea-weeds choose that position, and appear to like a dry time for awhile, and a refreshing return of the salt water at distant intervals.

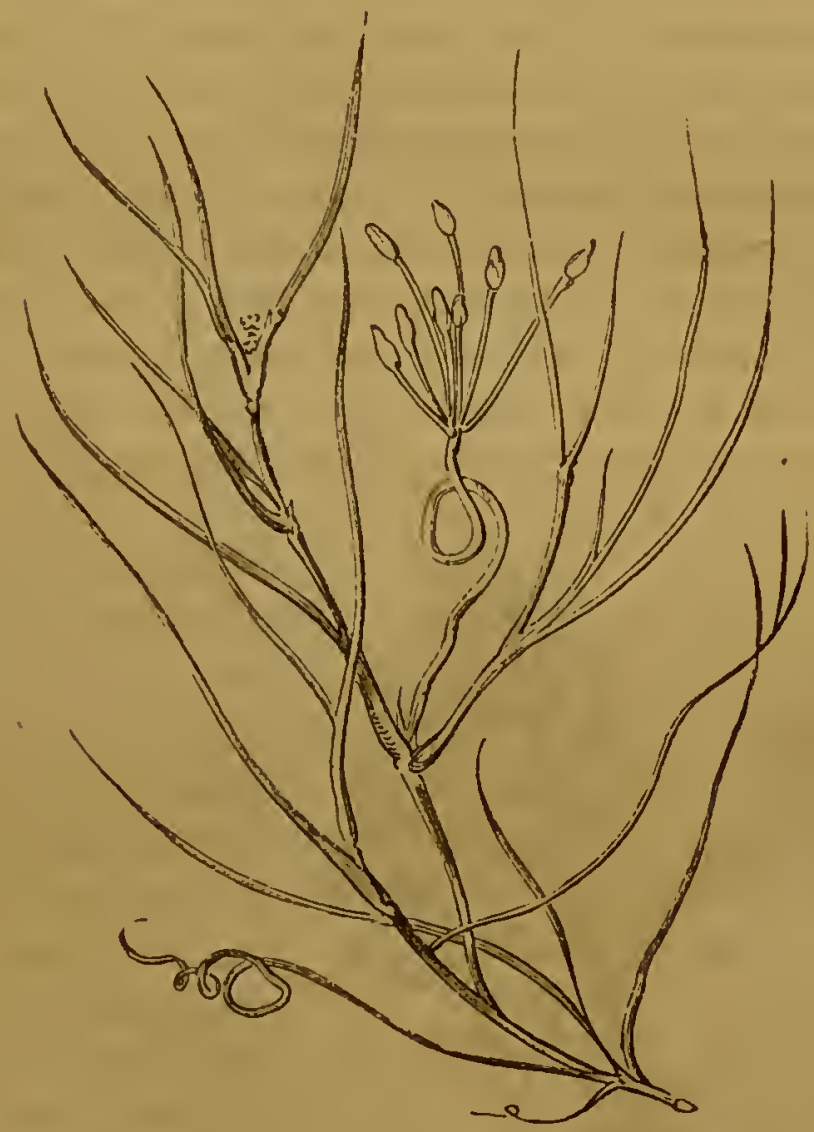

RUPPIA MARITIMA.

One of these sea-weeds abounds on muddy seashores, at the entrance of rivers and marshes, and positively adheres to the roots of flowering plants. North Wales, Shoreham, the Essex coast, and the 
Shannon, are places where it is found in abundance. Moreover, like most of the sea-weeds, it has a wide distribution, for it is found on the Atlantic shores of Europe as far south as Spain. The plant is from 2 to 4 inches high, and consists of stems about as thick as stout bristles. They branch and give off side-twigs, like the veins of leaves in shape, and each ends in a curious curl. The whole plant is limp, and easily squeezed flat. It is of a dull purple colour, and from its curl endings has received a Greek name, "bostrukos," a ringlet. Old authors called it "Amphibia," from its locality, which has just been noticed; and it is remarkable, because most of the other red or reddish sea-weeds of its group live in deep water.

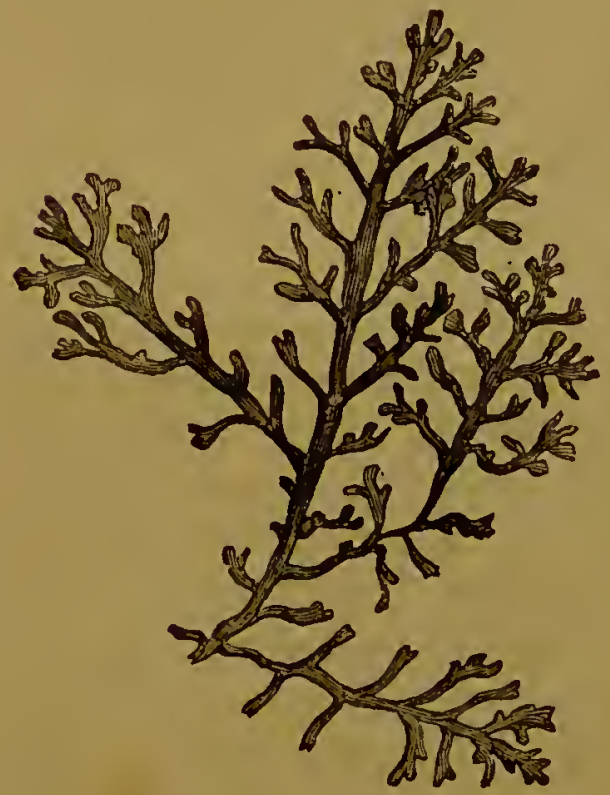

PINNATIFID LAURENCIA.

Another sea-weed which lives at the very top of highwater mark, but which is also found on the shores down to low-water mark, and still lower, is a fine plant often growing a foot in height. Its stem is roundand solid, and branched in what is called a pinnate manner, like a Mimosa leaf. It is yellow or livid green in colour, and is very sniall and starved at high- 
water mark; but it grows larger and larger until well under the sea. One of the kind is found on loose stones, where a rill of pure fresh water runs into the sea. In Scotland it was formerly eaten under the name of Pepper Dulse; but better things are now to be had. It is named Laurencia after a French botanist.

A membrane-like sea-weed, which grows upwards with swellings like a Cactus and which give it the appearance of a chain, is called the Little Chain Sea Opuntia (Catenella Opuntia). It is also a diveller on rocks, close up to high-tide mark, on our shores as far as the Orkneys.

Often at high-water mark, and on wood and stones down to half-tide level, there is a quantity of dark olive-green sea-weed, in small tufts, getting larger nearer the sea, which often looks dried up, shrivelled, and crisp. It grows in tufts when the water goes off rapidly, and it evidently requires exposure to the air for several hours in the day. Nearer the ever-rolling sea, the plant grows larger. It is called the Channelled Fucus, and has an expanded part or root, and a stem which branches in twos, and ends in two long cones of softish stuff which contain the reproductive organs or spores, called receptacles. It belongs to the same group of sea-weeds as the commonest of all, or that which has air-bladders on it and which crackle and burst under the feet. A differently-coloured high-water-mark weed is found at Yarmouth, Bantry Bay, Torquay, and Sunderland on sand-covered rocks. It lies prostrate and is of a pale green colour, forming masses or layers of excessively minute threads of vegetable tissue. It belongs to the genus Codium. 
The sea-iveeds called Wracks or Fucus are amongst the most common of the dark greenish-olive kinds, and one of them lives in a curious place on the shore. The stem or frond is from I to 2 feet

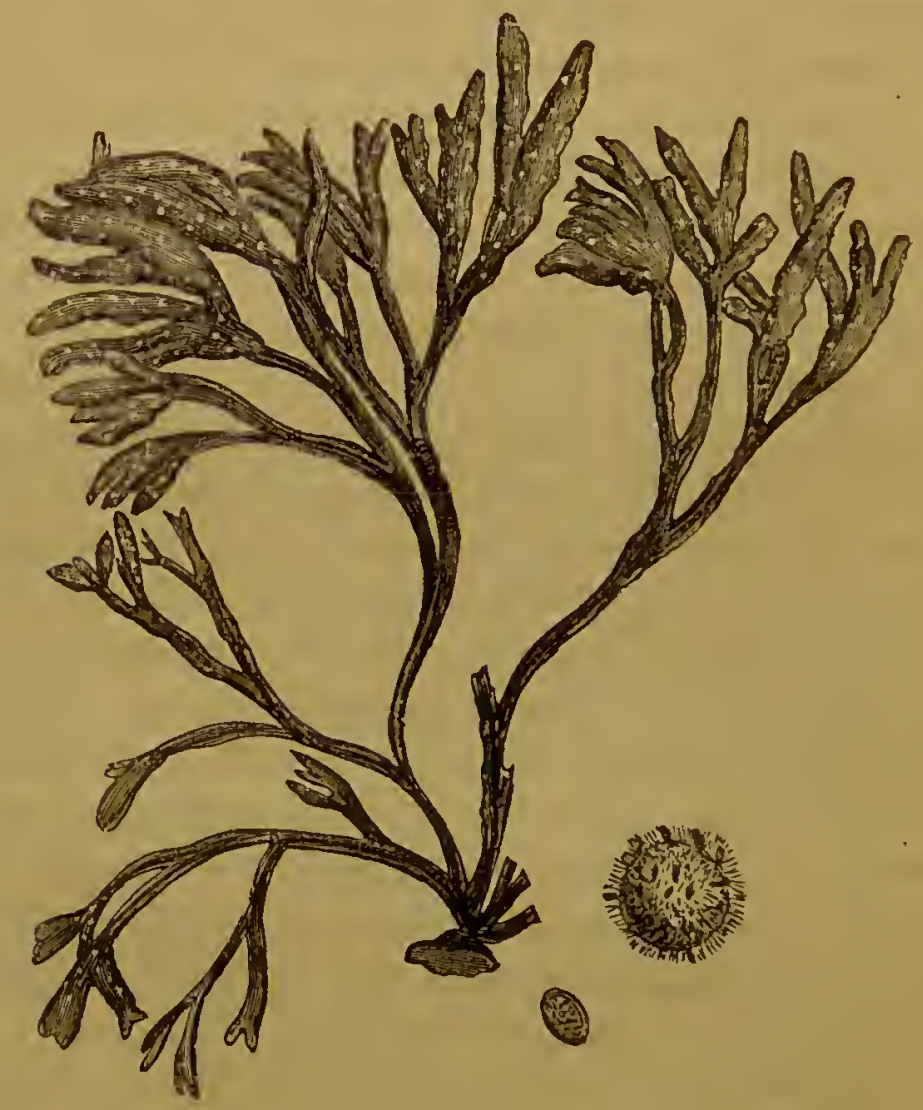

THE CHANNELLEN FUCUS.

long, and there is a kind of midrib to it, besides the cones or receptacles, at the tip of each branch. It is common from Orkney to Cornwall in many places, and is found where a good deal of fresh water mixes with the sea, but it is not restricted to such peculiar 
positions, for some of the most vigorous plants live in salt water, and some very transparent and weak ones in brackish water. The common Bladder Fucus is found everywhere on rocks and stones and wood left exposed at low water, and on artificial quays in estuaries extending up rivers as far as the water is decidedly brackish. Even in salt water it is noticed to flourish. The plant or frond is in long, flat, thin branches with a midrib, on either side of which are the bladders, which contain air. The branches end in thick gummy-feeling masses, which are turgid, rather pointed, and contain the spores. The colour is olive and it is lighter in the younger parts. It is found along the shores of the Northern Atlantic, extending even to the Tropics. It is used as manure, and also in forming kelp for the purposes of the manufacture of iodine. Cattle eat it in the winter, and of late it has been used in baths. A larger kind of Fucus grows from high-tide mark to mid-tide level, and it has large swellings on its stem, and the branches, which come off in whorls, are distended, as it were. It is used in the kelp manufacture and for covering up oysters. The Scotch shore-men call it the Sea-Whistle, for boys make whistles out of the larger air-vessels. (Harvey.)

The serrate Fucus, so called from its saw-like edges, has no bladders, it clothes the rocks at halftide level, is very common, and is found on the western shores.

On the rocky bottoms of submarine tide-pools, near low-water mark, all round the coasts of Scotland and England, is a weed with narrow fronds and pinnate ones of a lance-head shape, with spiny teeth on their 
edges. It is a clear olive-brown plant, and gets a verdigris tint when it is exposed. It is called the ligulate Desmarestia.

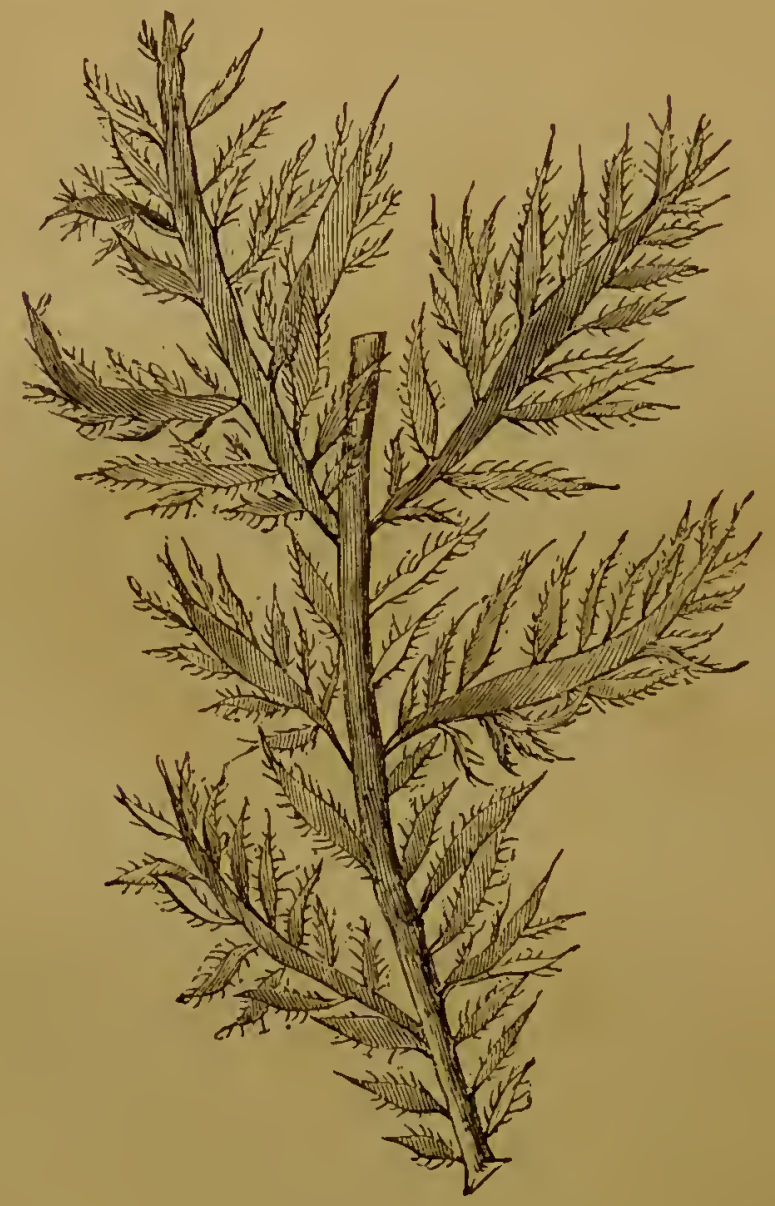

LIGULATE DESMARESTIA.

Perhaps more beautiful, but not more interesting than these kinds of Fucus, are the Ulvæ, those broad, flat, wrinkled edged, green sea-weeds, looking like halftransparent membranes. One of them, the Broad 
Ulva, has a small disc by way of a root, and grows from 6 to 20 inches in length and from 3 to I $_{2}$ in breadth, in tufts of different shapes. It is very common on all shores, on rocks and stones between tide-marks, and extends downwards to a depth of

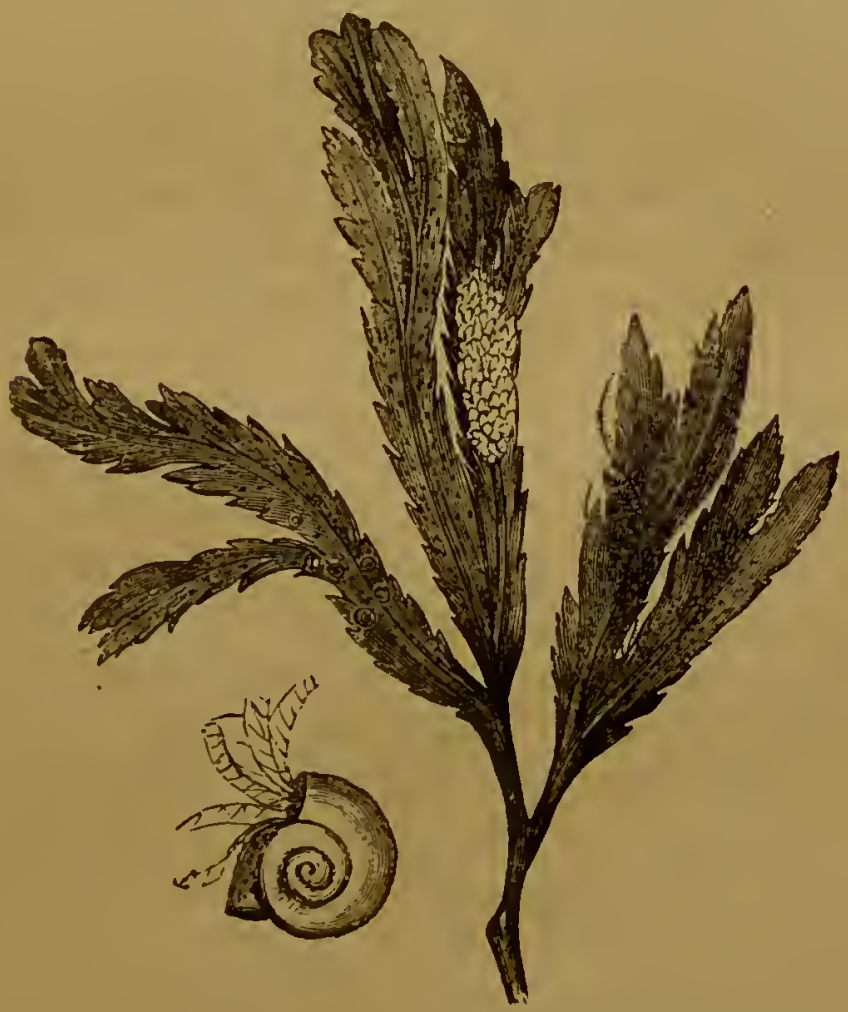

SAW-LEAVED FUCUS WITH SPIRORBIS.

ten fathoms. It has a wonderful geographical distribution, for, with the exception of the coldest regions of the globe, it inhabits every shore. It used to be eaten under the title of oyster green, being prepared like laver; and the Icelanders used to, and perhaps may still, ascribe an anodyne virtue to it. 
They bind it on the forehead in fevers, writes a Scottish botanist.

The other Ulva, which is nearly as common as this, is smaller, and grows in the form of an inflated bag, which opens and expands. It is of a very bright and yellowish green, and it is thinner and more delicate than the other kind. It is seldom seen except in spring or early summer, on rocks, stones, and shells between tide-marks, and it is generally distributed around our shores and those of Europe.

A very common green weed, found between tidemarks and also in ditches running into the sea, was supposed by its first describers to resemble an entrail or intestine; hence it has been called Enteromorpha intestinalis, from the Greek words, entcron, entrail, and morpha, form. It grows from a few inches to a foot or more in length, and from a line to three or four inches in diameter. Seen where it is attached to a stone, it is like a tube, hollow, meinbrane-like, and green; but further out it is larger and swells out into an irregular bag, crisped and curled here and there. It is very common all over the world, and finds its way sometimes into fresh water. The Rev. J. Pollexfen notices that it is prepared for culinary purposes by the Japanese for an ingredient in their soups.

The other common green Enteromorpha is called "the compressed." It is in the form of a branching green, delicate tube, flattened here and there ; and it clothes rocks between tide-marks, being sometimes as fine as a hair. It gets narrower at its attachment and is broad at the ends. Near high-water mark it forms a short, shaggy pile of slender fronds spreading over rocks 
and stones, and most treacherous to the stepping of unwary feet, being most slippery. A little lower down, in the rock-pools, it is larger, tubular, branched, and thin near the root; and where fresh water runs in close to it, the fronds get larger, broader, and more inflated. Almost everything green on floating timber or on stone, is this kind of weed. From being more or less tubular, these Enteromorphæ have a double green membrane. Now there is a beautiful ribbon-shaped Ulva which has this double formation and which is found at halftide level. It is long, even reaching to two feet, and is only half an inch to two inches broad. Very elegant and graceful are its tapering, curling, wrinkling, and plaiting of the edges; it is called Ulva linza, and is of a bright green colour. Amongst the commonest of the small green sea-weeds, are the Confervæ, hairylike green threads, which collect in layers and fleeces and cover much surface, or wave in the rock pools. One kind called the Sandy Conferva lives at half-tide level at Bantry Bay and also in Scotland at Appin. It-forms fleeces a yard or more in extent, made up of thin layers placed over each other, but so slightly connected that they may be separated like gauze, for some inches, without breaking. The hairs or filaments are five or six inches long and are rather rigid; they are very long-pointed, and consist of a delicate tube membrane which encloses a series of long cells. Another Conferva, found attached to other sea-weeds at Bantry Bay, Berwick, Frith of Forth, and Torquay, has its filaments forming densely interwoven layers which cling over their supporting plant. It is of a dark green colour. A third frequents salt pools by 
the edge of the sea and rocks at half-tide level. It is a very twisted thing, and forms crisped layers from a few inches to several feet thick, which closely adhere to the inequalities of the rock, or to the plants which grow on it. It is of a glossy brilliant green colour, and is called the Tortuous Conferva.

There is a pretty green hair-like plant which branches and gives off branchlets on one side more than on the other. It comes from a little group of stems on a stone, and forms a small stunted but very elegant bush, three or four inches high. This Cladophora lives in the purest and clearest sea-water only, and in rocky pools left by the tide near low-water mark. It is only got at low spring tides at Dingle and Dublin and it evidently likes the cool sea water, and darkness. A sea-weed called the Adherent Codium forms a velvet-like pile on the surface of rocks in the South-west of England near low-water mark, but it is rare. Sometimes the green velvetlooking film may be three feet across, and it consists of myriads of short cylindrical filaments with simple club-shaped hairs on them. It is soft and gelatinous, sticks to paper, and appears to grow slowly. Another Codium, called the Amphibious, has been mentioned already. It occupies a different position on the shore to the other. It frequents turf banks on the west of Ireland, in County Galway, where the bog touches the shore. It is a very mesh of entangled filaments, and it dries up to almost nothing in dry weather, and increases and grows again on the coming of the welcome tide, spray, or rain. There is also a large Codium with branches, which looks like a sponge. 
Barnacles and shells, living at low-water mark, in exposed situations on the western shores of Scotland and Ireland, Falmouth, and the Land's End, have a weed upon them of a purplish-brown colour like a "crop of threads" (Nemaleon) of from three to ten inches long. They are slender, solid, and divide in twos from a little expanded base. In some places it chooses particular positions, and in our Irish localities it grows in shallow pools on the granite rocks, and nowhere else.

A common weed, sometimes twenty inches in length, varies from pale yellow in shallow water, to dark purple in deeper places; it lives at half-tide level, and is made up of tubular fronds filled with watery gelatine. Its tube swells, here and there, and bends at the end in a curious manner. It is called, after a French naturalist, Dumontia. Another weed with a cylindrical stem has many branches, and has swellings at their origin like so many knots. These are airvessels and help to support the plant, which is rather leathery. It is found on the English and Irish shores, and is called the Bladder Chain-weed (Cystoseira). But the most elegant of the weeds with air-bladders is called the Sea Oak (Halidrys) and it is found commonly on rocks and stones in the sea, below half-tide level. The fronds are from one to four feet in length, and the branches bear numerous long pods with compartments in them, the whole looking like a mustardpod, and these are the air-chambers.

The waving, slender, long weed, so slimy to the touch, and which is so abundant on all our shores, - the dread of the bather when it forms submarine meadows, over mud flats-is called the Cord-weed 
(Corda flum). It is sometimes forty feet, and usually often from one to twenty feet, in length, and is not twice as thick as a bristle where it starts from a stone, tapering and clothed with delicate hair, getting wider in the middle, and slender and hairy at the top.

There are some remarkable sea-weeds, which certainly do not look like things belonging to the sea, but rather to the land, where lichens and fungi live on stones and trees. One often is called Rivularia, and is found on rocks, at half-tide level, on the southern shores of England, and in the south and west of Ireland. It encrusts the rocks, rising in short lobes, and it feels fleshy and firm. It begins with a globe-shaped substance, which sends forth raggedlooking pieces; and although it is so dense, the surface is covered with a close pile of exquisite filaments. Many a dark rock, otherwise perfectly barren at the end of summer, is clothed with the bright green patches of this singular weed. Another of these encrusting things is often as round as a half-crown, and looks like a lichen. It is leathery, and gets ragged and warty with age, and is of a coffee-brown colour. It is called Ralfsia, after Mr. Ralf. A third kind looks like a flat thin clot or stain of blood; hence its name Cruoria, from "cruor," blood. It forms a scum on the smooth, exposed rocks between tide-narks, and is especially abundant in the West of Ireland and Jersey. The patches are from one to three inches in diameter, and their edges are very clearly curved; they are brown and red, and the hairs or filaments of which they are composed are purplish red. It can be removed in flakes with a knife. 
It will be noticed further on in this chapter, that many sea-weeds are found upon others; and indeed some of the most beautiful kinds are thus parasitic upon larger ones. An instance of this occurs to one of the humble crust-like weeds which is found on pebbles at half-tide mark. So small is the parasite that a slight magnifying power is required to make it distinct, and then it is found to be made up of thousands of minute forked threads, each of which consists of several long cells, one placed before the other, and some of the cells are large and egg-shaped, and contain the seeds or spores. It is called the Myrionema, from two Greek words which mean numberless thread.

The next great group of sea-weeds to be noticed on the shore, has many more kinds below low-water mark, where they are never uncovered, than above. They are the great dark, olive-coloured, ribbonshaped, wavy-edged weeds, which have a tough skin and roots, which adhere to rocks, and which are called Tangles and Laminariæ by botanists. Their proper position, as a rule, is not on the shore, for they almost characterize a particular zone of depth; but there are kinds to be met with on rocks and timber, close to the low-water mark, and on the shore. Some of them are very remarkable when they are placed, as they are in the north of England, on the sea-beaten parts of white or gray rocks. They then often form a dense layer-a sort of black, moving fringe, which is sometimes uncovered. Most of them flourish in the most boisterous seas, and it would appear that those, which may, with some reason, be 
called shore-plants, because they are close to lowwater mark, and now and then uncovered, are smaller and more delicate. Thus one kind, which has been called the Weak, or the Papery Tangle (Laminaria fascia), has a stem not bigger than a bristle, which gradually widens into a frond about twelve inches long and two broad. It is greenish or brownisholive in colour, and is very fragile. It has the remarkable geographical distribution which is very common to all those weeds living on the brink of the sea, for it is found as far off as the Falkland Islands. On our coasts it covers sandy rocks and stones near low-water mark, and is to be found in the north of Ireland, the western islands of Scotland, and the south-west of England.

Another kind fringes precipitous rocks at low-water mark, and is abundant on the shores of Scotland and of the north and west of Ireland, the west and southwest coasts of England, and the north-east coast. Mr. Harvey notices it as one of the kind luxuriating in a furious sea, although its frond can be readily torn with the hand. It has a stem as thick as a quill, and a root of many branching fibres. The frond, or ribbon-shaped leaf, is from three to twenty feet in length, and only grows three to eight inches broad. It has a midrib running down its whole length, and the following peculiarities: there are many little leaflets on either side of the stem before it merges into the broad frond, and the surface is perforated with small pores, out of which come tufts of shred-like fibres. It seems to be an everlasting weed, and the first growth in the frond occurs from the stem. 
'The new parts are lighter-coloured than the old, and after a while, intersection takes place, where the new part joins the old, and the old leaf falls. This plant, from the side leaves giving it a winged appearance, is called the Alaria (from ala, a wing), and it is eaten in some parts of Scotland and Ireland. The midrib is the delicacy, but it is very insipid. 'The Scottish name is Badderlocks, or Henware, and the Irish, Murlins.

A most graceful and delicate Tangle is to be found on the south and east coasts of England, all round Scotland, and at Bantry Bay, Howth, Balbriggan, and Kingston, in Ireland, on rocks and stones in pools left by the tide. When fresh, it is a clear brown-olive in colour, and it changes to green when dry or when placed in fresh water. The leaf comes from a stalked root, tapers to the end, is frilled at the sides, and may be from six inches to three or more feet in length, and from one to six inches broad. It is thin, but is traversed by a double layer of large air-cells.

There is a large Tangle which goes by the name of Furbelows; and when spread out on the shore may make a circle of fronds twelve feet in diameter. It is a clear brown-olive in colour, and the root gives rise to a stem with large hollow knobs on it. The leaf is oblong, and is deeply split into many parts. The plant grows on rocks at low-water mark, and is abundant.

But the commonest of all these Tangles, with its long stem and branching roots, and beautiful, slippery, crumpled leaf, forms a belt, about low-water mark, round all our rocky shores, where its long, 
ribbon-like fronds wave gracefully in the water. When it is in deeper water it is much larger, and is then called the Broad-leaved Tangle. The great Tangles which are employed to form kelp, are not shore plants, but live covered with water.

The gems of the sea-shore are, however, not the olive and green weeds, but the red kinds, and they abound. There is a very large and handsome one, which is rare in deep, shady pools at extreme lowwater mark, but which is often washed up in storms, about the south-west coast of England, Bantry Bay, Antrim, Down, and Orkney. It is somewhat kidney-shaped, in the outlines of the large blood-red fronds, and has a stout, round stem. It is made up of three layers, and some plants are male, and others are female. This plant is called Kalymenia, from the Greek words that mean beautiful, and membrane. Another kind of the Kalymenia, found at Falmouth, Plymouth, and Bantry Bay, is something like a short, broad Tangle with crisped leaves in shape. It is red, and the root is a disc, and the fronds are about a foot in length. It is found on rocks and stones, within tide-marks, in land-locked bays. It is very thin and delicate, and may be compared with a totally different-feeling red seaweed, which has flat fronds of irregular shape, fringed with little leaflets, the whole being half-gristly to the touch, and of a dull purplish colour. It is common on the shores of the south and west of Ireland and Jersey. The root is very fibrous, and altogether it is a most peculiar weed. There is another of these leathery weeds which grows to some size, 
and has well-grown leaflets on its edges, besides large circular markings on its purple surface, which is pretty common everywhere. They belong to the genus Rhodymenia, so called from the Greek words red and membrane.

The last kind is the Dulse of the Scotch, and the Dillisk of the Irish. Mr. Harvey thus notices its edible peculiarities :- "In Ireland and Scotland this plant is inuch used by the poor as a relish for their food. It is commonly dried, in its unwashed state, and eaten raw, the flavour being brought out by long chewing. On many parts of the west of England, it forms the only addition to potatoes in the meals of the poorest class. The variety

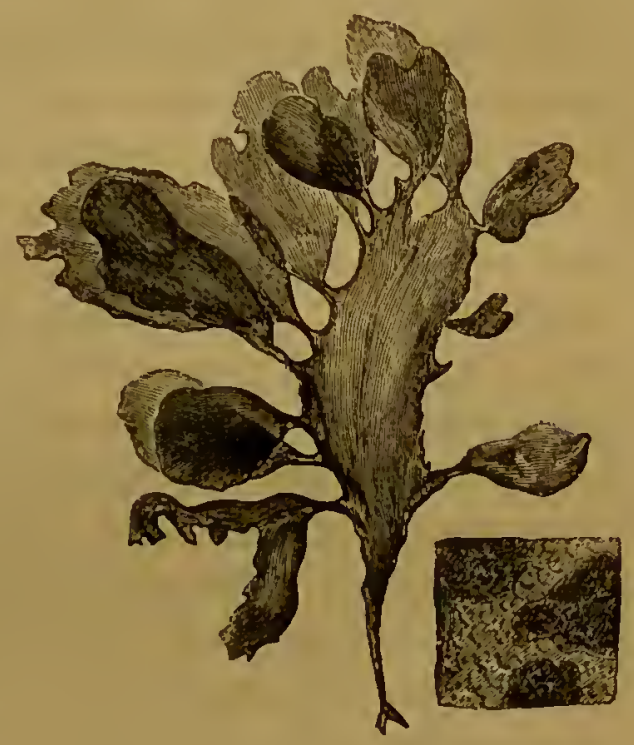

RHODIMENIA PALMATA. which grows on mussel shells between tide-marks is preferred, being less tough than other forms, and the minute mussel-shells and other small shell-fish which adhere to its folds, are nowise unpleasing to the consumers of this simple luxury, who rather seem to enjoy the additional sont imparted by the crunched mussels. In the Mediterranean this plant is used in a cooked form, 
entering into ragouts and made dishes; and it formed a chief ingredient in one of the soups recommended under the name of St. Patrick's Soup by M. Soyer to the starving Irish peasantry." It should be noticed that Dr. Harvey, to whom we are indebted for everything relating to the description of seaweeds in this little book on the shore, was keeper of the herbarium in the University of Dublin, and that he wrote in I 846 .

Another dark-red sea-weed, which is very iridescent when waving under water at low spring tides, is also said to be eaten in Cornwall, but, Harvey says, more by women than men. It is called the Edible Iridaa from its rainbow colours, and is about six inches in length, and it is gristly to the touch, and is rather like a battledore in shape.

The supposed luxury which is served at the tables of many, and which is called Laver in England, and Sloke, Sloak, or Sloukawn in Ireland, comes from some seaweeds which are delicately membranaceous, flat, and more or less purple. The colour gives the name Porphyra, from the Greek word "porphuros," purple. One kind is something like a large, crumpled lettuce-leaf in shape, without the veins and stalk, and the other, which is the commonest, has a long frond like a Tangle, of one or two feet long; but there is no long stalk. The edges are crisped, and the end of the frond is rather sharp and long. It is very thin, glossy, and more or less of a vivid purple. It is abundant on rocks and stones between tide-markis on our shores, and is an annual.

There is a handsome sea-weed called Nitophyllum 
punctatum, "a shining leaf." It is of a rose-red colour, and its membranaceous frond has its edge cleft ; it is veinless, or has irregular veins towards its base. The thin expansion is very delicate, and is characterized by the want of "nervures" or veins, and the presence of spots or tubercles immersed in it. These are large, oblong, and very general, and contain the spores. In other plants of the same kind the spots

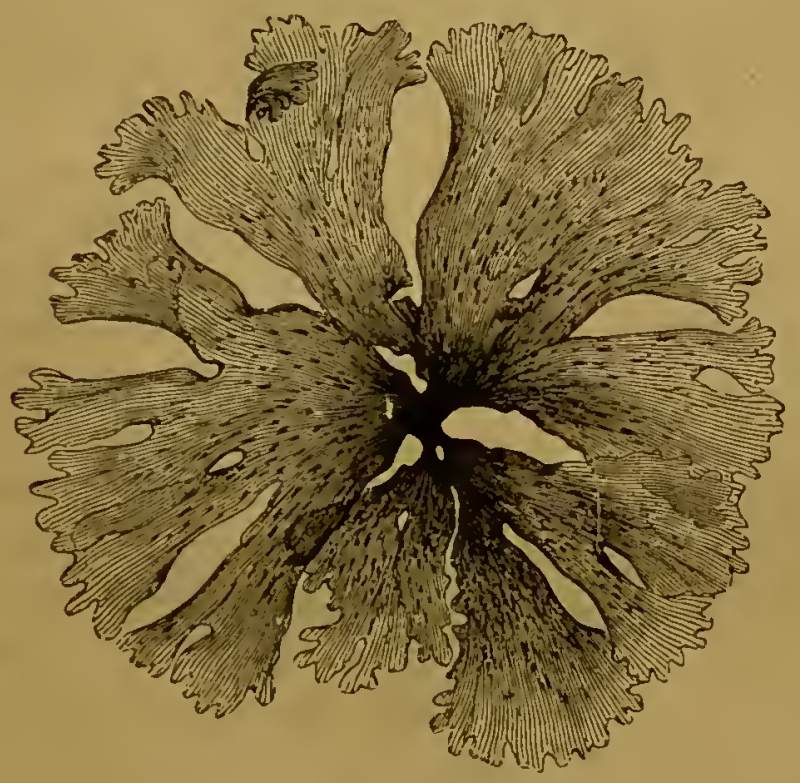

NITOPHYLLUM PUNC'AATUA.

contain tetraspores. The root is from a small disc, ${ }^{\prime}$ and the fronds grow in small tufts from I 2 to 20 inches in length. They are attached to other weeds at low-water mark; and are found on rocks down to fifteen fathoms. It is very abundant on the coast of Antrim, and all round the British coasts. 
A rose-red filamentous sea-weed being from two to six inches in height, with the stems not much thicker than bristles, their fronds being long, is found on rocks near low-water mark, and generally in deep pools from Orkney to Cornwall. It is called Griffithsia Corallina.

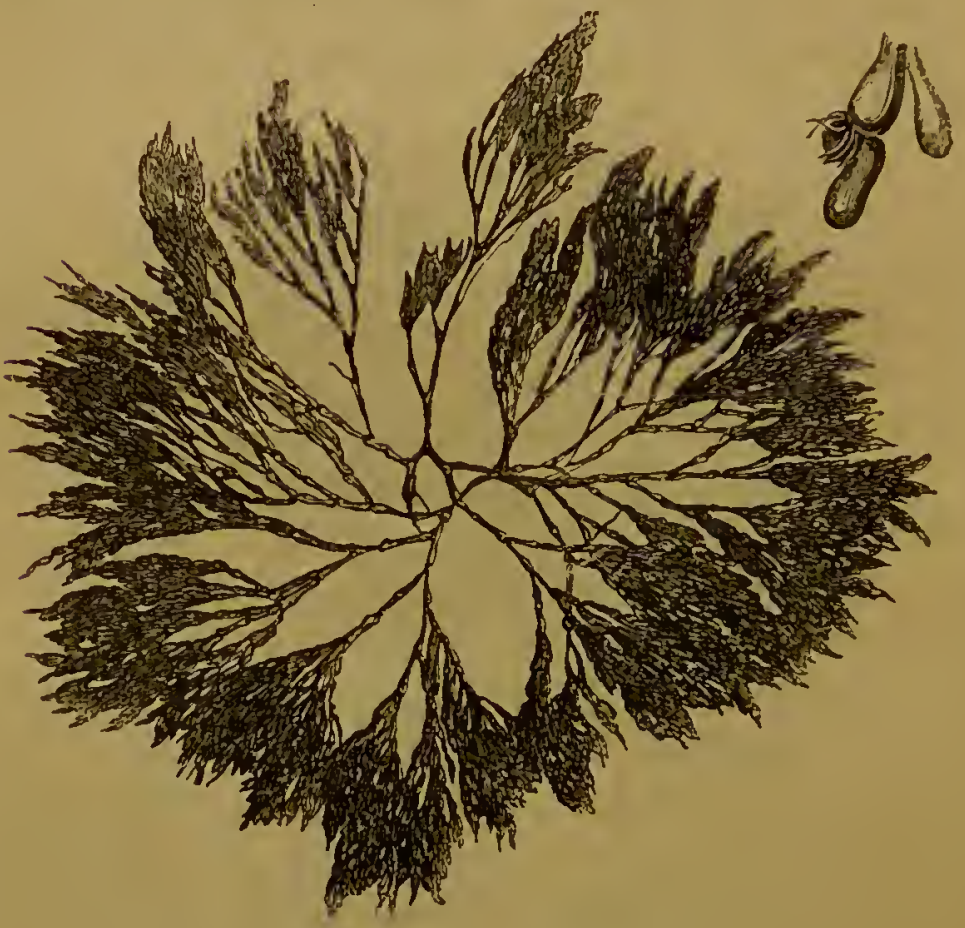

GRIFFITHSIA CORALLINA.

Other kinds of Rhodymenia are common on rocks and stones, or on the stems of the Tangles, near the very verge of low-water, or higher up. One found in the first situation is most common in the southwest of England, but is found everywhere on the British shores. It has a little disc for a root, and a 
long, slender stem, rather round near the root and flat above, where it gradually expands into a red membrane in the shape of a fan. But it is not whole, for it rather resembles a skeleton of a fan with notches at the edges, a dark spot being at their ends. The whole may be four inches long. The other kind is purplish, and the stem has branches, each of which ends in a ragged fan. It has little knobs on the side of the stem and on the membranous parts which bear the spores. It is sometimes called by another generic name, that of Leaf-bearer, or P.hyllophora.

A rose-red seaweed which has a midrib along all its thin branching fronds, and which is like a flat miniature bushy tree, is common all round our coasts, between tide-marks and more deeply. The tips of the fronds have little bodies on them which are whiter than the rest, and which contain peculiar spores, and there are also little knobs or tubercles which are attached to the midrib, and these contain another kind of spore. It belongs to a number of sea-weeds which have been named Delesseria, after Baron Delessert, a former distinguished botanist. Another, which is called Delesseria sanguinea, from its blood-red, or rather rosered colour, has a frond like a laurel-leaf, but it is crumpled at the edges. It is thin, has a midrib, and several spring from a stalk. Little fronds come from the midrib, in the middle of the larger fronds. It is one of the many weeds that fruit in winter-time, and it is to be found in deep rock-pools, between tidemarks, and generally at the shady side of the pool under projecting ledges of rock. It is a great 
favourite, and grows to a considerable size, the fronds reaching sometimes ten inches in length.

Perhaps the most beautiful of the red weeds is found on rocks, and on other sea-weeds, at low-water mark. It resembles a number of skeleton leaves on a stem dyed a fine red, for the frond is not a mem-

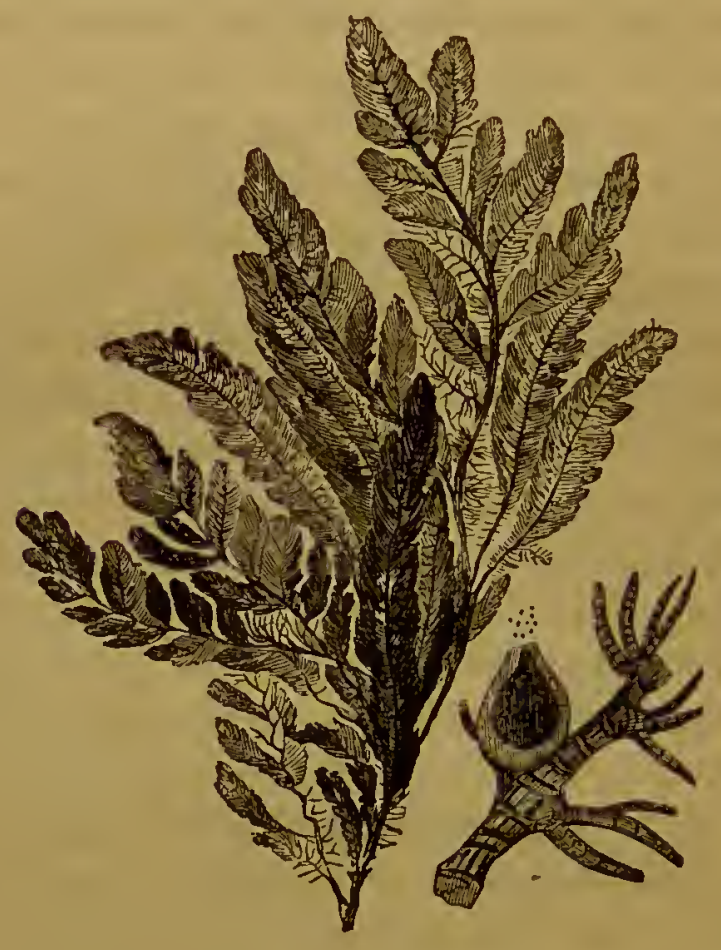

DASYA COCCINEA.

brane, but a number of branching threads or hairs, and it arises from a stem. It is from six to eight inches in length, and is named Dasya, from dasus, the Greek for hairy. It is much used for ornamental purposes in the collections of sea-weeds.

One of these dissected skeleton-leared sea-weeds 
is found on rocks and on other sea-weeds, near lowwater mark around our coasts. It is a tender and soft plant of a fine carmine colour, and it arises from a stem, which, after growing for a while, branches in twos. Then, side-twigs come off opposite each other, and one on either side of the stems and branches, and numerous hairy-looking projections arise from the upper edge of each of the twigs. Each hairy process has others on one side of it, and some of them bear. little bulbs which contain the spores. It is singularly regular in its growth, and as it is small, it looks well under low magnifying power. It is a pretty shrublike thing, and hence its name Beautiful little shrub, or Callithamion. Another Callithammion is that branching weed which is seen waving under water upon the stems and fronds of the Tangle. It is a robust and shrubby-looking weed, which, even when dry, retains some of its elegance of form. It is of a brownish-red colour, and when fresh water is added it becomes of a brilliant orange tint, and gives out a rose-coloured powder.

One of the many instances in which one kind of sea-weed is much more luxurious in growth on the Irish than on the British shore, is noticed in the case of a beautiful skeleton-looking, crisp, red weed called "Wrangelia," after a Swedish naturalist. Its fine stem has little whorls of fibrils one above the other, so that it presents a most strange resemblance to the common Horsetails of our marsh ground. Branclies come off from the whorls, which, horsetail fashion, have their bractlets on successive whorls. It has a root of fibres, and a good-sized specimen would 
cover a quarto page of paper. They are found on the steep sides of pools near low-water mark, under the shade of other sea-weeds, and they are to be picked on the south of England, Jersey, Belfast, and the west of Ireland.

The Braided-hair weed, Plocamium, from plokamos, braided hair, is the pinky-red, ribless, much-branched, rather gristly weed, which, from its elegant arborescence and beautiful colour, is an especial favourite with the workers in ornamental sea-weed decorations. It is cast up in quantities on all our shores; but as a rule it lives beyond the shore, that is to say, below low-tide level. Another equally common weed has a slightly darker red colour, and its frond is horny, flat, branching in twos, and with little fronds on the edges. It is found from the very verge of high water to the extreme of low water, fringing the margins of the rock-pools, and is very common. From its hard condition and horny nature it has been called Gelidium, from gelu, frost. The beautiful red weed, whose resemblance to a great branching tree pressed flat is so great, and which bears thousands of little berry-looking knobs on short stalks, on the sides of its fronds, is called Sphærococcus, or Globe-fruit or berry. It is not known on the eastern coast of Britain, but is common on the Irish shores at extreme low-water mark. Another red weed, with a dull purple colour, has a frond of from six inches to two feet in length, and every minute ramification of its skeleton-leaved frond has one or more berry-shaped swellings. It is common all round the coast within tide-marks, and has been called after a genus of mosses, Hypnaa. 
The last kinds of filamentous, or skeleton-leaved red weeds, to be noticed, are remarkable for their tufty nature, their spreading out in water and showing treelike branching from a stem, which, when magnified, is seen to be made up of many long cells placed side by side. Some live between tides on rocks, and others at the edge of low tide, but the most interesting are parasitic upon other weeds. From their many-tubed nature they are called Polysiphonia. The parasitic kind (so named) is rather rare, and settles on some of the calcareous weeds. The lanceolate kind is found on the stems and fronds of the Tangle; and a dark red species, called Formosa, is found near low-water mark. Brodie's Polysiphonia is known by the little tufts of branches which come from the main branches, and it has a good stem. It is found on corallines and on rocks.

The fibrous Polysiphonia has tufts at the end of its branches, and is found on mussel shells; and the violet kind is brownish-red or purple, has a small rootlike disc, and fronds which are from six to ten inches. in length. It is feathery and much branched.

It has been noticed that some sea-weeds are parasitic, or live on others, fixed certainly, but whether they get any nourishment through their roots is doubtful. One of these is very common on Fuci, the bladder one especially; and it occurs as dense little tufts on the leaves. These when examined, are found to be made up of long, flaccid, olive-coloured hair-like filaments, about an inch in length. They rise from a little hard spot, and form a tuft with a broad circular outline. They belong to a genus: 
60

THE SEA-SHORE,

called Elachista, from the Greek word for "the least." The hairy Ceramizum is a tufty weed, which is sometimes parasitic and sometimes not. It has a very peculiar shape, being made up of filaments placed

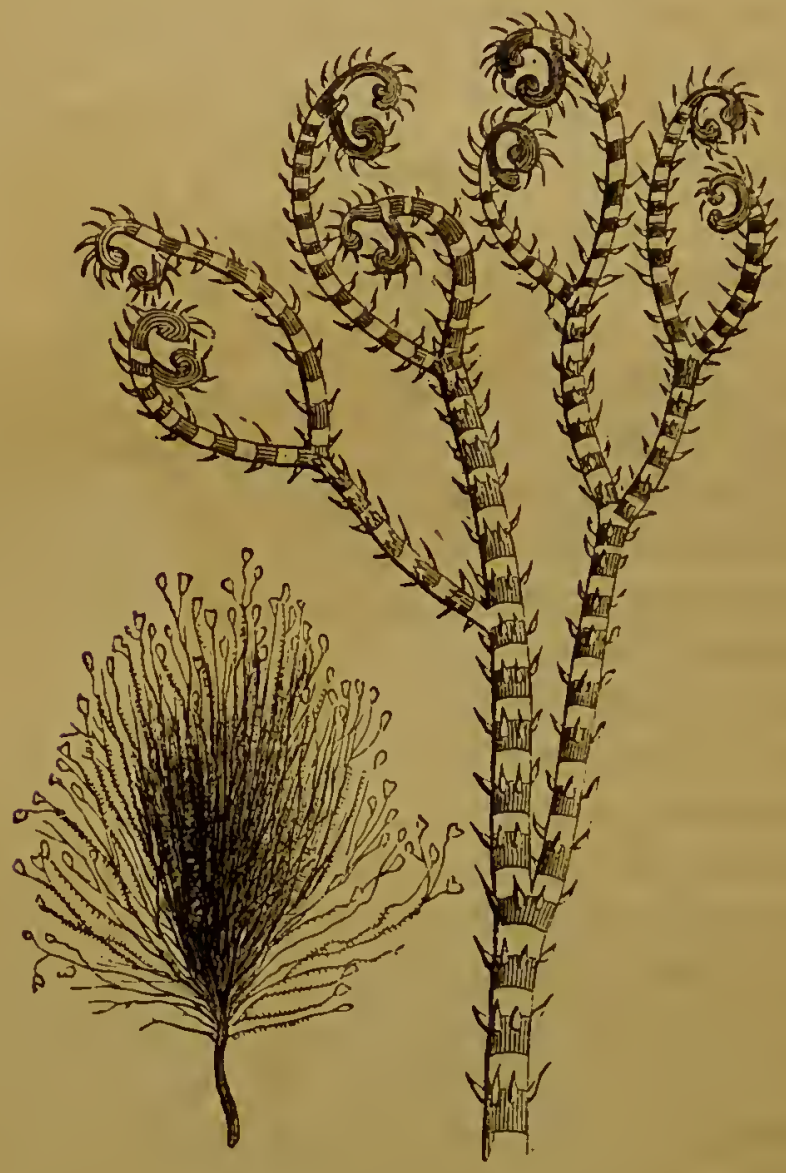

CERAMIUM CILIATUM.

side by side in great numbers, but they branch and rebranch, have little whorls of minute prickles along them, and the ends curl gracefully.

Amongst the more remarkable sea-weeds is the 
Carrageen, or Irish moss. It is a very variable plant in its colour and shape, and it may be a yellowishgreen, a livid purple, or of a brownish tint, and it may be in the shape of a wrinkled, crumpled fern, or of a bush. It has a root-stem, reaches a foot in height, and the largest are found in estuaries where mud comes down with fresh water. The weed is found abundantly on the shores of our islands, and formerly was used in the place of isinglass for making blancmange, an edible which has degenerated with the progress of imitative culinary art. It was a fashionable remedy for con.

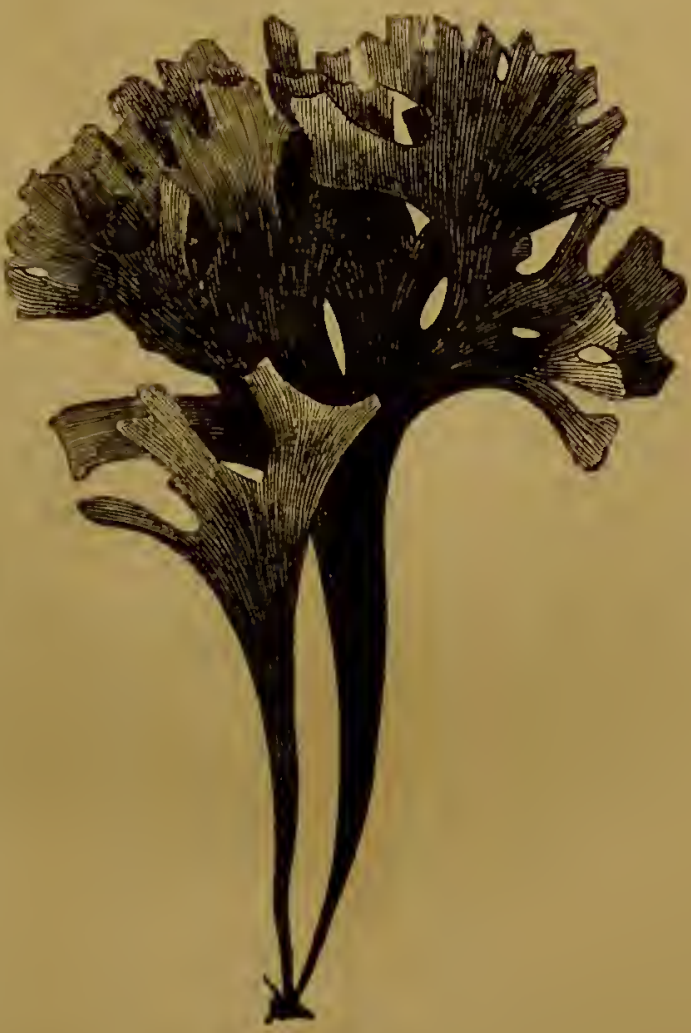

CARRAGEen moss (Chondrus crispus). sumption, and many of the peasantry of the west coast of Ireland used to collect it.

A most extraordinary fan-shaped sea-weed has a root covered with woolly filaments and fronds, from two to five inches in length, wide at the base, and 
expanding in almost perfect half-circles. The frond is curved, marked across, and has a disposition to form funnel-shaped pieces. A fringe of orangecoloured filaments is on the markings, and at the edge, which is often strongly rolled inwards. The outer surface is covered with a kind of whitish powder. The general colour is yellow and olive, with a dash of red. This Peacock-tail weed is found on

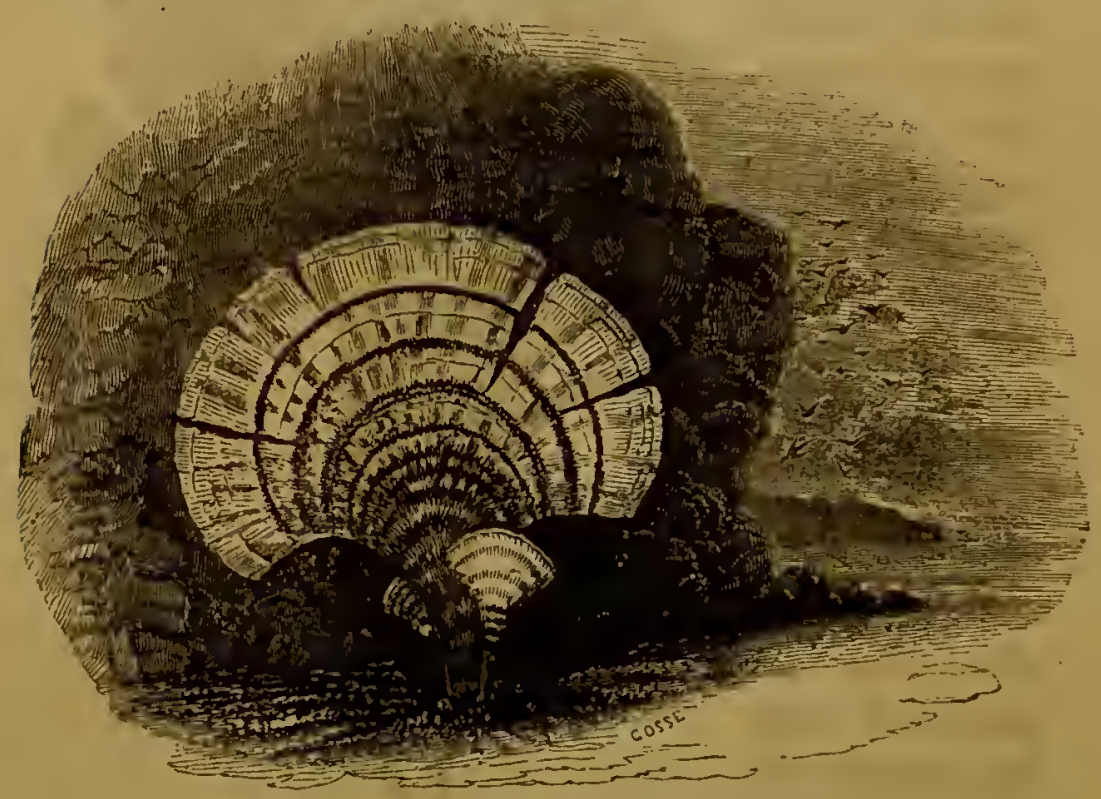

PEACOCK'S TAIL (Pedina pavonia).

rocks in shallow pools, on parts of the south coast, and is abundant at Torquay. It is remarkable for being an extension, northward, of a common tropical sea-iveed.

A very common plant is to be found, either growing in little tufts 'on the rocks at low-tide mark, or as a waif cast up by the waves, in bunches, near 
where the coast contains rocks or earths which have carbonate of lime in them. It is also a dweller in deeper water on the floor of the sea, and oftentimes it may be seen waving lightly in a rock-pool; but it does not look like a plant. There are no leafy fronds, and it does not resemble any other common sea-weed in outside appearance. It has a stony look, and is hard to the touch; it will stand a pinch, and although it may break into separate pieces, it can hardly be crushed by the finger and thumb. Usually, as seen by most people, it is of a glistening white colour, with some purple about it, and is made up of a number of

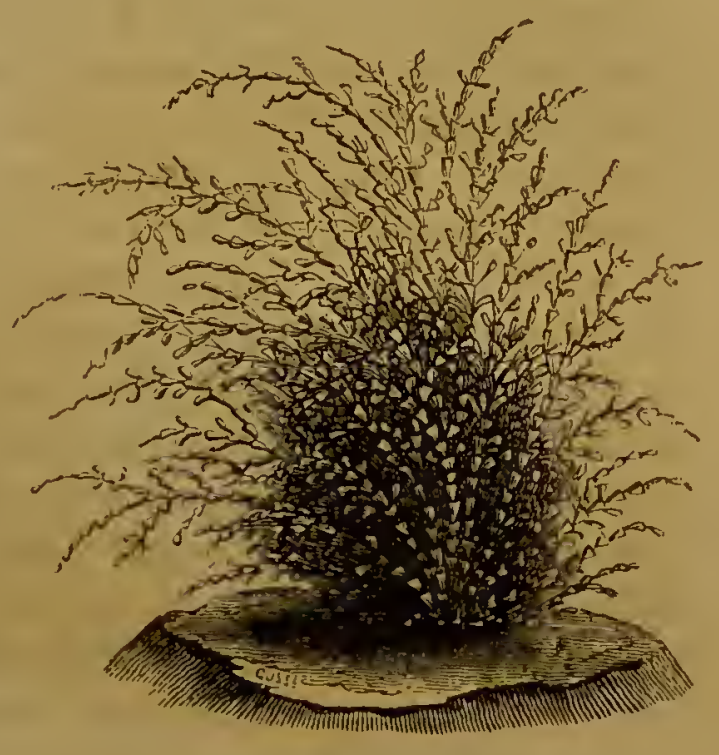

THE CORAI.LINE.

joints. The Coralline, for so it is called, has a sort of broad crust where it adheres to the rock, which gives out a stem. This stem is slender, and is made up of many pieces, placed one before the other, narrow where they join, and rather swollen in the middle or at the end. Other pieces, usually two, come off from the piece at the joint, and there may be hundreds of them or only a few. The 
end of the plant is made up of tufts of pieces, some of which have a little hole in the end, as if there were a hollow place. Now if the spots where the pieces join, be looked at carefully, there appears to be something like very thin threads uniting one piece to another, and they are not covered, as all the rest is, with the glistening white stuff, which feels gritty between the teetl. These Corallines, if placed in vinegar, begin to bubble as if they were made up of chalk, and their outsides are composed of a mineral called carbonate of lime. After a while the vinegar dissolves all the hard white part, and leaves the threads, which are now seen to run the whole length of the Coralline. These threads are portions of vegetable fibre, and constitute the inside stem as it were, which is surrounded by a sort -of bark of carbonate of lime. But this is only a popular manner of explaining, for if more care is taken, it will be found that, although some fibres run through more than one joint, others, when they are in the midst of a piece, turn outwards from the middle, and come near the surface where the carbonate of lime is. There they end in delicate bags or cells in rows, the last of which is quite at the surface; so that the outside of the pieces is made up of a mass of these small microscopic cells, and the rest of the long fibres. The older the plant, the more carbonate of lime is there in this mass of cells; but in very young plants, in the spring of the year, there is but little of the mineral, and they may sometimes be got quite soft. They are then short little stumps fixed on to the expanded root, which sticks on to stones, and they are not white, but of a 
beautiful claret or port-wine colour, the joints, where the fibres are, being greenish or without colour. This immature plant can be examined with the microscope, and then the secret of how the carbonate of lime is put in is divulged. First, it appears that any part of the young Coralline which is growing, does not have any of the opaque mineral in it, and that the fibres never have it in them, nor has a very delicate skin which covers the whole, and which is very difficult to get a sight of, for it is easily washed off. By putting a young piece in weak acid, bubbles come out, and every now and then one blows up this exquisitely thin pavement-looking film from off the surface. It is then seen to be made up of flat cells, placed side by side, and colourless. This is the important tissue by which the plant lives, for it exists long after all within is hard. It is always growing and being repaired; and in the tropics, where the water is warm, the little cells of it are covered with very long hairs, and, indeed, they may sometimes be traced in English specimens. Leaving these outside cells and the membrane for awhile, it is necessary to consider those beneath, and which are more or less connected with the long fibres of the joints. A row of these more deeply-seated cells is on the outside, just beneath the membrane, and other rows are deeper and deeper still, until the ends of the fibres are seen to end as it were in contact with the innermost. The outer row of all these is of a pale green colour, and gradually the port-wine tint comes with depth from the edge. Each of the cells of these rows is not quite covered with the hard mineral, and they communicate their fluid contents to another; 
and it is found that it is between the cells that the carbonate of lime is deposited, and which can be dissolved out by vinegar. As soon as a set of cells has done growing, the mineral is deposited, invests, and comes outside them, until it invades the delicate membranes of their bag as weil. How does this plant live? and where does it get its lime from? It does not absorb anything by its root, for it is placed on a stone, but all nourishment enters by the thin outside layer. In all sea-water there is some organic stuff or sea soup, the result of the decomposition of tiny things, and there is some air in the water which contains oxygen and nitrogen and carbonic acid. Under the influence of life, the organic stuff is absorbed by the cellmembrane, and is rendered useful to the rest of the plant, into whose cells, not quite walled up by carbonate of lime, it enters like sap, and circulates. The carbonate of lime can only get in, by there being some minute quantity in the sea-water, and there is sufficient in the chalky spots and limestone shores, not only dissolved by the sea-water, but held in suspension by it. The water is ever on the move, passing over the Coralline, and in a few weeks a few grains, for they make a great show, are absorbed and deposited in it. Small Sea-Snails browse on the Corallines, and have to thank them for their lime, which is necessary for their shell.

There are some other plants found at low-tide marks, which are calcareous, but instead of being jointed, like the Corallines, they form irregular and rounded little blocks, or simple papery-looking expansions on some of the larger-leaved sea-weeds. They are usually white 
and hard, and no one would consider them to be of a vegetable nature, were their microscopic anatomy not known. They have a great resemblance in mineral structure, to the Coralline, and are called Melobesia or Nullipores.

The sea-weeds are, as may have been gleaned from the last few pages, divisible into red, olive, or dark and green kinds, and one of their most interesting studies relates to the method of reproduction. Many seaweeds are annual and die in the winter, so they must be reproduced by seed, or something like it; others are of two or more years' growth, and outlive the winter, but in the end they must have some method of perpetuating their kind. Some are perennial, or constantly growing. Certain kinds are only found in the spring and summer, others are always to be met with, and some produce spores, or the matter out of which the future weed grows, in summer, and others in the autumn and winter. The geographical range of some of our sea-weeds is immense, and not a few kinds are found at the Antipodes. 


\section{CHAPTER III.}

The Microscopic Plants and Animals-Diatomacex-Animalcules and Spores-The Foraminifera-Sponges, and their Reproduction and Habits-The Shell-boring Sponge.

THE tide and rock pools which do not dry up, and which are not much swept by the waves, contain many microscopic beings, some of which are of exquisite beauty in shape and ornamentation. Many Diatomaceæ are to be found, often forming a yellowish layer on the rocks or on the sea-weeds, and their elegant and minute silicious cells can be collected and mounted for the microscope. They are found separate or in masses, and each individual, called a frustule, consists of two usually symmetrical portions or valves, comparable to those of a bivalve shell, which are in contact at their margins with an intermediate piece, the hoop, variable in breadth according to age. The separate valves are of various forms,-circular, oblong, elliptical, linear, saddle-shaped, boat-shaped, curved, sigmoid, \&c., and their flinty surface exhibits various more or less delicate sculpturings and markings, in the form of bands, lines, dots, and cells. The frustules are often surrounded by a transparent gelatinous sheath; and when they are removed from it, or when they are found free, they have a curious independent motion when seen under the microscope. They are usually classified amongst plants. 
Numerous microscopic animals belonging to the group of Infusoria are to be found in the pools; and Amœba, with its changing shape, may be obtained and be seen gliding or streaming along. Amcba, so common in some fresh-water ponds, is as transparent and full of granules and round bodies in the sea-water as elsewhere. It moves there, as in fresh water, by the peculiar rolling, spreading motion, and sending forth prominences and retracting them, whilst a streaming of the contents progresses in one direction. It is found also encysted or inert, and invested with a membrane, and if this is watched, numberless minute globes will be seen to be formed within. These burst forth, and each becomes an Amœba.

The commonest of the Infusoria is a very lively one, covered with moving cilia, and it may be seen twisting round and round with great rapidity, or rushing off suddenly, being followed with difficulty by the observer.

This Paramecium-like animalcule or infusorian ends like Amœba; for after being very active, it becomes stationary, and minute particles form in it out of its clear substance, and they are the future young. But many other minute things are to be found, and amongst them, at certain times of the year, crowds of little bodies with a more or less globe-shaped or bag-shaped body, with one or more minute moving hairs attached to one end. These whip-like hairs are always on the move, and take the spores, for such they are, from place to place. These moving spores have escaped from the sea-weeds and will turn eventually into those plants. 
There are not many kinds of those beautiful calcareous, almost microscopic bodies, which are called Foraminifera, to be found between tide-marks on the shore alive. Many are washed up dead from the deep, and collect along the sand in white lines, where the rough stone ceases and the fine sand begins. Our attention, however, can only be directed to those which are to be found alive on rocks in pools, or adhering to sea-weeds and stones, and they belong to two of the great divisions of this important order of the animal kingdom.

The first to be noticed has a shell composed of at least five parts, each overlapping its neighbour. It is rather flat, and there are three chambers, in which the animal matter is contained, on one side, and five on the other. The shell, when placed on its broadest surface, is elliptical, and there is an opening at one end where the shell overlaps. It is not, like those about to be noticed, perforated by minute pores through which threads of the animal matter or sarcode come out, like so many webs, but it belongs to the imperforate or porcellanous kinds. It is called Quinqueloculina seminula.

Another kind belongs to the perforate division of the order, and its discoidal shell is plano-conver, and adheres to weeds and stones by a flat face. The top of the shell is in lobes, like a nautilus shell somewhat, and is covered with minute holes for the sarcode web. This is called Truncatulina. lobatula, and it is a true rock-pool form. Living by catching prey with its projected web, which it contracts within the shell at pleasure, it captures minute 
prey containing carbonate of lime, and adds this to its skeleton or shell.

A Foraminifer with perhaps from thirteen to forty chambers, is rather flat or branching, and looks like a small ammonite; it is also perforated, and is called Rotalia. This has kinds within tide-marks. A kind of the genus Polystomella is also found; it belongs to the perforate group, and has a very pretty, free, regular, equal-sided spiral shell. There is a keel to it, and also numerous orifices which, are arranged along the edge of the last chamber. The last to be mentioned is called Nonionina, and greatly resembles a very minute ammonite, and it is like the last kind, but the openings are slit-like. It is covered with pores for the exit of the web. ${ }^{1}$

The Foraminifera belong to a group of animals next above the simplest. They are found after a little trouble, and the only thing that can be taken for them on the shore is a curled-up worm-case of the Spirorbis, so frequently found in the leaves of the serrate Fucus sea-weed (page 4I). This is milk-white, flat and spiral, and contains a little worm of the Amphitrite family (see Sea-Worms). On watching a live Foraminifer, its shell is noticed, in the perforate group, to be covered with gummy-looking stuff, which here and there projects a little and is withdrawn again. On placing one in weak acid and water, the shell will dissolve and leave the animal matter. This is found in parts or lobes, each of which was in a chamber, and

' The 'Micrographic Dictionary,' 3rd edition, contains plates and descriptions of these. 
the threads are offshoots of this simple flesh, called sarcode or protoplasm. The sarcode is granular, and it has motion, contraction, and can digest, grow, and multiply.

Anybody searching on the sea-shores of this country for a sponge, such as is used for washing with, would be disappointed and always laughed at. Even were a philosopher to go to most parts of the coast, and to make it known that he was seeking for sponges, wherewith to delight his eyes under the microscope, he would be looked upon with the ordinary pity which is readily extended to his class by the self-sufficient. We recollect some few years since getting into difficulties underneath an old wooden jetty on the sea-shore, whilst in a boat, the waves being troublesome and bumping going on, both to heads above and the bottom of the boat below. When it was understood that sponges were being looked for, our deserts were explained in characteristic English. On arriving on land, with sundry shreddy-looking dirty scum-like things in our hands, the demand was, "What have you got?" "Halichondriæ, of course; a sponge," was the reply, and it is not profitable to mention the unscientific reception of this interesting fact by the multitude. Small soft elastic bodies, often tinted with lively colours, but usually dull in tint, are to be found on the sides of large stones and rocks where they are exposed to the full force of the tide. When squeezed, they diminish in size and they have a porous appearance, some parts of them having prominences like so many large pimples. Others are flat and have not these projections, and they live under stones or around substances which 
are not exposed to much sea; whilst branched sponges are usually to be met with hanging down from sheltered rocks or niches of timber. Some, like the Spongia compressa, attach themselves to animals, such as Ascidians, and one in particular, Spongia coalita, can stand erect with its branches. The late Professor Grant experimented on this sponge, and the results of his investigations may be thus quoted :-

"In the month of November I put a small branch of the Spongia coalita, with a little sea-water, into a watch-glass, and placed it under the microscope; when, on reflecting the light of a candle up through the fluid, I soon perceived that there was some movement going on among the opaque particles floating through the water. On moving the watch-glass, so as to bring one of the apertures on the side of the sponge fully into view, I beheld, for the first time, the splendid spectacle it presented, a living fountain vomiting forth from a circular cavity an impetuous torrent of fluid, and hurling along in rapid succession opaque masses, which it strewed everywhere around. The beauty and novelty of such a scene in the animal kingdom long arrested my attention, but after twenty-five minutes of constant observation I was obliged to withdraw my eye, from fatigue, without having seen the torrent for one instant change its direction, or diminish in the slightest degree the rapidity of its course. I continuect to watch the same orifice, at short intervals, for five hours, sometimes observing it for a quarter of al hour at a time, but still the stream rolled on with a constant and equable velocity. About the end of this time, however, I observed the current beconze 
perceptibly more languid, the opaque flocculi which were thrown out with so much impetuosity at the beginning were now propelled to a shorter distance from the orifice, and fell to the bottom of the fluid within the sphere of vision, and in one hour more the current had entirely ceased."

Nothing is easier, writes Rymer Jones, than the repetition of the above interesting experiments. The entire surface of the sponge is seen to be perforated by innumerable pores and apertures, some exceedingly minute, opening on every part of its periphery; while others of larger dimensions are placed at intervals, and generally elevated upon prominent parts of the mass. Through the countless smaller orifices the surrounding water is continually sucked, as it were, into the interior of the spongy mass, and it as constantly flows out in continuous streams through the larger openings. Organized particles that everywhere abound in the water of the ocean are thus introduced on all sides, and are doubtless employed as nutriment, whilst the superfluous or effete matter is continually cast out with the issuing streams as they rush through the larger orifices. On examining a specimen of growing sponge during the months of October and November, a remarkable change may be observed to have taken place in its internal texture. The parts which in summer were transparent and nearly colourless, have now become everywhere studded with opaque yellow spots, visible to the naked eye and without any definite form, size, or distribution, save that they are most abundant in the deeper parts of the sponge, and are seldom observable at the surface. By examining 
these structures with the microscope at this period, it is found that these bright spots consist of groups of very minute gelatinous gemmules which lie imbedded in the soft substance. These yellow granules are the rudiments of the eggs or gemmules, of the sponge, and when they are first perceptible by the aid of a microscope, they consist only of a small, round, compact group of the same gelatinous-looking bodies which compose the living portion of the mass. But as they arrive at maturity they assume a regular form, and when mature are washed out of the body of the parent by the issuing currents, ready to become dispersed whenever the presence of the species may be made available for the beneficent purposes of nature.

On placing a few of the gemmules of a sponge above mentioned, which in size and shape might not inaptly be compared to minute pin's-heads, in a watchglass containing a little sea-water, it will soon become evident, even to the naked eye, that they are able to swim about with considerable facility, but how they manage to accomplish such a feat is by no means so easily discernible. On examining them, however, with a good microscope, the machinery employed for the purpose becomes revealed to sight, and certainly a spectacle more wonderful imagination scarcely could conceive. Millions of paddles, furiously at work, bestud the surface of these tiny atoms, so rapid in their motion that the eye almost refuses to perceive their shape; so manageable, that their action seems directed by one impulse, and yet so minute, that words in vain attempt to tell their almost imperceptible dimensions. The word cilia, whereby these structures 
are now universally designated, is derived from their resemblance to rows of eye-lashes (cilium, an eye-lash), but the most rapid wink will not express the quickness of their motion.

Some sponges are horny, like the common washing kind, whose curious skeleton we use on account of its taking up water within its meshes; others have the spiculæ, of which mention has been made, and have, or have not, also, a horny skeleton. The spiculæ in this instance are beautiful objects under the microscope, and are of transparent flint. Arranged in crosses, fours, and sixes, they may be like needles, or have knobs at the end. They may be grapnel or anchorshaped, and nearly every kind of sponge has differentshaped spiculæ. They keep up and sustain the soft tissue, covered with the cilia, and are produced by the animal out of its food. Again, some sponges have the spiculæe of carbonate of lime.

On looking at a common washing-sponge two sets of openings are seen on its surface, one large and many: more small, and the water currents enter into the sponge by the smaller pores, or little mouths, and come forth by the large ones. There is a circulation within the sponge. The small pores open into canals, which lead to larger ones, and these to other canals that at last open into a main river, which is continued to one of the larger openings. The water enters, and follows that course. Now the moving hairs, or cilia, are especially numerous in the larger canals, and a considerable current is made there, setting into the sponge, consequently water rushes in by the small pores, and out by the large. The whole of the horny 
and other skeleton is covered with a fine layer of the cilia-bearing cells, and they are very remarkable. Each one is somewhat in the shape of a flask, and is attached by its broad end to the skeleton. The other end has a long, thin, whip-like cilium, and where it joins the flask there is a kind of structure like a broad band, which encircles the stem with a collar. Before these cells arrive at this perfection, and indeed, most probably if any get cast loose, they can act as independent animals. They can crawl, change their shape, and expand and contract, and anything nourishing coming in contact with them enters in and is digested. This digestion goes on when they are in their proper place in the sponge, and every watercurrent brings in victims, whose undigested parts are cast forth with the outward stream.

Almost every large old oyster-shell is studded with numbers of small round holes, less than a tenth of an inch in breadth. They are the openings of passages going right into the shell, and they were made by a small sponge. It is not a bad plan to take a sharp nail or a gimlet, and to try and make a neat circular opening in an oyster-shell, which shall lead to a cylindrical penetration of the same breadth. What man cannot do in this manner, a soft sponge does during its process of growth. If the oyster-shell be taken to a lapidary, and he is told to cut it very thin, and to polish a piece, so that it shall be quite transparent, the presence of vast numbers of very minute tubes, many thousands of which in some parts of the shell would go to an inch, becomes evident to the eye under a good microscope. To make such 
long-winding, branching tiny tubes is quite beyond the art of man, yet they are easily produced during the growth of a plant belonging to the Fungi, which is so delicate that it bends with its own weight, and requires a lens to be made visible. The sponge and the plant destroy shells of many kinds by their perforations and penetrations ; and it would appear, that although they are very different in size and in construction, and that one belongs to the animal, and the other to the vegetable kingdom, the work they do is performed very much in the same manner. The sponge retreats within the hole in the shell on the least shaking or exposure to violence; but usually a little pimple, about a line in height and breadth, of a yellowish colour, projects beyond the shell. It is either closed or open, and when the shell has been placed in seawater for a time, and the surroundings have all been quiet, the yellow pimple appears to have an opening in its centre, and a rapid current of water continually issues from it. On touching it with a needle, the opening closes, the current ceases, and the body withdraws. The pimples when contracted have a rounded short extremity, but when they begin to advance beyond the surface of the shell, they become flat and slightly dilated, and take on a hairy look, with open fissures radiating from the centre to the margin of the pimple, and a circular opening is seen in the centre of the hairy surface.

The substance of this sponge, which is called Cliona (kleio, to shut), consists of soft, granular, greenishyellow protoplasm, no harder than setting strong gum and water, and it completely fills up the cavities in 
which it lives. It is traversed and covered with myriads of spiculæ, which are slender cylindrical tubes, slightly curved, acutely pointed at one end, and terminated by a small, hollow, round head at the other. The spicula of the Cliona are of flint, and are transparent, and they are not placed in contact with any muscular fibres, nor is the sponge stuff sufficiently dense to afford them a support against very slight pressure. It is necessary to mention this, because some people believe that the sponge works its spiculæ in such a manner as to drill the holes and tubes in which it is found. The oyster is hard, and a corresponding amount of force is required to penetrate it if direct violence is to be employed, and this is not possible to the soft Cliona. Both the fungus and the sponge dissolve the shell as they grow in, by the carbonic acid gas which they evolve. 


\section{CHAPTER IV.}

The Jelly-fish and other Hydrozoa-Planula and Hydra tubaSertularian or Garland Polypes-Plumularia-Hydractinia -Budding Jelly-fish-The Sarsia-Campanularian Polypes - Lamp Hydrozoa or Lucernarians.

IF anybody were asked to name the commonest objects on a sandy or pebbly séa-shore, the reply would be, -sea-weed, crabs, limpets, a stranded jelly-fish, looking like so much blubber, and a sea-gull flying overhead. The first three things really belong to the shore; the bird is a visitor, that is looking after food, and the large, turned-upside-down, basin-shaped, jelly-looking mass is a waif from the ocean. It hardly, then, comes within the scope of a book on the animals and plants of the sea-shore; but as a matter of fact, although a cast-a-shore from the sea, the jelly-fish may have, by this accident, returned to the neighbourhood where it was born and where it spent some weeks of its early life. If one of these stranded jellyfish is looked at, as it lies on the sand, its shape appears to be something like that of an umbrella without the stick. It is thick, however, and has some curious markings about its surface and inside. Even something like a fringe of thick hairs may be detected around the edge. On trying to take it up or turn it over, the fingers go into it, so readily does the animal 
tear; but on getting the umbrella on its back, the underneath part is seen to be made up, in the middle, of some projections slightly more solid than the rest of the body; and if put between them, the finger passes through a sort of tube into a cavity in the body, which is the stomach.

Some of these jelly-fish, or Medusa, as they are called, are pounds in weight; but after a while only a shred of membrane-looking stuff remains, the water which makes up nearly all the animal having drained away. Get into a boat in the summertime in a tidle-way, or look down into the depths of the sea from a jetty, and white-bluish, semitransparent, umbrella-shaped things may be seen moving along, marked with four red or white circles, like eyes, and having all around them a delicate long fringe of transparent hairs. They are never still, but seem to wave the edge of their umbrella-shaped body, expanding and contracting it, with a slight jerk someimes, and evidently moving in the water by the force of this change of figure. Sometimes they sink down out of sight, and some may be seen emerging into view from the depths. Hour after hour they pass by, and day after day, looking ghost-like, ever on the wander, never seeming to touch each other, or to chase or catch anything. Dip a bucket in the sea and turn the water into a glass vessel, and some tiny jelly-fish will often be seen, some resembling the large ones, but others are quite different. It is evident that the large Medusæe grow from small ones, and that there are many kinds of them, some of which are always small. A great jelly-fish, 2 feet across, was 
once a little one, leading exactly the same life. They grow, and to grow they must have nourishment ; they are never still, and their muscles, transparent as they may be, have to be nourished, or their strength would soon give way. If the water which contains several small living jelly-fish be not changed often, or plenty of air is not forced into it, they will die. They require not only food, but also air in the water, so that they consume it, and make its oxygen gas of use to them. They seek the light in a remarkable manner, and get out of the way of things very gracefully, and their motions are rhythmical, like the ticks of a clock, in succession. Have they nerves and eyes? Science answers in the affirmative. These creatures, consisting of a vast proportion of sea-water, breathe, digest, and feed. More than this, they produce young; and if they are pale in colour, bluish, or roseate in hue during the day, they are the glory of the deep during the night; and each one is a globe of light, the luminousness being the result of the action of the mysterious energy of life upon matter.

Many of the jelly-fish found on the shores dead and injured, are 18 inches across, and it is not uncommon to see one swimming freely, whose body is larger than that. Yet in spite of this size, and of the gifts of the creature, it has one of the shortest of lives, and it is born, grown, and dead between the spring and the winter. A great amount of overwrought sensational writing has been added to the natural history of these Medusæ. Thus the large jelly-fish of our seas, in the North particularly, is called the Hairy Cyanea, and it has four long pendent bodies 
hanging below the body of its umbrella, besides very visible hairs or tentacles on the edge. It has been written of it by a very celebrated naturalist, "Among them the Cyanea of our seas is a most formidable creature, and the terror of tender-skinned bathers. With its broad, tawny, festooned, and scalloped disc often a full foot or more across, it flaps its way through the yielding waters and drags after it a long train of ribands with arms and seemingly interminable tails. Once entangled in its trailing hair, the unfortunate who has recklessly ventured across the'monster's path too soon writhes in prickly torture. Every struggle but binds the poisonous threads more firmly round his body, and there is no escape ; for when the winder of the fatal net finds his course impeded by the terrified human wrestling in its coils, he, seeking no combat with the monster-biped, casts loose his envenomed arms, and swims away. The amputated weapons, severed from their parent body, vent vengeance on the cause of their destruction, and sting as fiercely as if their original proprietor itself gave the word of attack." If the word "human "were replaced by "shrimp" this very inflated paragraph would be nearer the truth, for all that can be said, so far as humanity is concerned, is, that people with excessively tender skins feel a slight sensation of stinging, not, however, to be compared with that of a nettle, if they are bathing, and come across one of these jelly-fish. The point of interest is that stinging is felt, and that small animals are killed by it or rendered motionless and liable to be got into the creature's mouth. 
On examining a large jelly-fish, which one may do without the terrific consequences stated above, it will be noticed to have not only four round bodies on the top, round the centre, and the four lobes hanging down beneath, but that the edges of the body are not quite round, but are notched, so as to make eight lobes to it. And if a little care be taken, marks can be seen on the under part of the body, from the round centre spots to each of the eight splits in the disc; and a magnifying-glass shows a little substance there which feels gritty, and is sometimes coloured. Other branching tube-marks pass from the midst of the body to the edge of the umbrella, and a tube runs all round the edge. The tubes communicate in the midst of the body with a cavity, into which the finger can pass between the four under lobes - the stomach-and the digested matters pass into them to nourish the creature. Around the disc or umbrella, and outside the circular tube, is the fringe of hairs which have, to a certain extent, to do with the capture of prey. Each consists of a filmy substance, in which are fixed thread-cells, not very unlike those of the sea-anemone, but they have longer barbs and sharper thorns stretching out from them. (See page I23.) Any violence or irritation causes the thread to shoot forth and to injure. The rest of the body of the Medusa is covered with an excessively thin skin, which has movable cilia upon it. It is supposed, and with some reason, for nervous threads and bodies have been found on the disc, close to the gritty bodies especially, that these last are eyes, or ears, or both. The nerves supply the muscles that move the umbrella, and cause it to ex- 
pand and contract, and the muscles are remarkable, for some are not simple contracting fibres all made of one piece, as in the Anemone tribe. When they are examined under a microscope, it is found that they are broken up into myriads of minute rods placed side by side, and attached end by end, a dark stripe appearing between each connection. It is the appearance yielded by the striped muscles of all animals which can move by the influence of the will.

The jelly-fish, when in full vigour and weighing many pounds, must catch and eat much, and the manner in which this is done is by no means perfectly understood. Probably no absolute catch is made of food, but it comes by chance to the mouth; and it will be noticed by any person who rows in a boat in midsummer in a tide-way where there are jelly-fish, that thousands of minute things float in the water, and are suitable for the food of those watery creatures. They have food and to spare, for a very pretty shrimp with a splendidly-coloured eye, lives under the umbrella of a Medusa, and participates in its food, being a parasite. The food is digested, and the results are taken from the stomach into the numerous tubes in the body, where they nourish the tissues. The movements of the animal and its extremely delicate membranes enable much water to come in contact with it, and it breathes by that means, for there are no special gills or lungs.

The four round spots on the top of the body, sometimes white and sometimes red in colour, are spaces in the body, and they open into the central stomach. The circles of these chambers are lined 
with cilia membrane, and in some places it is arranged in folds, and in them the eggs or ova form. Little oval or roundish things, like pins' heads are they: they burst forth and pass out of the stomach, and then through the canal into the four lobes hanging down like pouting lips. Here they rest awhile until a little grown, and they start out on their journey of life in the autumn time as little oval or long things made up of cells, the outside ones having movable hairs also on them. Totally unlike the parent, the tiny offspring floats off with the tide and does a little work in moving itself with its hairy covering. Sooner or later this minute thing, which is called a planula, settles on a stone or piece of sea-weed, and begins to grow. First of all its outer skin is formed into a hollow on the top, a kind of basin-shaped cavity being produced. This is the future stomach. Then some little projections grow around the hollow, and stick out in the water like so many rays, and they increase in number and length very rapidly. Under this shape the creature has been described as a hydra or a polype, and it really resembles a small sea-anemone with very long and slender tentacles. But the internal anatomy differs. The creature is all stomach and tentacles, and it grows by catching small prey. All the elaborate tissues of the jelly-fish are absent, and the creature cannot move. It is this curious condition of life that brings the jelly-fish tribe within notice of a seashore observer, for those little hydras live in some places at low-water mark. The knowledge that the hydra was the child of the jelly-fish was obtained many years ago by a Scotch and by a Scandinavian 
naturalist. It was known that some small kinds of jelly-fish which were kept in sea-water in an aquarium disappeared altogether in the late autumn. Then it was noticed that there were many very small things with tentacles, on the sides of the glass, which had not been noticed before. And at last the curious discovery was made, that these hydras or planulas reproduced jelly-fish the next year. In fact, if the hydras are placed under circunistances favourable for observation, in large glass jars, they will be seen to grow long in the body, and to have many constrictions in their tube-like shape. So many waists, as it, were. In the course of a few days the portions between the waists become marked with eight lobes, and they begin to look like so many saucers placed one over the other, as on a tea-table. At last some tentacles or feelers grow on the last saucer-looking piece near the attachment of the creature to the stone or glass, and all the rest break off, separate, turn upside down, and then resemble the tiny umbrellas of jelly-fish. In time they grow, the stomach is formed, then the hairs around the edge, and then the rest of the body, so that a perfect jelly-fish is formed. This is a very strange story, and the course of nature's proceeding is, that when food has become scarce and the boisterous waves would become fatal to the delicate Medusa, it shall lay eggs which produce creatures that can settle down out of the way of the rush of water, and that require but little food. Then in the next year when food is in plenty, the progeny separate into jelly-fish like the parent. The hydras or progeny have no power of laying eggs; they digest and produce 
the creature that shall lay eggs. The Scandinavian naturalists and Germans called this "alternate generation," and named the hydra the nurse of the jellyfishes. This is the method by which most of the jelly-fish, which may be occasionally seen stranded on the coast, were produced; but there are some whose planulas do not settle down, but are always free swimmers, and they divide into Medusæ in the sea.

This intensely-interesting course of life is modified in all the hundreds of kinds of creatures which are connected with the jelly-fish in classification, by their having many structures in common. The creatures thus classified with the jelly-fish are called Hydrozoa, or Water Animals, and they pass two lives, one of which is commonly observed on the sea-shore everywhere. One life is a fixed one, and the other is a free swimming one ; in one stage it is eating and drinking, and in the other, these functions are not always or often carried out. The egg-laying and perpetuation of the animal are the duty of the greater part of the beautiful branched and hair-like things which are arranged by visitors to the sea-side in patterns, and retained as memorials of pleasant days, and which are popularly called sea-weeds. They are not such things, but are the delicate stems, branches, and bud-like homes of the parents of tiny jelly-fish which are only to be caught in the open sea. These horny stems and branches end in creatures with tentacles or feelers, and they live between tides, in rock pools, and at low water.

Sometimes these fragile, plant-looking things are fixed on to stones or sea-weed, and some get a ride by 
growing on shells, inhabited, since the death of their original possessor, by the Hermit Crab.

One very numerous tribe of these feathery-looking weeds, but which are truly animals, is common every-

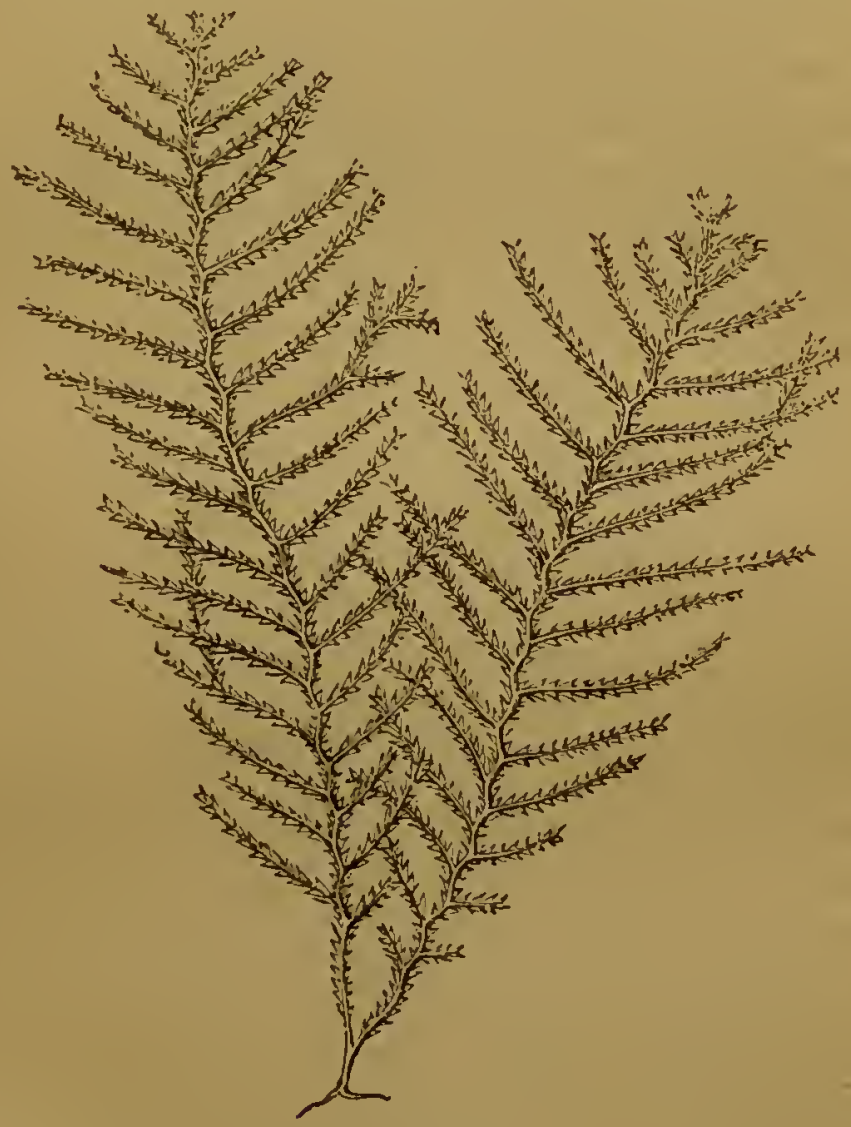

SEA-FIR.

where on the shore, between tide-marks into deep water. Their stems are branching, and the little budlike things on them, when watched in still water, may be seen to put forth pretty coloured bodies with tentacles around a centre; and as there may be hundreds 
of them on the branches and stem, the creature resembles a bunch of rayed flowers. Hence the name Sertularia, from sertula, a small garland.

These Sertularians were noticed and drawn many years ago, and were called Corallines. This is a great mistake, because the Coralline is a plant covered with carbonate of lime. The correct name would be the Garland polypes, and that term will be employed in this chapter. When we get a bunch of these creatures from the seaside they are dead, and the hard and preservable outside parts alone are left, all the beauty of colour and the wonderful inside structure are gone. But even then it can be noticed, that the stems of the creature arise from a network of tubes fixed on to stones, sea-weeds, and shells. This resembles a root, but it does not absorb nourishment like the root of a plant. The stems, often not bigger than hairs, are hollow, and the branches also. The surface of the branches is covered on one, or often on both sides, by minute cups. These give almost a sawedge look to it, in some of the creatures; and amongst these cups, which are open at their free end, are some larger ones, which are closed where free, and often ribbed and ornamented on their outside. It is noticed that the hollow of the stem and branches is continued into the cups, but not into the closed ones, and that these are shut off from it by a very delicate layer of tissue. This is the minute structure of these things when dead; but when alive, the inside of the sten and branches is filled with a soft substance, which reaches up to the part where each of the cups is attached to the outside. The cups, hundreds in number, 
on each stem and branch, contain a most beautiful flower-like polype. Variously coloured, according to the kind, it has a bell shape, and has a spot for the mouth, which leads to a stomach, whose floor is connected with the pith of the whole branch. Around the mouth are numerous tentacles excessively irritable, capable of stinging and paralyzing prey; and the spectacle of hosts of these, all working for the common good of the branching animal, is very beautiful. Sometimes there is much red in the colour, at other times green, yellow, or a dull tint; and in order to. relieve the sameness of outline presented by thousands of cups, their horny margin is spined or toothed. In full vigour during the summer, and living through the winter and probably for several years, these cups with their tentacled polypes contribute to the growth and nutrition of the whole. They all work for a common end, and that is for the persistence of the life of the colony. They live on microscopic things in the water, such as minute ova, or the young of things like unto themselves, and on animalcules, and probably on the moving spores of sea-weeds. As the spring advances, the larger and closed cups begin to grow by budding from the stem, and they become filled with a gummy substance with a few granules in it, and somewhat resembling the pith of the stem. As the closed cup grows, it often becomes. marked on the outside, with rings or belts, and it becomes a very prominent object on the horny-looking Garland polype. These closed cups are concerned in the reproduction of the creature, for after a few weeks, the substance inside them is seen to collect 
into bunches of round or oval bodies, often yellow in colour, or of other tints. By-and-by the cup bursts, or a sort of trap-door opens at the top, and these things escape. They are small, covered with cilia, or moving hairs, and resemble the planulas of the jellyfish in shape, and they swim freely, and finally settle down on a stone or weed. They become environed by: a horny coat, the stomach having been formed first by simple bending in of the outside of the creature, and tentacles grow. The planula thus founds a new colony. But there are other phases in this curious lifestory; for instead of the little round balls in the closed cups getting free as planulas, some in certain kinds grow there, and resemble excessively minute jelly-fish stuck fast by the back, and exposing the mouth, feet, and the fringed umbrella. These Medusæ, as they may be called, die on the parent, and never wander.

There is one kind of these Garland Polypes called Lafoa, in which the round bodies produced in the closed cups burst forth, and not in the shape of planulas. They come forth like tiny bells, furnished with minute eye-spots on the edge, and they have an umbrella shape, and long tentacles arising from the edge near the eye-spots. They are jelly-fish, to all intents and purposes, and swim freely about, and in time produce planulas which develop into a parent Garland polype again.

There is something very curious about the great irritability of these Garland polypes, for the least orerirritation of the delicate tentacles of the cups, produces their instant collapse, and they and the little body 
withdraw snugly into the bottom of their cup. 'This will go on whilst the others on the same branch are hard at work and well expanded; but too rude a shake will cause all to withdraw, and they will not come out again until things are quiet. The tentacles carry many threads or stinging cells. The great naturalist Sir John Dalzell showed that although there is this great amount of irritability, the parent stem may be treated very roughly. He cut some off by their roots, and cut the stems in pieces, and to his astonishment the pith grew out and formed polypes at both ends, and they then became so many new individuals.

There are a great many kinds of these Garland polypes around our coasts, and most of them have been described when dead, so that the shape of the stems, branches, and the ornaments of the horny cups have been used to distinguish them. Dr. Johnston mentions several which are really dwellers on the shore and not in deep water. Thus the "Great-tooth Coralline," or Garland polype, is found as a dweller upon others; and another, named after a naturalist who once lived in Belfast, Mr. Templeton, is found on Zostera leaves in shallow water in the loch of that locality. The Trefoil Coralline, another Garland polype, is found on sea-weeds and sea-mats at lowwater mark on the south-eastern coasts, as well as on the north-eastern and Scottish shores. The Pomegranate Coralline, a Garland polype, is found on others; and on old shells, and it is often cast up with them. The Sea-Oak Coralline, Garland polype, inhabits the leaves of sea-weeds and shells at low-water mark, like the Fern Coralline of the coast of Yorkshire, 
and to the north. One kind has a lid to its larger or generative cups, and is common on the

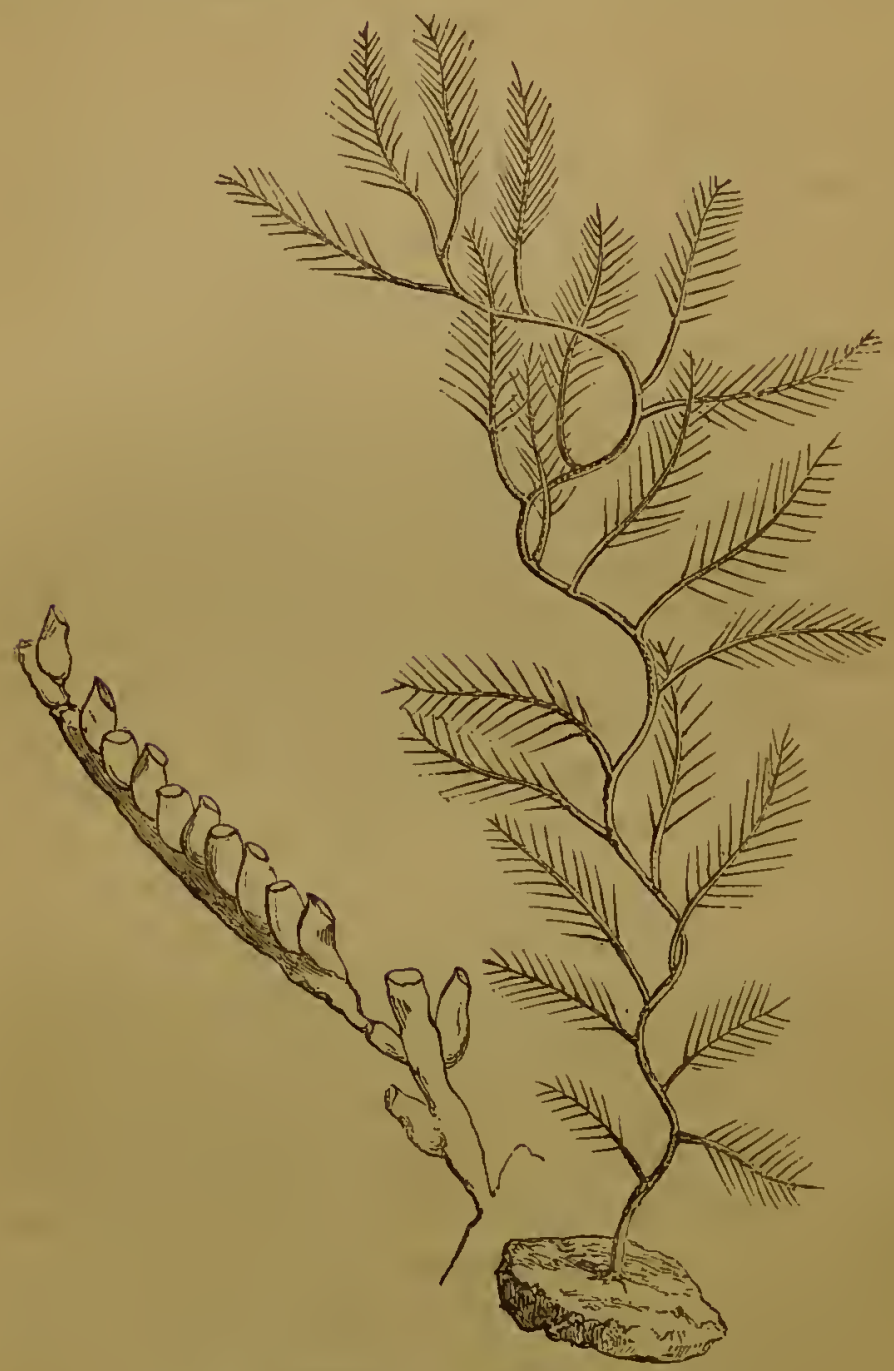

SICKLE-BEARD (Plumularia falcata).

stalks of the riband-shaped sea-weeds all round the coast.

There is a very interesting kind of these allies of 
the sea-jellies which, from its feathery shape, has been called Plimularia. Specimens are common, and there is a stem, and it has branches, and the cups are in one row on the branchlets. Moreover, there are openings in the horny envelope of the soft pith of the branches, which do not give exit to a polype-looking 'thing with its mouth surrounded with tentacles, but to a simple pith with many threads, or stinging cells in it. It is more or less like a long tongue, and is placed amongst the cups with polypes, and it is evidently an instrument for capturing minute creatures. The Sickle-beard is one of them.

But one of the most singular of these delicate creatures lives in very numerous colonies, on such an unexpected place as the outside of the shell, tenanted within by a wandering hermit-crab (page 206). It is called Hydractinia. The Hydractinia has a kind of crust for its formation, with tubes in it, and out from them comes a white film, which, under a magnifyingglass, presents a number of stems and polypes. Each one has at its free part a club-shaped end, which has several rows of tentacles around it. These, often twenty-five in number, are like the stem very irritable, flexible, and are covered with a sticky matter. The club is hollow within, for the stomach, and food gets in by the top, where the horny skin appears to be absent.

The tentacles are rather sharp, and when they are half-contracted they often appear to have a knob at the end, otherwise they are stuck out and are like so many thick threads. The stalk which supports the conical-shaped head has a thin and wrinkled skin with 
sharp, dot-like points on it, and probably they secrete a sticky substance. The polypes thus formed, cluster together like so much moss on the shell, and it would appear, if not in our species, certainly in one which frequents the American coasts, that some groups are male and others female. But there is no doubt, from the researches of Mr. Moseley, F.R.S., of the "Challenger," that some of the polypes act as catchers of food, and feed those which pay especial attention to increasing and multiplying. These last have minute little knobs growing on the stalk beneath the head, and which develop round bodies inside. After a while, motion is noticed in them, and there is every reason to believe that they burst forth and swim off as small jelly-fish. Some, however, give out little planulas, which settle down and grow like the parent.

It will have been noticed from this description that these polypes are different in shape from the Garland polypes, and that instead of being bell-shaped, with tentacles around the mouth, they are club-shaped, and have more than one row of tentacles halfway down. This last shape gives a characteristic to many little polypes which lead, like the others, two lives-one fixed on the sea-shore on plants and stones, and the other, freely swimming, as a pretty little jelly-fish.

In one which is found in the soutl of England the head of the polype is club-shaped, and has many tentacles on it, not arranged perfectly in circles. The stem buds, beneath the club, and little jelly-fish escape.

Before proceeding to describe some others of these polypes, a remarkable jelly-fish must be noticed. It is a small one, scarcely a quarter of an inch in length, 
and it comes out of the buds of some club-headed kind, or from some other polype already mentioned. Its peculiarity is this, that not only does the little floating thing produce eggs, which will in time turn to. planulas, and then to the creature resembling the parent of the jelly-fish, but it also produces otherjelly-fish like unto itself by budding. Buds form around the mouth, underneath and around the disc, break off, and sail away as minute jelly-fish. These are named after a late distinguished Scandinavian naturalist, Sars. There is one peculiarity about all these hosts of little jelly-fish, which distinguishes them from the great monsters, the jelly-fish proper. The little specks on the edge of the disc in the great jelly-fish are covered with a delicate pieceof tissue, but in the others they are not so, and therefore they are very visible, especially if coloured; and their possessors are called Naked-eyed Medusæ or Jelly-fish. Another kind lives fixed on sea-weeds in shallow water, and its stem consists of a single tube, which is creeping and threadlike. The cups for the polype are on long stalks, with markings like rings on them, and are bell-shaped with a toothed edge. The mouth is surrounded by tentacles, as in the Garland polype, and, in fact, there is not much outside distinction between them and this Campanularia, or Bell polype.

There is a stomach in the polype bud which leads to a canal that goes down the stalk, and even into the creeping stem or root. The buds, on stalks of their own, are very remarkable. They contain, soon afterthey are formed, numerous little jelly-fish attached to 
stalks. There may be twenty or thirty of these in each bud, and the day will come when they will burst forth, be cast loose from their stems, and swim off. They resemble hand-bells of a very flat kind, and the mouth is prolonged into a four-parted projection, which protrudes through a structure not seen in the great jelly-fish, but peculiar to these smaller ones, which fills up the disc underneath, from the mouth to the edge, with a layer of muscular fibres. They have four long tentacles, and when they have lived for some time they begin to play some very curious tricks. Thus a foreign naturalist, M. Van Beneden, was examining some creatures in his aquarium, and found hundreds of these very small jellyfish, and he caught some in order to examine them with his microscope. He began to draw some of them carefully in order to write a description of them. About an hour afterwards, on again looking at his specimen, he was amazed to find its shape changed, and the animal apparently turned inside out. The tentacles on the edge seemed to be reversed in their position ; the umbrella-like dome, from being convex was the reverse, and the curled lip-like proboscis seemed converted into the stem of a solitary polype. One of these Campanularians, called erroneously the Wrinkled-thread Coralline, grows on sea-weeds near low-water mark, and especially on the great Riband Tangle. It is a small thing, about an inch in height, and its stem is of a pink or rose-red colour; it is sparingly branched in a zig-zag manner, and its stem is ringed. The buds develop jelly-fish, but they never escape, and hang on by stalks for the rest of their lives. 
Sometimes after a gale, the deep gives up much weed, which only flourishes below low spring-tide mark, and on it some very beautiful stalked bell-shaped things are often to be found. In other instances the Fuci, at low-water mark, have them living upon them, and they may be placed in the aquarium and studied. They are small, not much over an inch and a half in length, and as they usually hang head downwards, they resemble a convolvulus flower, or wide umbrella with the stick taken out, and the ferrule made thick as a support. They are fixed by a kind of base or sucker at the end of their stalk, and the sides of their bell are angular and festooned. There are eight angles on the bell at its free edge, each of which has on it a bunch of tentacles ending in flat knobs. The mouth is in the middle of the bell, and it can be seen by turning the animal up, and it is four-sided. In the body, close to the mouth, four sets of cords divide into eight, and pass out to the bunches of tentacles, and all this gives a very radiate appearance to the soft, delicate, translucent creatures, some of which are pale clear pink in colour, or pellucid green, brown, purple, red, or yellow, with all the intermediate shades. The resemblance to a flower is remarkable, but the animal alters its shape readily, and contracts and expands rapidly. The mouth, situated at the top of a kind of proboscis, is tubular, and consists of a loose membrane, usually notched in four places, but capable of being expanded and made circular, by the will of the animal. It leads down to a cavity or stomach, which reaches into the stem of the creature down to its foot, and its four angles are carried down on the sides of the stomach like so many ridges. The body cavity is 
four-chambered, and the cord-like canals traverse it, as they pass from the bunches of tentacles to the stomach. 'The reproductive elements are produced in these radial cords, which have muscular fibres as well, that have to do with contracting and expanding the bell as it swims. The tentacles are in a crowd on each of the eight angles, and they are short, and have a disc on the top, by which they can attach themselves, or catch prey. They move very rapidly when the creature is excited. Usually seen fixed by their footdisc, these Lucernaria can unfix and swim with rapidity, by the alternate dilatations and contractions. of the body. One kind, the bell-shaped Lucemaria (L. campanulata), which is to be found from Berwick to Devonshire, here and there in possible situations, isasserted to chase its prey. It is to be found on seaweed near low-water mark, and is about an inch in height and of a uniform liver-brown colour. It is hardy and constantly expanded, for it will only contract on very troublesome handling. Lamoureux, a French naturalist, changed the sea-water of his specimen twice a day, and one of them used to play such antics, and moved so remarkably for a soft thing, that it was carefully watched. Its curious movements were produced during its attempts to catch an animalcule which dodged from right to left. When the little active victim got an inch off, the Lucernaria did not take any trouble about it, but if it approached near, the tentacles and the bell were moved here and there with great quickness and promptitude. The animalcule got caught at last by the tentacles of one of the rays, which instantly moved towards the mouth, but 
the others still remained expanded, and the catching set after awhile returned to their usual position. Usually the whole of the tentacles clasp in and move towards the mouth, when they have an important. prey. This kind has no tentacles on the edge of the disc intermediate between the others; but another one, called the Lucernaria auricula, has them. It is a widely-roaming kind, and is found adhering to seaweed around the greater part of the Irish and south of England coasts, but it gets rare on the north-east. It hangs down like the others as a rule, but in an aquar:um both kinds may sometimes be seen erect, and it moves slowly along the sea-weed in a very remarkable manner, and which causes it to resemble a polype, called the Fresh-water Hydra. It bends its bell down to the weed, and clasps or holds on with some of its tentacle suckers; then it lets go its footdisc, and twists it forwards until it touches in advance of the bell, when it holds on. It becomes fixed by the foot-stalk, and then the tentacles relax, and cast off, and this being done, over and over again, produces a slow and sure change of place. In other instances the creature moves by a slow creep of its disc-like foot. It is called, and its fellow also, the Lamp Hydrozoon. 


\section{CHAPTER V.}

The Sea Anemones-The Strawberry Anemone, its Construction, ILabits, and Physiology - The different kinds of Anemones - The Divisions of the Anemones-The Tuedia, Dianthus, Thick-tentacled, Daisy, Gem, and Troglodyte Anemones - The Parasitic kinds-The Mud-dwellersNotes on some Points of Microscopic Interest.

ONE of the commonest and most interesting animals which lives on the sea-shore between tide-marks, and which often manages to crawl up high and dry for a while, is known as the Red or Strawberry Anemone (Actinia mesembryanthemum). It is found stuck on to stones, sea-weed, pieces of wood and rocks, and appears under two very different aspects; that is to say, when it is closed and when open and expanded. Very few parts of the eastern and southern coasts are without it, and indeed it is discovered, with a little care, very generally. When closed up, the anemone resembles a little rounded lump of dark red and shiny flesh, and it feels soft and slimy to the touch, and there is a trace of an opening on the top. It. sticks hard to the stone, and often, if an attempt to remove it is made, it will tear and the inside comes out. Some are small, and others measure from $\frac{1}{2}$ an inch to 2 inches across. If the stone and the anemone be removed and placed in fresh sea-water, or what is 
better, if the creature is sought after in the pools of water left by the tide, it can be seen in its expanded condition, when it deserves, somewhat, the title of a sea-flower. The first thing that strikes the eye is a circle of numerous feelers, resembling the florets of a chrysanthemum or daisy, in position; and then in their midst is a flatsurface or disc, with an oval or round mark in the centre, which is the mouth. The feelers or tentacles are not long, but nearly equal in length the height of the body. The body is seen by looking at the side of the anemone, and it is observed to rise up like a stout cylinder, from a broad base. The outside of the body, of the tentacles or feelers, and of the disc looks smooth, and the colour is red or strawberry, liver-brown or olive, and there are streaks in a curious pattern on the body of blue or green, or yellow lines and spots. The tentacles are very numerous, and are in circles, one outside the other, but they do not follow in such an order as will place one feeler directly outside the one within, for they alternate. The feelers move slightly, now on one side, now becoming larger and stuck well out straight, and then they move a little to the other side. Where the outside set of feelers joins the side of the body, there is a fold of skin all round, and between this fold and the feelers are some beautiful azure-blue beadlooking bodies, as if the anemone wore a turquoise ring around its tentacular disc. The animal holds on fast by its base, but this may be examined, if an anemone is placed in a glass with sea-water, for it will sooner or later attach itself to the sides of the vessel, and then the curious flesh-coloured foundation of the 
thing may be examined. It looks fleshy, and there are markings on it, somewhat in the direction of the spokes of a wheel.

There are many varieties of this kind of anemone. One is of uniform liver-colour, another is of olivegreen, and the streaking lines on it are blue or greenish. The base, of most, is usually greenish, and it is encircled by a very distinct blue line; on the other hand, sometimes it is red and there is no line. The young and small specimens vary much in colour. There is one with a light olive-coloured body striped with white, the tentacles being ornamented with white and olive-green rings. The usual position of the anemone on the shore, is on shelving rocks, where there is sufficient sand to cover it up, and the feelers are just stuck out with the mouth in the midst. When the tide falls, the animal withdraws its feelers, and leaves a hole in the sand like that of a worm. If the anemones are watched, they will be noticed, especially in unsettled weather, to draw in their feelers, to become smaller, and then to expand them again. A good deal of waving slowly to-and-fro of them, is seen, and sometimes the creature moves slowly on the glass by means of its base. On looking at them in an aquarium in the morning, many may be found to have travelled some inches during the night, and perhaps one or two have given up holding on, and are floating head or tentacles downwards. They are just as stationary on other occasions.

Now if too many are placed in the aquarium at once, or if the water is not good, the mouth will open and a shining bladder-looking mass will come out of 
it. This is the membrane which lines the interior of the stomach. If the Anemone becomes very uncomfortable, it closes. That is to say, the feelers begin to get smaller, the body lower, and the fold of skin just noticed covers over the pretty blue bodies, and then overlaps the feelers as they become small. Just a central opening is seen for a while, and then that is reduced in size. When the Anemone crawls out of water, and they are rather fond of doing it, or when they are left high and dry by the tide, the shutting up goes on, sooner or later. They will remain closed for some time, and on some occasions, for days. A film of slimy stuff collects on them, and bits of sand and weed adhere to it. After a greater or less interval of time, the Anemone wakes up as it were, and especially under the influence of running water; the scum of skin is shed, the fold enlarges, the tentacles appear and enlarge, and the disc expands. If they are teased by having their feelers touched, they will close up, and if they have had a good meal they often do the same thing. They like the sunshine for a while, but on the whole they are most handsome and open in the shade, and it certainly is a sight to see them placed side by side over many square yards of seabottom, as the boat glides along with the smooth tide.

On touching the tentacles with the finger, they stick for a short time and then become loose, and if a shrimp, in paddling along, touches them with one of its long feelers, it withdraws instantly, and it appears as if there was some "catch-them-alive" stuff on the anemone.

A small crab may come blundering along and crawl 
right over the Anemones; they close their tentacles on him, and he may even disappear down a mouth, but quite as frequently he crawls forth intact. But many small thin-skinned things have a different fate. In swimming along, they touch a tentacle of the Anemone and are instantly arrested. They become motionless as if paralyzed, and immediately two or three other tentacles move and seize their rictim tightly. They all move then towards the mouth, and it comes to meet them by stretching out in their direction. After a while the morsel disappears down the mouth, the tentacles return to their places and the animal grows bigger, as it were, or looks rather full. A certain time elapses and the undigested parts of the food are returned in a lump, by the mouth, the rest having gone to add to the particular substances of which the Anemone is constructed. Small Crustaceans, such as shrimps, sand-hoppers, crabs, and small mollusca, constitute their food, and in fact they will swallow anything, and if that anything cannot crawl out of the stomach it is digested. Much water is taken in by the Anemone through its stomach, and much often comes out by the same passage, and also through the tops of the feelers, which are hollow tubes connected with a cavity beneath the stomach and on all sides of it.

They live long, and grow to some size, and they often meet with accidents, yet nature repairs their losses and restores tentacles, and even parts of their bodies to them. Very prolific are they. At certain times little ones with tentacles, and able to settle down and carry out their own destiny, are cast forth from the mouth by the score. But the great method of multiplication 
is by eggs or ova. These are produced within the body, and often make their way into the hollow of the tentacles; ten to fifteen at a time may be seen inside. Each is much smaller than a small pin's head, and is globular in figure, red in colour, and totally unlike the parent. They move round and round, twirling hour after hour, and when allowed to escape from the tentacle by snipping it, they move independently about like large animalcules in water. The minute creature soon grows longer than broad, and is seen to be covered with small rapidly-moving cilia. It appears to be made up of a number of cells, those on the outside having a movable process or cilium, but there is no trace of any inside. After a while it comes to rest, and a little hollow forms on the top and grows deeper and deeper. That is the mouth and future stomach. The two tentacles appear opposite one another, and then four (two more on either side), and then others are grown in the same manner, and the increase is in a definite progression of numbers.

The methods by which the Anemone digests, catches, breathes, and moves, will be noticed by-andby, but it is now necessary to remark on the other kinds which are found on the sea-shores, neglecting, however, those which, living always in deep water near shore, do not really belong to the littoral fauna.

There is no difficulty in collecting half a dozen kinds of Anemones on any rocky coast ; and after noticing their different colours, thick or thin, long or short tentacles, and the variations in the appearance of the body, there is a natural desire to classify them and to name them. A great many naturalists have done 
this, and unfortunately the most popular writers have not always paid attention to what has been done by the equally popular, or perhaps more scientific writers of times gone by. Hence every Anemone has a multitude of names; some have been called by the names of others, and some kinds have been said to belong to different species at different parts of their lives.

They are best divided into the following sets :Those with a broad adhering base or foot, with the surface of the body smooth, and without any holes in its sides. Those which are adherent, have the side of the body covered here and there with swellings or tubercles. Those which are adherent, but which have pores in their sides, which give outlet to thread-like tubes. Finally, Anemones which are not adherent by their bases.

The first division is divided in two: Anemones with tentacles, which can be retracted or diminished in size and lost to sight when the animal shuts up ;-those which have tentacles that remain in view and which cannot be retracted.

The Anemone already noticed is, of course, an example of the first set. It has been called by a host of names, and it should be termed Actinia mesembryanthemum. Actinia is taken from aktin, a ray, and the other long word means a kind of Fig-marigold; and the ice-plant may be taken as the example. The expanded disc of the Anemone is somewhat like the flower. Another Actinia, greenish in colour, not so tall as that just mentioned and rather leathery, is called the Pearl-bearer, but why, it is difficult to conceive. A kind is found on the Scottish coasts with white 
beads around the tentacles, and the body is red, without a blue rim to the base; and a variety of this with slender tentacles is found further south in England.

The beautiful blue beads (sometimes white) around the upper part of the body in Actinia mesembryanthemum will be noticed further on, because their construction is very remarkable, and opens up the question of the possibility of the creatures seeing and feeling, but their absence or presence denotes that the creatures belong to different kinds. Then there are some Anemones which would be introduced into the genus Actinia, with the kinds already noticed, but they have no coloured beads. They are grouped under the head of Paractis, a fanciful name derived from the Greek for "on the sea-side" (para-akté). One is probably a true Actinia, the blue beads having been overlooked, and it is found on the Irish coast. It has a gray body with upright white lines, white feelers, few in number, and the mouth is yellowish. Another kind found in Scotland has the gift, not peculiar to it however, of enlarging its base in one direction, and casting off a piece which turns to a new anemone of the same kind. As this process leaves the foot in a lacerated-looking condition, it has been called $P a$ ractis lacerata. It has black and white lines on it, and has been called the Widowed Anemone. Down on the Devonshire coast at Dartmouth, there is a semitransparent, colourless Anemone, with a blue line around the base of each tentacle, and it is termed Paractis pallida. A pretty little Anemone, with very short tentacles terminating in bead-like globes, is found on the Irish coast. The body is a brilliant 
green in colour, the mouth has brown stripes around it; the tentacles are not perforated at the end, and their tips are of a brilliant rose-tint, the rest being redbrown. On the Guernsey shore there is a very tall Anemone, constricted near the base, and it has two distinct circles of tentacles. The outer circle has them moderately long and numerous, and the inner comprises sixteen tentacles, which are about three times as long as the others. The body is brown in tint, and has long blue lines on it. It is called, from the two rows of tentacles, Dysactis biserialis.

There is a perfect marvel of beauty, in the form of a very small narrow-stemmed Anemone, with a broad circular disc. The vast number of tentacles, the larger of which have a minute globular head, the yellow and emerald-green of the stem, the transparent disc with green spoke-like markings, the green mouth, the umber coats, and the pink heads of the tentacles give a superb colouring. They are not common, except in one or two places, and there they hang on the rocks at extreme low water, as on the rocks at Torquay round to Ilfracombe, and also in the neighbourhood of Cork. They are called the Green Globehorns.

The kinds with tentacles which cannot be drawn in must now be considered:-First of all there is a set with long tentacles; and one described by the good old English zoologist Pennant, in 1777 , is now called Antheus cereus, from its waxy look, we must suppose. It is known at once by the long sea-green satin-looking, red-tipped, eighty, hundred, or more tentacles. The body is long and pillar-shaped and 
furrowed, it feels smooth, is shorter than the tentacles, and is usually of a light chestnut-colour. The smooth, snake-like tentacles, stout as they are and ever in movement, characterize this kind, which has a great range in the sea below tide-mark fixed to rocks. They rarely come up within tide-marks, and when in the aquarium are seen constantly moving their long feelers. The Cornish coast and that of Devonshire, as far west as Torquay, and along the Welsh coast, appear to be favourite haunts. Some of these snake-armed Anemones are pale in colour, and then the delicate violet of the tips of their long arms is very pretty. They are great fidgets, the arms are never quite still, and there is always some one or other of them which is unsettled and uncomfortable. As they are never drawn in, nor become perfectly invisible, like those of the common Sea-Anemone, and as they are somewhat distinet to the touch, the arms characterize the kind very readily. When kept in' clean water, these Anemones wander over the glass and bulge out their sides, especially close to the disc, before moving in that direction. Sometimes they come half out of the water and hang head downwards, and then every tentacle curls and curves, becomes straight again, and again curls up. But in their natural position, in the tide-pools and deeper still, these Anemones remain for a considerable time on the same spot, their long wavy arms entrapping and holding shrimps and other tiny things, which are carried to the mouth and digested.

Perhaps the most beautiful of all the Anemones 
which are found within low-tide mark on rocks and deeper, is the plumose kind, called Dianthus; it is a large kind, and is known at once, by the upper part of the body or disc being in lobes carrying a multitude of short slender tentacles, which have a very downy, furry, or feathery appearance. The body is long, with circular folds around it, and it is usually narrowed above, so that the cauliflower-looking top hangs over it, at the sides; some few tentacles occur within the plumed sets. The colour varies; sometimes it is all orange, or olive, or dark brown; and other specimens are white, with tentacles pale orange or dark brown in colour. It is smooth and very jelly-like, being transparent here and there.

Some of these Anemones are 6 inches in length when expanded, and 3 in thickness and the transparent state of the skin around the mouth enables some white bands to be seen internally, which pass straight from the mouth towards the sides of the body, separating off as many spaces. These spaces relate to the tentacles which open into them. It is said that this kind has holes in its sides, through which threads, which sting, pass, but there is some doubt on the point, and as it does not seem to retract its tentacles completely, it comes within the set now being noticed, and under the genus Metridium. It is found on stones and shells on the coasts of the east and south of England, and also on the Welsh coast, and may be got from the Frith of Forth, and at Gateshead.

The next set of Anemones, some of which are very: common on shore, are known by the rough skin of 
the body having warty-looking pimples on it. Each wart has a little pit in it, which produces very slimy stuff, and this causes sand, small stones, and dirt to stick to the body, One of these is found on and in sand nearly everywhere, where an anemone can live, on the British coast, and is known by its large size, flabby feel and look, and the several rows of short stout conical tentacles; and by the irregular manner in which the warts are moderately closely placed together. It varies much in colour; it may be red, red and white, or orange and yellow intermixed. The mass is often dull olive, streaked with crimson, and the warts are pale gray. A beautiful kind has the thick tentacles white with bands of pink; another has brownish-white and crimson bands, and all merit the common name of the Thickhorned Anemone.. It is called Cereus crassicornis, or the Thick-horned Cereus. Some naturalists give it the generic name of Bunodes, or Tealia.

The Gem Anemone is one of the same group, and its symmetrical colouring gives it great beauty and elegance. It is known by the rows of pearly-looking kinds of warts placed along the length of the body, and by the strongly-marked white bands on the thick-set tentacles. When the Anemone closes up, the warts are arranged on the outside skin like the rays of a star; and when expanded, the tentacles are very beautiful. Their upper side has a dark groundcolour, across which are pearly-white, bluish, and greenish bands. The animal itself, may be rosy-pink tinted with ash-gray or clear green. It is found in crevices of rocks or pools, and is common, but, like 
the other just noticed, is delicate and requires care in keeping. The wart-like bodies enable it to cover up the body, and it is very amusing to notice how this swells out when plenty of fresh sea-water is given. They are great gormandizers, and few things escape from the sudden clasp of all their tentacles, or from their very sticky points.

The Daisy Anemones are common on the south and west coasts of England, and as they have, when expanded and in full vigour, a long, slender, cylindrical body, with a broad, flat, circular disc, and small numerous yellow-brown but white-spotted tentacles, and the outside of the disc and that of the body are dotted here and there with small white warts, they are very soon recognised. The round tube of the body, like a stalk, lets the top wave to and fro, and the top of the disc is well provided with tentacles of different sizes, in six circular rows. These differ in length, and those near the edge are mere pimples. They are almost transparent, and some are of a pale ash-colour with brown spots; others marked with white spots are chestnut in tint. The disc is very star-like, from the radiation of stripes and colour from the mouth outwards, and there is a beautiful mixture of brown, yellow, ash-colour, and white on the rays. The creature changes its shape very frequently, and covers itself with sand and dirt when it is contracted, and looks like a piece of muddy sand. When in a rockpool of a few inches depth, the Daisy Anemones often look extremely graceful from their ornaments and colouring; and the bars of light colour on the arms, the dark general tint and the pearly warts, combine to 
produce a very pretty effect. They stretch themselves out and make themselves as tall as possible, and look something like tall mushrooms with a cupshaped top, and they jerk down one side of the body in a remarkable way, should anything touch it. The Rosy Anemone with brilliant purple tentacles; and the Scarlet-fringed Anemones of the South and West of England and Bantry are allied to the Daisy.

The next group of Sea-Anemones found on the shore between tide-marks, or lower down near low spring-tide, have in some instances not a very definite zone of habitation, for species are known that inhabit the outside of shells, which are used as houses by the Soldier, or Hermit crab, and these wander much about. The species of the group have been called by different generic names, but they all have this peculiarity, that the sides of the body are minutely porous, and through the holes, threads may come out which are of a stinging nature. English authors, such as Forbes and Johnston, named them after an English observer, Mr. Adams, and the French authorities retain the name Adamsia. The Adamsias have the pores situated close to the base by which they adhere, and the disc or upper surface has not bright-coloured tentacles. The British kinds fix themselves on the dead shells of whelks and other spiral shells, which are tenanted usually by a Hermit or Soldier crab.

The kind now under consideration is large when full grown, and sometimes 3 or 4 inches in height. It is cylindrical in shape, and the body is marked with irregular bands up its length, of a red-brown tint. These stripes are sometimes purple in colour, and the 
rest is of a sandy tint. The covering is rough and warty, the tentacles are short, and are marked with long broken brown bands. The disc is often very large. When no whelk-shells are to be had, it will fix itself on a stone, but it is evident that it likes the shell, not only because it gives its base a firm support, but also because it has a chance of being tenanted by a creature which will move it about. Doubtless the change of position is rather to the benefit of the Anemone, as a good chance is given of obtaining more food than if it were fixed. But it must not be imagined that the lodging on the shell gives the Adamsia any of the food caught and demolished by the crab. It is not a parasite or diner with the crab, but the crab is its unintentional locomotive. The name parasite is therefore not correct.

The next kind of Anemone belonging to this particular group of thread-casters, is very different in form to the last. It is a beautiful creature, and has been found nearly all round the coasts, either between tides, or brought up by gales from deeper waier, or in nets. It is short, flattened, and covers much of the shell as with a cloak. Hence its name, Adamsia oalliata. With long furrows on its brown or reddish body it has the foot festooned as it were, and the margin of the disc is a pale scarlet. The edge of the mouth has a stripe of pink, and when the body is expanded, the upper part seems to be nade up of fleshy bars forming a net, and lined with a delicate membrane. There are perforated warts on the outside, and from them come the white stinging threads. The white disc is long, narrow, and oval; and the tentacles on the 
margin are numerous, short, and in three or four irregu lar rows. They are shorter than the body, sharp, and white, with a streak of brown. The mouth is large, the lips are white. The slit in the mouth of the whelk-shell is covered by an expansion of the base of the Anemone, which secretes a horny bridge for its support. This arrangement is particularly fortunate for the Hermit crab which frequents the shell, enabling it to live more comfortably and safely than if the home it often steals from others were open on one side. It is supposed that there is some parasitism in this instance, and that when the Anemone catches a big prey the Crab helps himself, and that when the Crab loses a victim it tumbles into the power and as fatal grasp of the Cloak Anemone. There are several of these Adamsias scattered about the globe, and most of them live on shells tenanted by the Soldier-crab of the particular part of the world. They are found on the Scottish, Irish, and Guernsey coasts, and in the south-west and west of England.

A rather common Anemone lives in holes in the rocks, down which it withdraws on the approach of danger ; and it sometimes buries itself in sand, up to its tentacles, and draws in when disturbed. It is olive or gray, with whitish long stripes, and the tentacles are large, pellucid, gray, and bordered with white, with a mark like the letter $B$ at their base. As it gives forth threads when irritated, it probably belongs to the group of anemones now being considered, and from its peculiar habits, it is called the Cave-dweller or Troglodyte. Finally, a very common little Anemone, from the south-west coast, has long slender 
white tentacles in considerable numbers, and a small light brown-red body. It is called the Snowy White, and it would appear to belong to those which cast out threads. Mr. Gosse mentions the Orange-dotted Anemone with white tentacles, from Tenby, and the south-ivest of England; and the Sandalled Anemone with but a few tentacles, pure white in colour, except at the base, which is purple, from Guernsey, Dartmouth, and Ilfracombe.

The Rev. Charles Kingsley discovered a very remarkable Anemone, which belongs to a group without an adherent base, but it has some peculiarities of construction which are not seen in any others. It was found in the neighbourhood of Torquay, living buried with its body upright in the sand, the disc and tentacles being visible on the surface. It was not fixed to any substunce. It has a pear-shaped body, which is transparent, and has white lines running from one end to the other, at regular distances. The disc is oval, and there are twelve tentacles, which are ornamented with arrow-headed crown-markings on a white ground, and they are bent outwards and backwards. There is a fleshy proboscis sticking out from the mouth, the top of which spreads into a clubbed head divided into pimple-looking pieces. It is protected by a very thin skin, which is apt to burst and hang in shreds when the animal distends itself. It is found in wet clean sand at low-water mark; and when the sand is in the least disturbed, it draws in like a worm and has to be dug out from a depth of about nine inches. On being taken out of the water and put into a glass with sea-water, they swell out, and 
their movements are rapid and spasmodic. It has been named the Speared Peachia. The first name refers to the ornaments on it, and the last to an excellent naturalist, Mr. Peach. Mr. Gosse describes a baseless Peachia-like creature from Cornwall, where it is found at extreme low water. It has twelve tentacles in one row, on a body which is worm-like and extends ten or more times its diameter. Another of the same genus, Holocampa, is found in South Devon between tide-marks.

There are some rare Anemone-looking animals, reaching to 7 inches in length, and only having a thickness of $\frac{1}{4}$ of an inch, the disc and tentacular end being about an inch and a half in diameter. They have been found in the shore mud and gravel in the Menai Straits and at Heron Island, near Guern sey. They have a distinct outlet at the base, which is bulbous, and they live in a loose membranous rugged tube, closed below, and stuck in the mud. This tube is cast off, as a secretion from the slimy body, and it protects the animal, which is called the Vestlet, or Cerianthus Lloydii, by Mr. Gosse. The disc and tentacles remain expanded, and this fine species is a hardy dweller in the aquarium, feeding on minute Crustacea and beef.

It is now necessary to notice the general construction of these Anemones and to explain their minute structure, and the part they play in nature. On touching a Sea Anemone when it is expanded and attached to a stone in the water, it contracts, the tentacles diminish in size, the mouth seems to get lower in the body, and the sides overlap, so that only a 
little lump of stuff remains adherent. This will often get smaller, so as to resemble a mere film of fleshy matter. A sensation as of touching something slippery and slimy is given to the hand, for a quantity of sticky colourless secretion covers the Anemone, and increases as the creature is irritated and handled. On touching the tentacles of some kinds they stick, for a moment, to the finger, and then diminish in size, after giving out water from their tops. It is also very soon discovered that the Anemone has something like a will of its own, for it will not submit to be removed from its stone. The foot or base adheres as if it were gummed, and will often tear, rather than give way. It can be removed by great care and peeling; but even then some threads may escape from the inside, and the result is too often fatal. But the Anemone can shift its own ground when it likes, and it often leads a free life, wafted here and there on the sea; on the other hand, some kinds will occupy the same stone for years. All these things are readily observed. It will be noticed also that most of but not all the Anemones enjoy a bit of sunshine, and that they get out of the dark into the light; others, however, do the reverse. This shows that they have some gift which approaches special sensibility. They will greedily swallow some things and will hardly condescend to draw in their tentacles to touch others, so that there must be something like taste. When they have swallowed and have digested and returned that which is of no use to them by the mouth, they often seem to take in a quantity of sea-water and to blow themselves out with it. It gets into the hollow tube within the tentacles, and 
they swell out; and when the common Thick-horned Anemone is found in this state, it will, if touched, give out quantities of water from the ends of its many feelers. If the water given to the Anemones be boiled first of all, and then allowed to get cold, they soon close up and often die. They require air in the water to breathe, and the oxygen in the air is of as much importance to them as to any animal. Moreover, if too many Anemones are put in a glass to be kept, they will die, or the weakest will succumb until there is a proper relation between the numbers and the amount of water. In fact, the Sea Anemone decomposes the air suspended in the water within its body and adds some carbon to the oxygen, forming carbonic acid gas. 'The creatures breathe, then, and the breathing is most fully carried out during digestion. Simple observation will prove that some kinds, especially the common Strawberry Anemone, retire from the water and close up by bringing the fold around the tentacles above the mouth. They will remain in that state for days, and their respiration must be at a very low ebb ; their digestion is not going on, no food is taken in, and a great deal of slime collects on the body, forming a sort of crust. But all that time changes are going on inside, and it appears that repairs are being done to the skin especially. Some close up in the water and look like films, and the prawns and shrimps pick at them in a most persevering manner, but without much result. The Anemones, therefore, have skins, sensibilities, stomachs, tastes, muscles to move with, and must breathe and digest. So they have structures, by which these things are performed, and by which they repro- 
duce their kind. Moreover, as has already been noticed, they sting and paralyze their prey. Clearly they have nothing hard inside, and they are made up of an outside skin, an inside one, and some soft substance between the two in which are muscles. The outside skin is that of the sides of the body, of the bottom of the base or foot, and of the outside of the tentacles and of the space between them and the mouth. The microscope and a little inspection are necessary in order to make out the structures, and the outside skin consists of the following remarkable "cells." There are large bladder-looking cells observable under a high magnifying power, which when pressed burst and give out a glairy liquid. They are the slimeproviders, and the membrane of the cell, or its wall, is thin and transparent.

These slime-cells are found also on the tentacles, where they are usually smaller than on the body, and they do not appear to be present on the foot or base.

Side by side with these, as on a pavement, are two other kinds of cells, forming altogether a delicate skin. First, there are small ones crammed with grains very minute in size indeed, which are the colouring substances of the Anemone. They are placed in batches, and here and there in abundance, being sparing in other places, and the grains are coloured. Secondly, there are the sting-cells, which exist by the million. On looking at a piece of the skin under the microscope numerous minute sharp points appear to stick out from it in and amongst the other cells just noticed; and if they are touched or, as is usual during 
the preparation of the skin for the microscope, if some of them are injured, the point is seen to be the tip of a long and excessively minute thread, which often has a barb upon it like an arrow. Often the thread may be seen to come out suddenly or rapidly from somewhere and to extend widely, and sooner or later the glass will be covered with these delicate hair-like threads. Care will show that there are some cells which still retain their threads, and they are sausageshaped, very transparent and small, and contain a little fluid. They have the thread arranged within them like a spiral string wound round the inside, the end coming up the middle to join the point seen outside. Touch them, and the point gives forth the thread until no more is left in the cell, and then it is seen that the end of the thread is continuous with the wall of the cell, as if they had been drawn out. These cells have been called by many names in English, such as thread-cells, lasso-cells, stingingcells, and by many very hard names in scientific Greek. They certainly do irritate a tender human skin, and paralyze minute living things very remarkably.

The size of these cells differs, and their closeness also ; moreover, as they are constantly destroyed, their places have to be reoccupied, and this can only be done by smaller cells of the same kind making their way from beneath to the surface. So there are always young cells coming on. Rows then of these different kinds of cells form the outside skin mainly. In many, but not in all, there are also cilia cclls on the outside skin of the body, but in all Anemones they 
are found on the top, between the tentacles and the mouth, where they are of the greatest possible importance.

The swelling around the mouth, which may be called the lip, has many slime-cells and many cilia. To complete the story of the outside it remains to say something about the under part, which is sometimes called the base or foot. Its edges, so frequently ornamented with a blue line in common kinds, resemble the rest of the sides of the body; but further in, the colouring cells are deficient, as are also the cilia-cells and thread-cells. A modification of the slime-cell appears to predominate, but the contents are not so slimy, nor do they readily escape. But there is not much known about this part.

The under or inner skin must now be considered, and as it covers the whole of the inside of the body and the inside of the tentacles, their anatomy must be explained. The mouth opens downwards into the stomach, which is a shallow kind of sac, which is open below, where there is another sac called the visceral cavity, with many side-sacs opening into it. The stomach is very extensible, and is lined with a tissue, which has some folds in it which unfold and become flat as the food is crammed in, and this tissue is continued down on the sides of the large visceral cavity and into its side-sacs. The side-sacs are formed by layers of the body, which pass from the wall of it inwards; they are separate, and their tops can be seen on the disc like so many spokes of a wheel. Their inner edges come into the visceral cavity like so many curtain edges, and they are of 
course closed in above by the disc between the radial markings. A tentacle is placed on the roof of each, and as there is a hollow in the tentacle, it opens into the sac through the roof. Water coming in at the lips, gets into the stomach, passes down to the visceral cavity, and wanders here and there in the sacs around, and makes its way into the inside of the tentacles, and comes out in some kinds at their top, where there is an opening.

As the sacs come up to the disc, they must surround the stomach, and probably this has some openings into them. The stomach's duties are to digest food; and that of the great cavity and the sacs, is to carry the digested food over their surfaces, so that it can be taken into and nourish the body. The microscope shows that two kinds of cells are found in enormous numbers on this curiously in-and-out inside tissue, and that really this inside lining is a continuation inwards of the outside skin. The cilia-cells abound; and here the cell is very minute, and has several minute cilia or hairs on it, which are always in vigorous movement. They cause currents in the water in the inside, and as they abound within the tentacles, much movement occurs there. They are the causes of the circulation of the water and digested matters over the surface, for the creature has no blood-vessels or canals for blood to travel in. Besides the cilia-cells there are a few thread-cells, and they occur in vast quantities on the curtain edges. They appear to be useful in making up a coating, but they can be of no use in catching or killing, for that has all been done. Large bladder-cells and small 
ones containing colourless, slightly gummy-like fluid abound, and they probably contain a slight acid, by which the flesh and substance of the prey are digested. The insides of the tentacles are crammed with cilia. The eggs collect in the curtains of the sacs and in their fringed edges and escape, and some get up into the tentacles, but finally all pass out by the mouth, for they are covered with cilia and move along, but they are not like their parent in shape.

Between the skin of the inside and the skin on the outside of the animal, are the muscular structures which enable it to move with greater or less vigour, and which cause the tentacles to clasp and catch prey.

Anemones, so usually quiet, and passing such lives of sameness, do appear, in some instances, to have a will of their own. The common one gets out of water and settles in a sheltered place for some hours, for a day or two, and it will do it. Most seek either light or darkriess, and very pertinaciously. They taste, know what is good, and appreciate light. But no connected nervous system has been discovered, but only portions of one here and there.

It was noticed in the description of the common Anemone that it had a circle of pretty azure-blue beadlike ornaments outside its tentacles, and just within particular fold of skin. All Anemones have not these things, but nevertheless their construction is very remarkable, and may be of some importance to the animal in the way of distinguishing light from darkness. The blue colour is given by myriads of very minute grains less than a 20,000 th of an inch in length and breadth; they are opaque, and are 
contained in minute cells, and their beautiful colour is from light reflected from them. Their situation is curious, and they appear to act in stopping the light, in its passage from the outside of the beadshaped bodies to their innermost part, from wandering out by the sides of certain long, transparent things something like lenses in shape. On the outside of the blue bodies is a thin film of very delicate microscopic rods placed side by side, with the points outwards and inwards. The points are rounded, and the rods are transparent cells filled with liquid. Beneath them are some bladder-shaped cells containing clear fluid, and beneath these some large rods many times larger than the others, and placed in the same way. Light, on coming against the tops of the outside rods, would enter and reach down them, but would extend on all sides as well. But between the rods are the minute granules, so that each rod is a little telescope lens, and this is true for the bladder-cells and the large rods. Evidently light can come down some little distance into the tissues of the animal in this way. Now, at the inner end of this arrangement of rods. and cells, there is the usual tissue of the body, but in and amongst it, there are star-shaped, many-cornered cells here and there, with long films attached to them, and they certainly resemble nerve. This is all there has been, up to the present time, found in the shape of nerves in these animals.

There is an interesting fact about some of the Anemones which is somewhat important, as it introduces the next group of shore animals to our notice. In some there are minute pieces of gritty-feeling 
substance in the skin, near where the blue bodies are in some Anemones, and a lens being used, after a little inspection it is proved that small irregular grains of carbonate of lime or mineral dead substance are scattered here and there, and amongst the structures between the outer and inner skin. This is the result of the deposition of the mineral from the digested food, as it circulates from cell to cell, and it foreshadows the solid skeleton of the corals. 


\section{CHAPTER VI.}

The Stony Corals and their internal construction-Caryophyllia-Balanophyllia-Sphenotrochus; Alcyonarians and Tunicata of the Shore.

In many a quiet nook of the Devonshire coast where the shore is rocky, and free from mud and the accumulation of sand, some very unexpected things are to be found, when the tide is very low, or in the natural pools which are never dried up about the limestone fore-shore.

Stuck on to the rock, and usually hung on, so that they look downwards, are numerous pretty little things, the largest being half an inch high, and having about the same breadth, which look like rather -arved sea anemones. They look soft, and the white, green, orange, red, and yellow colours of their substance are seen on numerous tentacles, and on the structures which surround a very elegant and rather long mouth. The shape is that of a short and broad Sea Anemone; the tentacles are placed on the disc in which is the mouth, and they move slowly now and then, and are just as sensitive as those of that creature. But on looking attentively at these animals, some whitish-looking pieces, like so many thin edges of plates, are seen placed letween the sets of tentacles coming in from the rim of the disc 
to the mouth like the spokes of a wheel. The sides of the creature look white or pale-green close to the rock, and they are not covered then with a film of soft tender stuff, as in the Anemone. 'The finger soon tells us that the sides are hard and unyielding; and, singular to tell, no sooner has the creature been touched, than the tentacles, instead of being withdrawn within the contracting skin around the disc, seem to grow smaller and disappear between the spokes just mentioned. The colours all go, and a white mass is seen with a nearly transparent film over it. The mass is hard, and is evidently the horn or skeleton of the animal. It appears to be very complicated in its construction, and the plates just mentioned may be seen forming a curious radiating structure with the mouth, at the bottom of which is a hard substance called the column. After a while, if no more touching is inclulged in, and the sun is allowed to shine over the pool without any shadows coming in the way, the white mass seems to swell on the top, colour begins to be seen, and then some tentacles appear and stick out beyond the disc on the upper surface. Others appear coming up from the orifices between the spokes, and growing over them, and at last the creature looks soft and alive.

If one of these animals is broken off the rock with a chisel, it may be kept in an aquarium. But if, when removed from its piece of rock, the creature is moved in the water with violence, all the soft part is carried away, and the white skeleton remains. It is a little coral, a stony coral or madrepore, so called to distinguish it from the red coral of commerce, 
which belongs to a different animal that lives in deep water, far from our coasts. It is made up of the same substance as those corals which form coral islands and reefs, namely, hard carbonate of lime; but, as a whole, it is not a thing which could form part of a coral-built coast, for its minute details differ from those of the great assemblage of minute animals which build up reefs and rocks. Our little coral is all one animal, and has obtained its carbonate of lime from the prey upon which it lives.

The tentacles of the coral now under consideration, and which is called Caryophyllia Smithii, are numerous, and are in several sets, each forming a circle parallel with the edge. Resembling, somewhat, those of an Anemone, they are paler in colour than the rest of the soft parts, and their shape and length depend very much upon the health and position of the coral. If the coral is hung on to a rock, so that its tentacles can droop, and the water is full of air-bubbles and food, they project often as much as the length of the body of the coral, and are transparent, with little white knobs at the end. When in this favourite position, the soft parts of the coral are always well nourished, and they reach beyond the internal skeleton considerably, so that it cannot be distinguished at all. The mouth has long lips, often red in tinge, with bars of white, and the disc around it is marked with pretty colours, red or orange usually, but sometimes green, arranged in twelve star rays. On looking at the top of some of these Caryophyllice, the column at the bottom of the cup looks like the axle-end of a wheel; the large plates resemble the spokes, and the 
basin or wall-edge the tire; and outside there are little projections, which are, as it were, continuations of the plates, and which have the same position as cogs on a wheel.

The large plates are called "septa," as they divide the basin inside into many different parts, for they reach down to the bottom of its cavity. They are delicate in structure, arched above, and transparent when moist. When dried, and the film of living matter is washed off them, they can be examined with a magnifyingglass, and it will be noticed that little threads of the film are stuck on to them, as if there was filmy stuff inside amongst the hard carbonate of lime. Really, each septum can be shown to be made up of two, placed side by side, with a film between them. When the septum is put in weak acid and water, it gives out carbonic acid gas in bubbles, becomes smaller, and finally only a shred is left. The gas has gone off, the lime has united with the acid, and the filmy stuff of the plate remains. It is a mass of shreds arranged like thick lace, and it has the shape of the plate. It is the soft part of the hard skeleton of the septum; the part which nourished the plate, gave it the carbonate of lime, and enabled it to grow. Now, taking another plate, rub it on a hone until it becomes so thin that a microscope may be used to look through it. The thin plate when highly magnified is a splendid object, for the carbonate of lime is not placed anyhow in it, like so many grains of chalk; on the contrary, it is in the form of long, broad, transparent needles, placed side by side and on top of each other, and they radiate 
from the position occupied by the shreds of the film in the plate. Other parts of the coral show the same structure, and it is not difficult to put a whole one in acid and to get the model in soft filmy stuff, or to have it cut and sliced thin, so as to use large pieces for microscopic purposes. Everywhere there is the connection between the formerly living soft tissue and the carbonate of lime, and the first has deposited the last out of the nutrient fluids.

The hard parts are thus lined within and without by the soft tissues. The mouth of the coral leads to a short stomach, and this, as in the Anemone, to a large visceral cavity. This extends between the septa or plates, and is limited by the covering of the disc. Again, the tentacles are stuck on to the disc, are hollow and they open below into the visceral cavity. One set of tentacles is close to the plates, and another is nearer the mouth. The food is wafted to the mouth, carried to it by the myriads of cilia or moving hairs of the disc, or is captured by the tentacles and taken by them to the opening and dropped in. It passes into the stomach, and some of it is dissolved, and more is digested in the visceral space. Currents of water, mingled with the digested food, are wafted about inside, and the soft tissues absorb the pure protoplasm and the carbonate of lime. The first goes to replace the wearand-tear of the body, and to add to the growing creature, and the last is deposited in a half-crystalline form in the midst of soft filmy stuff in the form of the mineral called arragonite. The selection by the tissues of the carbonate of lime is very remarkable; 
it is selected and deposited, not by chance, but according to a rule which has a very remarkable arithmetic. In the very young coral there are two septa and the commencing column, and very shortly two other septa appear on either side, making six in all, and they are large, and about the same distance apart. Then six other septa appear, one in each interval between the larger or primary ones, and thus twelve are found. After a while twelve more appear, one in each interval of the preceding twelve, and thus twenty-four are in existence, and to these twenty-four others are added. Usually there is some deficiency in this last set, as the corals are not always quite symmetrical. Nevertheless, the septa, as a rule, are in multiples of six, and appear with definite exactness. As they grow, the number of tentacles increases, and they have a numerical relation to the septa. Another interesting point is, that there are little internal plates, or pali, which appear before certain septa, and they grow up from the bottom of the cup by the side of the column. It will be noticed, on examining a dead coral, that each large septum is followed by three smaller ones, the middle of the three being the largest, and it is before this one that the little inner plate is placed. The pali are ornamented on their sides with tiny cupshaped bosses, and their free edge is arched, whilst the septa have large granules upon them, as is the case with the ribs outside, which have been compared to cogs. Finally the column is made up of a meshwork of ribbons of carbonate of lime, and very often the tip is as pretty as the centre of a daisy. 
A small coral, with a very brilliant orange or scarlet soft part, the tentacles being yellowish and wartylooking, is found at Ilfracombe. It is remarkable for the peculiarity of its skeleton, or corallite, which, instead of having plates and a wall made up of solid carbonate of lime, has them penetrated by large pores. Moreover, the septa unite together in a curious manner. It is called, from a fancied resemblance to a Barnacle (Balanus), Balanophyllia, and the other name given to it by its discoverer, Gosse, is Regia. The rocks at Torquay are said to be the dwelling-place of another small coral, which has been noticed by the distinguished French naturalists, MM. Milne Edwards and the late Jules Haime. They do not say anything about the appearance of the living animal, but describe the corallite as having a broad base where it is stuck to the rock, and as not possessing a central column. The plates are large, thin, and very crowded, and some are attached to others, but there is no column. It has been called Desmophyllum Stokesi. Possibly a small coral, which is found living in a few fathoms of water off the Cornish coast, off the Isle of Arran, and off some parts of Ireland, is sometimes cast up as a waif between tide-marks. The tentacles appear to be few, short, and enlarged at the top. The hard parts are remarkable for their shape, which is that of a very compressed sugar-loaf. The ribs are large on the outside, the plates are wavy, and the column is in the shape of a long plate. The coral is not fixed, but lived on the floor of the sea, stuck upright in the sand or mud. From its wedge-like shape (sphen), and 
from a fancied similarity to a top (trochus), the coral has been called Sphenotrochus.

All these corals are rare, and are what are called simple forms.

Amongst the waifs and strays occasionally brought by the tide and waves out of deep water, and cast into a rock-pool, or placed within that part of the shore which, although uncovered by low spring tides, is beneath ordinary tides, are polypes called Alcyonides. Small specimens continue to live in those spots, and there are some little kinds which appear to be really shore fornis. They are allied to the Sea Anemone group, but differ in having numerous polypes on one body, and each of these has eight tentacles, which are bipinnate; moreover, inside there is the same number of curtains which are not liardened by carbonate of lime.

The large kinds look and feel tough and leathery outside, and are known by the name of "dead men's fingers or thumbs," and some which are not divided, but which are single, are termed "cows' paps." Often the animal, found under a stone or weed, is not the eighth of an inch in thickness, and whilst it is usually brown and ugly, some are red in tint. On placing one of these Alcyonia in a tumbler of sea-water and watching it, a number of star-like markings, with eight rays, are seen on the surface and a polype soon projects from them. It has eight rays, with a row of minute knobs on the sides of each, a mouth, and internal organs, and it is as it were enfolded in the skin of the whole. In the skin and between the polypes there are many meshes of a kind of fibre filled with a 
gelatinous substance, and on and amongst it are crossed and toothed semi-crystalline particles, called spicula.

Another group of animals, usually found in deeper water, has kinds which are cast up, and which may live under stones usually covered by the tide. They are leathery, or soft, or almost cartilaginous to the touch, and there are spiculce in the skin, but no internal hard parts. Moreover, the skin contains a substance, formerly considered peculiar to the vegetable world, called cellulose. Each animal has two openings, one for the water to go in and be breathed and for the food, and the other is the vent. Inside there is a muscular sac, also with the two openings, and it contains the organs of digestion, respiration, and reproduction. There is an elaborate system of water-communication. One of the commonest, the Mammillate Ascidian, is a little finger shaped thing, with a sharpish point where the branchial orifice is always open, and swollen sides, on which is the usually-closed vent and a narrow base of attachment. Some are ugly and others are splendidly coloured, and often they are found clustering among the tangles, like branches of "some strange, semi-transparent fruit." Some kinds are used as food, and the best are the ugliest. Others, which are in companies, and have therefore a compound body, are thus noticed by Edward Forbes :- "If when walking on the sea-shore, about low-water mark, we turn over large stones or look under projecting eaves of rock, we are almost sure to see translucent, jelly-like masses of various hues of orange, purple, yellow, blue, gray, and green, sometimes nearly uniform in 
tint, sometimes beautifully ornamented and variegated, and very frequently pencilled as if with stars of gorgeous device, now encrusting the surface of the rock, now depending from it in icicle-like projections. In examining these bodies, we find that it is not a single animal which lies before us, but a commonwealth of beings, bound together by vital ties. Each star is a family, each group of stars a community. Individuals are linked together in systems, systems are combined into masses. Indeed, few bodies among the forms of animal life exhibit such exquisite and kaleidoscopic figures as those which we see displayed in the combinations of the compound Ascidians." The Ascidians are thus divided into simple and compound. The mammillate kind is called SeaSquirt, from the manner in which the sea-water will squirt out from the orifice. It is one of the genus Ascidium, and its characters are, that they vary from I inch to 5 or 6 inches in length; the test (outside skin) is pale and semi-transparent, and the inner tunic is orange or crimson, and sometimes marbled with crimson and white. The ocelli are red or yellow, with a central red spot. The branchial orifice is eight-lobed; and the whole surface may be covered with papilla on which are bristles. They range from low water to 20 fathoms.

At Tenby there is a globe-shaped kind, called molgula, from molgos, a bag of skin; its skin is usually invested with other dead and living things, and the openings are on little and very contractile naked tubes. Another kind is found on sand, oysters, stones, and sea-weed, from low water to 30 fathoms 
deep. It is often orange-coloured or crimson, and collects together in bunches, each individual, however, being separate. It is called Cynthio.

One kind inhabits the mud, and looks like a worm, and it fixes itself in the shore of Rothesay Bay.

Amongst those Ascidians which are social, but not compound, are long, erect, stellated ones, with a mouth and transparent skin, the orifices being simple, and the body having coloured lines on it. These are the Clavelle, and they live on rocks and stones at low water. The compound Ascidians have their skins fixed one on to the other, but the individuals are separate. Botryllus, from botrys, a cluster of grapes, is a kind found on stones and weeds at low water, and it incrusts things. There are numerous systems, and they are prominent, round, or star-shaped, with central cavities, there being from six to twenty individuals in each system. 
CHAPTER VII.

The Sea Mats or Bryozoa-Flustra, Bowerbankia and other Moss Animals-The Sea-Shore Worms and their Divisions: The Ribbon Worms, the Nemerteans, the Sea Mice, the Sigalion, the Sanguine Eunice, the Sao; their construction.

MAny sea-weeds and stones on the shore, between tide-marks, are partly covered with growths which are small, horny, or of carbonate of lime, in the shape of minute tubes or crusty expansions of hundreds of cells or cups placed side by side. On placing them in clear sea-water, a furry, mossy-looking transparent film will cover them, and the eye, especially if assisted by a magnifying-glass, detects thousands of separate polypes in it, furnished with many tentacles, each of which has large cilia or moving hairs on its sides. A perfect whirlpool of movement goes on around them in the water. They have been called Moss Animals, or Bryozoa, and, from their numbers, Polyzoa. Most of the kinds found around our islands live in deep water, or in the zones below the true shore-line, but there are many examples on the shore everywhere. The commonest are found on the leaves of the broader sea-weeds and on their stalks; and they are brownish things, which are harder than the plant, and are made up of a vast number of longish shallow cups, placed side by side; joined and covered in, ex- 
cept at one spot. Sometimes the ridges which connect one cell, as it is called, with another, have short or long spines on them. They look like some network, and as if Nature had been weaving, and as "Flustrian" is a Saxon term, it is said, meaning to weave, and they have been called, Flustra. Every sea-weed in some localities has some patches on it, and this common object of the sea-shore is passed by, constantly, as of no interest. But it is wonderfully made. Of course when half-dry or when taken out of a small pool, only the hard part is seen, the polype with its tentacles being withdrawn under the cover of its cell. But the hard part is beautiful, not only from its adaptation to the life of the creature, but from the extraordinary repetition of the same patterns of structure in the thousands of cells which constitute each sea-mat or flustra, and also for the regular order in which they are placed side by side, and before and behind, one on another. An old author, Hooke, who wrote a book entitled the "Micrographia," is often quoted in illustration of the beauty of the one kind of humble flustra. He wrote: "I have not, among all plants and vegetables ${ }^{1} \mathrm{I}$ have yet observed, seen any one comparable to this seaweed. It is a plant which grows upon the rocks under water and increases and spreads itself into a great tuft, which is not only handsomely branched into several leaves, but the whole surface is covered over with a most curious knot of carved work, which consists of a texture much resembling a honeycomb,

1 It was at first taken for a plant. 
for the whole surface on both sides is covered over with a multitude of very small holes, being no larger than so many holes made with a small pin, and ranged in the neatest and most delicate order imaginable, they being placed in the manner of a quincunx, or very much like the rows of the eyes of a fly, the rows or orders being very regular which way soever they are observed. These little holes, which to the eye look round, when magnified, appear very regularly-shaped holes, representing almost the shape of a round-toed shoe, the hinder part of each being as it were turned in, or covered by the toe of that next below it. These holes seemed walled about with very thin and transparent substance, looking of a pale straw-colour, from the edge of which against the middle of each hole were sprouted out four small transparent straw-coloured thorns, which seemed to protect and cover those cavities." This is a perfect description of the common Sea-mat. Now the great thing to witness is the coming forth of the living animals from out of these "round-toed shoes," because the polype, as we may call it, which lives in each "shoe," is exquisitely beautiful, and much more interesting than the pretty outside which contains it. By searching for a musselshell, at very low tide, and which has not been handled or.tumbled about, one is often rewarded by finding a crust of these Bryozoa on it, and which present the appearances described above by Hooke. Take it home and place it immediately in pure sea-water, and watch, using a magnifying-glass if requisite. In a few minutes a swelling will appear at the minute hole in each of the cell-like "shoes," and 
a circlet of minute hairs will then appear on a short stalk; each shoe will have one of these, and they become very lively. The hairs or tentacles, as they should be called, all move together, bending here and there, or remain stuck out. There is an evident commotion in the water in the neighbourhood of the circlets, and minute things may be seen in a sort of whirlpool. As there are hundreds of the animals in a square inch, the movement they make is very considerable. Every now and then, if a shadow passes over the water, or if they are touched, the whole withdraw, like jacks in the box, and only the crust is seen. Slowly they come out again and resume their work. Day by day and night by night this goes on, and the creatures grow and the crust increases in size. Should the animal be more carefully examined, it will be found that each of the tentacles is covered on its sides by strong cilia, or hairs, and it is their movement that produces the currents in the water. The mouth is in the midst of the tentacles at the bottom of the circlet, and it leads to a gullet and stomach. They are not insensible to the effects of a "drop of drink," for when they are well expanded and in full work, a drop of spirits of wine and water may be added to the sea-water, with the result of producing more rapid movements. Add other drops slowly, and at last the little beautiful circlets will become motionless, too tipsy to get home again, and they remain outside, and are dead. The animal may then be placed in a proper apparatus to be observed, year after year, under the microscope. The "shoes," or separate polype-cells, in some kinds, have the 
animal protected by a trap-door, and in others by a close fringe of hairs; and the cell may be flat, as in the sea-mats, or tubular and tall, and not over close, in some others, which deserve, especially, the term Moss Animals. The inside of the cell is lined with a delicate skin, and there is a connection between the skins of all the cells, for they are symmetrical in their growth.

Although all the hundreds of minute polypes of the Sea-mat can shut up at once, yet there is much independence of action in each. It is probable that there is a kind of general circulation throughout the whole, and that there is a nervous connection also. The inside anatomy was studied years ago by Dr. Arthur Farre, F.R.S., who discovered, on the coast of the Isle of Sheppey, some tubular moss animals, which he named, after Mr. Bowerbank, Bowerbankia. They had the circlet of ciliated tentacles like the animal of the common sea-mat, and a set of muscular fibres which were attached to it and to the tube inside, so that when they shortened or contracted, the circlet was pulled in, but not directly, for it was turned in as well. He noticed that the tentacles were hollow and stiff, and that the mouth in their midst led to a long gullet. The gullet ends in a small muscular part resembling a gizzard. This opens into a large stomach ; and there is a gut, which strangely enough is bent up, so that its vent comes out within the circlet of tentacles, not far from the mouth. This digestive apparatus is not simple; for the inner part consists of cells with colouring matter, and probably they act as the liver; next 
to this is a colourless coat of cells, probably secreting an acid for digestion, and outside that is a thin layer, with muscular fibres in it, which moves the food about and causes it to pass along the passages.

The liquid contained in the cavity acts as blood, and as the water goes in readily, it is aërated there. 'The creature has nerves, and well-developed ones, situated in the hollow of the bend between the stomach and the intestine. Every separate moss animal has, then, a very complicated composition, yet they are very humble things. They are of a very old family, for the remains of them are found in very old rocks, and they do not appear to have altered much during the world's history. They have some very curious appendages, which assist in keeping the body clean.

Thus many kinds have a little hollow on their sides, and in it is fixed a delicate hair-like straight whip, which is hollow. These are the "lashers," and they merit the name, for they are in constant motion, thrashing the water over and near the animal, and doubtless keeping off large, and letting in small creatures within the whirlpool.

The other appendages would be most extraordinary, were there not something like them on the starfishes and sea-urchins. They are like birds' heads in shape, beaks and all, and they snap their beaks like angry birds, the snapping being done by muscles. The bird's-head-shaped things have no brains or stomach, but there is a hinge to the lower jaw, if it may be so called. They are placed on a stalk, and they lay hold of anything that comes in their way. They are 
more highly formed than the corresponding bodies, found in the starfishes, but they have the same office.

The Sea-Shore Worms.--Sea, sand, mud, stones, and weeds, and even animals, afford protection and food for a host of worms, and there are no more familiar objects to any one who can search a little on the shore.

If all the worms could be collected together, they would be a very curious assemblage : some would be beautiful, and others horribly ugly; but all are most admirably fitted for their peculiar lives, whether they hunt and devour, or merely swallow sand and mud, with the hope of getting something out of it. At a glance the worms could be divided into sets. First of all there are some with a great many joints in their bodies, but without anything stretching out from them in the form of spines, bristles, or gills. Then the others which have these hairs and spines may be divided into two great groups. In one, a number of spiny, active worms are found, which are wanderers ; and in another, a host will be noticed that have homes built by themselves in the form of tubes or cases, into which they can retreat. All these are found on our coasts, and we shall commence with one without any side bristles.

Most remarkable animals of the sea-shore are the Sea Ribbon-worms, which merit their title, so far as shape is concerned. They all-for there are many of them - have a long ribbon-shaped body, and they have a well-developed mouth, gullet, stomach, and intestines. As if the body was not long enough, the mouth is furnished with a kind of proboscis or trunk, 
which can be pushed out or retracted at will : and as the creatures have to use this, and to lead lives of some danger and pursue their prey, they have the rudiments of some organs of special sense besides; and for worms, an important nervous system. These sense organs are expansions of nerve at the bottom of two little pits in the head part of the body, which are furnished with long cilia. Visual organs, by which light can probably be distinguished from darkness, exist in the form of simple spots of coloured matter, which in some contain a body more or less capable of refracting light. And more than one kind has a couple of tiny bladder-shaped bodies, which are supposed to enable it to hear sounds. These $N e$ mertine Worms, as they are properly called, live in the sea, and are to be found swimming freely, or under stones between tides, or in the mud. Most live free, and many are the terror of the worms which live in tubes, for they pull them out of their houses with the aid of the proboscis, and devour them. Like most worms, they repair injuries which may be done to them very soon, and even bits of their bodies will turn or grow into perfect creatures. They have a most extraordinary youth, which will be noticed byand-by, and they are divided by naturalists into two sets, according to the nature of the proboscis, and whether it is armed with a spike or not.

Borlase's Nemertes was described by the Rev. Hugh Davis, in the pages of the "Linnæan Transactions": — "I laid," says Mr. Davis, "a specimen of this wonderful creature in its own element, in the largest dish I had, with a design to observe its habits and 
manners. It partook, in some respects, of the nature of the leech, seeming, like it, in some degree amphibious, as it frequently in part left the water, and, to the length of a foot or two, extended itself along the edge of the dish, and the table on which the dish was placed. At other times, particularly during the day, it was compactly collected together in a heap, and perfectly still, unless the table or dish was touched, of which it seemed very sensible. This it indicated by a vibratory motion of its whole mass, and by retracting the head and fore-part, which were generally somewhat extended. In the night $I$ also found it coiled in a more lax and diffuse manner, covering nearly the whole dish; but on the approach of a candle it seemed affected and inclined to contract itself, so, that although I could not see that it had eyes, I was quite sure that it was very sensible of light. It frequently assumed somewhat of a spiral or screw-like form, and on one morning in particular I was highly gratified in finding it almost perfectly and closely spiral from end to end. I was forcibly struck with this appearance, as it seemed to suggest the solution of a difficulty which perplexed me much, concerning the manner how such a wonderfully soft, delicate, and seemingly unmanageable length of body could possibly move itself from one place to another." It would appear that "every spiral, by a distinct impulse applied in an appropriate manner, will assist in the act of progression by shifting forward the whole of its amazing length at the same instant, without danger of breaking." 
"The worm is certainly capable of extending itself, without any inconvenience, to twenty-five or thirty times the length that it presents at another period. It, moreover, has a proboscis, which can be protruded from the mouth for some eight inches.

"It varies very considerably in colour as it contracts or extends itself, changing from a dusky to a reddish-brown; but it has, when placed in a strong light, especially in the sunshine, a gloss of a fine rich purple all over: when most contracted, it appears nearly black."

This and another specimen were found near Beaumaris, at the time of spring-tide, in the month of March.

"The Nemertes is extremely liable to be broken, and its fragments retain their vitality for some months after their separation from the rest of the animal."

The weapon of this extraordinary worm is of course the proboscis, which is supplied with muscles and elastic tissue; but it has no spikes or little daggers in it, as is the case with some. The worm has a "water system," or a set of conduits within the body, forming two main vessels down the sides, from which branches are given off; and probably there are pores or openings from them into the substances of the body, underneath the outside skin. In some of these worms there is also a closed set of vessels, which seem to have to do with the circulation of the blood.

When first born, these worms are sent forth, from the body of the parent, as little soft eggs, covered with moving hairs or cilia, and gradually the top of each 
grows into the shape of a policeman's helmet, the space where there might be a plume, being occupied by a long set of waving cilia. The cilia are also found on the sides of the helmet, near the edges, where there are lappets. The mouth is, of course, under the helmet, and it leads to a cavity like a bag. It swims freely, and twirls about, and catches food with the cilia around the mouth, and is as little like its parent as is possible. After a while changes occur in the neighbourhood of the stomach and mouth; for the outside skin makes a fold inwards, and then a quantity of cells collect all round the stomach and these folds, and soon a long round-headed thing is seen there. The creature with the helmet lives on, and the one inside grows something like a very small parent form. It embraces the stomach of the helmet larva, and finally falls out, carrying the stomach with it as its own, and its protector dies. The helmet acts as a sort of nurse to the Nemertes, which, as soon as it is free, begins to live like its parents. In reading of this wonderful change of shape during growth, one is reminded of the changes that occur in insects, where the butterfly so little resembles the caterpillar; and it will be seen further on that other animals have corresponding alterations during their lives.

The Sea Mice are not quadrupeds, as their name might imply, but worms ; and certainly, at first sight, they do not resemble those crawling things. They are wandering worms, and have no tubes or burrows, and they crawl slowly or rapidly as the case may be, swim well, and hide up where they can, on the shore. They are frequently cast up, high and dry, after a high 
spring tide, and they also swim between tides, and get into deepish water, falling a prey to the codfish in particular. The old and excellent naturalist, Linné, saw them under water, and was impressed, as indeed everybody must be, with the splendid brilliancy of the creature. He wrote:- "Reflecting the sunbeams from the depths of the sea, it exhibits as vivid colours as the peacock itself spreading its jewelled train." Their shape is peculiar.

The body of the largest is from 5 to ro inches in length, and is of a long flat egg or oval shape, with the ends coming rather to a sharp point. The back is somewhat rounded, the belly is flat, and there is a head joined to the body, and two feelers. A short, thick brown fur covers the back, especially towards the sides, interspersed with long bright green and yellow iridescent hair; and intermixed with this are cross rows of long, stiff, thorny brown bristles. Nothing can exceed the splendour of the colours which ornament these pretty things; they yield indeed in no respect to the most gorgeous tints of tropical birds, or to the brilliant decorations of insects: green, yellow and orange, blue, purple and scarlet-all the hues of Iris play upon them with the changing light, and shine with a metallic glitter only comparable to that which adorns the breast of the humming-bird. ${ }^{1}$ Although called a sea-mouse by the un-scientific, worm-wise men have compared its beauty to that of Venus, and one of her names, Aphrodita, has been given to it. But it is not for their dazzling beauty, merely, that the bristles or setæ

1 From a description by Baird and Rymer Jones. 
of the Aphrodita are remarkable; they can be used as weapons of defence, and exhibit a complexity of structure far beyond anything to be met with in the hairs of higher animals. In one kind, which is called the Porcupine Aphrodita, they are perfect harpoons, the point of each being provided with a double series of strong barbs; so that when the creature erects its bristles, much more formidable than those of the porcupine, the most determined enemy would scarcely venture to attack it. The bundles of bristles are all capable of being withdrawn into the interior of the body, by the aid of the muscular tube from which they spring. This arrangement is particularly useful in preventing the creature from wounding itself, and it is a necessary one, for it is evident that by every movement of the creature's body, they would be inextricably forced into the surrounding tissues.

Hence every barbed spine is furnished with a smooth, horny sheath, composed of two blades, between which it is lodged; and these closing upon the barbs when they are drawn inwards, effectually protect the neighbouring soft parts from laceration.

The head has two flexible antennæ or feelers, about half an inch in length, and there is a row of little prominences furnished with stiff bristles, bordering each side of the body, serving to aid the progress of the worm on land and in water.

The Porcupine Sea-mouse is smaller than the other, and is not so brilliant in its tints. It is found on the southern coasts in places like Weymouth and Falmouth. It has eyes fixed on to the head, jaws, two above and two below, and a proboscis. 
Like the rest of the wandering or erratic worms, the favourite retreat of the Aphrodita is under stones or shells, where it adheres, in a reversed position. It is extremely timid, roaming abroad at night, apparently in search of prey; but it always quits its retreat cautiously. When in confinement in an aquarium, the worms are sluggish, they rarely stir about, but always seem in a languid state, remaining nearly in the same position, with the end of the body bent back, and discharging a constant stream of water from an orifice near the hinder part of its back, with so much force that a slight vortex is formed in the surrounding water. The movements of these Aphrodites, when they choose to exert themselves, are, however, very swift, and half running, but they likewise swim with great facility, passing rapidly through the water. The Aphrodita most probably preys upon living animals, and it does not spare its own species.

There are other worms, of this tribe, to be found on the southern shores especially, and whilst some may be got at low tide, others nestle amongst shells where the water is always rather shallow. There are some which are called Scale-backs, and they differ from the Aphrodita in having the scales and feet bristles differently arranged. One, the Rough Scalc-back is never much more than two inches in length and a quarter of an inch broad. It moves slowly, when by itself, but if its prey is in the way, or it is disturbed, it can run quickly, although it does not swim well. It does not like the light, and quits its haunts of a night cautiously, for it has to look out for sharp- 
eyed things to prey upon, and sharp-eyed things are on the look out for it. The colour is brown, and there are twelve pairs of scales which overlap slightly on the back, and the head is completely hidden by the first pair; but when exposed it is seen to be red, and to have four eyes. It has twenty-five pairs of feet and golden yellow bristles on them, and as there are 270 beautiful bristles to each segment or part of the body, and as there are 25 pairs of feet, there are nearly seven thousand of them on the body of each worm.

The last of these Aphrodites, or Scale-backed worms, which is to be noticed, approaches the common shape of the worm tribe, for it is long and narrow, but it has numerous scales, which occur on the same feet as the bristles. One of these was eight inches long, and was called by Dr. Johnston the Boa-shaped Sigalion. With a body only a quarter of an inch in breadth, r40 scales on its back, and hosts of feet, it was sluggish in a basin of water; but when some sand was put in, it burrowed immediately, and with great rapidity, being assisted by the numerous feet.

The Sanguine Eunice far surpasses all other kinds of worms found on our shores, in size, and it is sometimes two feet long and as thick as a man's finger, the body having as many as three hundred joints or segments. The colour of the body is deep green, and the gills on the feet are intensely red in colour. These tiny lungs are comb-shaped, and are placed on the back of each foot. But although these are the common colours, they differ according to the places where the worms live. When they are found in the 
clefts of rocks, living in a sort of gallery which they make for themselves, they are richer in their tints and are adorned with metallic and iridescent hues. If taken amongst sea-weeds, and the plants called Zostera, on a muddy shore, they partake somewhat of the dull colours of their residence, are less brilliant, and of a darker hue. They have a tremendous masticating apparatus, and there are no less than three pairs of jaws which are solid and horny, and one pair has teeth on it. There is a proboscis, and a lip on which the jaws rest. It is a terrible foe to small living things, dashing its length along, out of its retreat, and seizing with its proboscis, before the crunch of its jaws comes into action.

Some kinds of worms, closely allied to this one by having many points in their construction alike, are not free livers or errants. They, like many others of a different tribe, make tubes for themselves, and live in them. One called the Sao makes a tube of a horny substance, like a quill pen in appearance, being four inches long, smooth, transparent, and somewhat flexible, Dr. Johnston writes about the Sao: "One unceasing object of its life is the capture of prey. For this end it must protrude the anterior portion of the body beyond its tube, and raise itself to the surface of the mud, and remain in this position on the watch. To enable the worm to do this with ease is, I conjecture, the office of the forceps-like bristles of the feet; with their ends it may hook itself to the rim of the tube and thus obtain a support without the waste of muscular power. A long watch is thus rendered less tiresome, while at the same 
time the ability to seize upon a passing prey is increased. The prey caught, analogy leads us to conclude that the worm will instantly retreat and sink within its tube, where it can feed without disturbance or fear. But as the entry and the passage are narrow and unyielding, it seems to follow that the prey should be held by the mouth alone, when in the act of being dragged within the tube, and hence surely the reason why the mouth has been furnished with hard tubercles to the lips; for when pulled together and put in contact they must give a firmer gripe and hold, than could otherwise be taken. The use of the tube is to protect the body from the pressure of the soft mud, in which it stands immersed. When the tube is overset or cast out by the waves or accident, the worm leaves it and becomes, in its turn, exposed to enemies. To protect itself from these while a new tube is being secreted, nature has amply furnished the Sao with a series of bristling lances on each side. These arms are of exquisite make, very fine and sharp; and those of the upper bundle have their points bent and inclined towards those of the lower bundle, which are likewise bent to meet them. Arms like these will inflict wounds on the tiny assailants of the Sao, sufficiently painful to repulse them, and a tube around is unnecessary."

It must be understood that the body of all these worms is made up of a number of rings or segments, which are very much alike except at the head. On each of the rings, at each side of the body, are the various weapons and other structures which have already been slightly noticed. These side structures are 
divisible into two sets,--one nearer the back, or the upper; another nearer the front, or the lower ; so that really there are four, two being on each side to each joint. Take the upper set first. Over the projection of the segment which forms the base of the structure, is a tuft of branching threads, which are often of a brilliant scarlet colour. They spring from a few roots, as it were, and they branch and rebranch like a tuft of the finest red sea-weed; and under the microscope further branchings may be seen. In some worms a single stem comes off and divides into side threads, and in others flat leaf-like pieces of tissue occur there. These are gills or "branchice," and they are made up of branching blood-vessels, protected by a sort of delicate outside tissue. The blood circulates through them, in contact almost with the water in which the animal lives, and becomes purified; they are therefore a kind of lung.

The other structures are called oars, one set being with the branchiæ and the others beneath, and separated by a space. Each set has a fleshy stem which gives origin to a cirrus, which is sometimes a long and slender piece, or is like a paddle at the end, and very small. Besides this, there is a group of stiff hairs which can be pushed out or taken in to a sheath, within the body; and when they are all out, as each segment moves in graceful undulation, a fine swimming or rowing apparatus is seen to exist. 


\section{CHAPTER VIII.}

The Shore Worms continued-The Nereides, their proboscis; the Laminated Nereis, and its breaking-up and reproduction - The Pearly Nereis, the Pelagic Nereis-The White Ragworm - The Lug - worm, its anatomy and physiologyThe Spirorbis-The Serpulæ-The Sabellæ-The Cirratulus-The Chætopterus.

The Sao just noticed belongs to a tribe, many of which do not form tubes, and, indeed, it produces this defence by secreting a sticky mucus from the body, which enables the sand to stick together in the form of a tube around the animal, and separated by a film of the slime. As has been noticed, the whole body is rarely introduced, except on indications of danger, and in order to devour. Others of this tribe, called Nereides, are to be found in old shells, and they may be looked for under stones, and in cracks in them, in cracks in the sand, and some get in between the crevices of sea-weed roots, as well as into sponges. They are a wary set of hunters, and move well in swimming, and crawl by extending the front rings of the body, and bringing up to them the hind ones, all this being assisted by the oars. They get into soft sand, and burrow quickly, and always move head first. Having often specks which are called eyes, these worms distinguish external 
things; but when in the dark, as in the sand, their fine sense of touch, assisted by all the delicate structures on the outside of the body, enables them to feel the presence of their prey. The tips of the structures are intensely irritable, and the result is, that these worms get out of the way of impediments in a nost wonderful manner, and as if they had eyes everywhere. They kill and eat their fellows and many small things, and their weapon of offence is very peculiar. The opening of the mouth leads to a goodsized bag, which is furnished on the inside with hooks and spines, and sharp-cutting plates. This bag leads down to the stomach. Now, suppose a small creature is passing near the worm, it darts towards the prey, and touching it with the head, immediately turns the bag inside out, and sticks it beyond the mouth. By doing this a proboscis is formed, covered with sharp things. These catch the prey, and then the bag is turned in again, and the victim finds itself tucked in, surrounded with an apparatus which chops it up, and then it passes into the stomach.

One of the finest of these worms is the Laminated Nereis, and it is sometimes 2 feet in length, the body being made up of 400 segments, each of which has a pair of broad paddles on its sides. It is of a fine green colour, bluish-green on the middle of the back, iridescent, and reflecting a bright olive tint. Its paddles are green. It lurks in the daytime, hiding up under some large flat shell in the water, but at night it unfolds its length and starts forth to hunt.

In confinement, these magnificent Nereids can seldom be preserved entire. Their body, unmanage- 
able on account of its length, without ample space wherein to perform its evolutions, is exposed to frequent entanglement amongst surrounding objects, and is often broken by the creature's struggles to get free; yet, wonderful to state, even this is by no means an irreparable damage. A specimen kept by Sir John Dalzell, measuring about 22 inches in length, was mutilated by the loss of some of the hinder segments of its body during the month of October, and in eleven days the missing joints had been regenerated. But on the 22 nd of January the body of the same worm broke asunder, near the middle. Within three weeks the wound at the hinder extremity of the anterior portion healed, and in the month of April above fifty segments with their paddles had been reproduced. The whole of the newly-formed portion was of a pale green colour, but its breadth did not exceed a third of the width of the original.

Many kinds called Nereis are found on our coasts. They, perhaps, are the most common members of the worm class. We can scarcely turn one of the flat stones which lie half-buried in sandy mud at the water's edge without finding one or more of the tribe. The Pearly Nereis is one of the finest, as well as the commonest of them all. "The upper surface," says Gosse, describing from a living specimen, "is of a warm fawn-brown, but the beautiful flashes of iridescent blue that play on it in the changing light, and the exquisite pearly opalescence of the delicate pink beneath, are so conspicuous as to have secured it the title of 'pearly.' As you gaze upon it you see 
the great dorsal vessel or heart, as a dark red line running along the middle of the back. This, at irregular intervals of five to fifteen seconds, contracts almost to invisibility, and then expands again, taking the form of a string of beads in each process. This, howerer, is only a part of the great circulating system in this fine worm. In it the red blood flows from the tail towards the head. At the under side of the body there is a similar vessel (the ventral), through which the blood flows from the head towards the tail. Besides these, there are four other longitudinal vessels in the interior of the body, one above and one below the intestine, and one on each side, all of which are connected by transverse branches."

The Pelagic Nereis is another very common British species, and in general appearance resembles the one just mentioned. It reaches the length of nearly six inches, sometimes even more, and is of the thickness of an ordinary goose-quill, tapering towards the tail. The body is decorated with rather a brilliant hue, of a flesh-colour, with more or less iridescent metallic or olive-green reflections. The proboscis may be easily seen in this species.

This wandering species is found abundantly, burrowing like an earthworm in soft seaweed and in mud in brackish water; so that, as it is likewise found in great numbers on the shores in various parts of our coasts, it is not a species which is confined to pure sea-water.

The worms belonging to the genus Nephthys, found on our coasts, are known by having a small head, furnished with four minute antennæ, and a large 
ciliated proboscis, with a series of papillæ at the orifice, which is of a longitudinal form. The segments are all provided with large feet, which consist of two branches, placed wide apart from each other. These organs have each a lamelliform process in front; and pendent, underneath the superior, there is a considerable-sized branchial apparatus of a curved form, like that of a sickle or reaping-hook. The setæ which spring from these feet are slender and setaceous, and are both simple and compound.

One of the species, the White-rag Worm (Nephthys caca), is a common inhabitant of the shores of Great Britain. It varies from 6 to 10 inches in length, is $\frac{3}{10}$ of an inch in width, and is of a beautiful pearly lustre. The feet are much developed, and increase gradually in size till they, reach about the middle of the body, when they again decrease as they extend down towards the tail. This worm has a colour, which is exactly similar to that of motherof-pearl. This hue extends some distance down the back and belly, but the feet are of a yellowish tint, with their inner base reddish, and the bristles dusky.

The White-rag Worm lives in the sand, burrowing into it by means of its strong proboscis, and it buries itself with almost incredible velocity. Nor is it less active in the water, should it be accidentally removed from its burrow and cast in the open sea, for it swims rapidly, with a serpentine, wriggling motion, being propelled by the lamellæ, which project from each side, like a double bank of oars.

Every visitor to the sea-coast must have remarked certain places on the shore, near low-water mark, almost 
entirely covered with little pyramids or mounds formed by coils of sand or mud, the "castings," as they are called, of worms. All these little heaps are produced by an animal lurking, at a considerable depth beneath the surface, and known by fishermen, who find in it a valuable bait, as the Lug-worm, or the Lug. There can never be any difficulty in procuring specimens of these worms, if only care be taken to dig deep enough, the spade being driven to the depth of at least a foot and a half into the sand, otherwise the animal will certainly be broken.

When dug up entire, this worm is found to be about ten inches in length, of an invisible green colour, and in some parts nearly half an inch in thickness, its body being long and round, and made up of many joints or segments towards the end. There are thirteen of the joints which are furnished with gills, and there are six near to the head which carry bunches of fine bristles. These are in a double row, and project from the sides of the animal; and the thirteen tufts or gills are vermilioncoloured and rise from the back, commencing at about one-third of the length from the mouth. The tufts or gills act as the respiratory apparatus or lungs, are very elegant, and when examined with a simple magnifying-glass resemble arborescent shrubs, the stems, boughs, and branches of which are all in lively movement.

The Lug is extremely impatient of light, and when in confinement, continually attempts to penetrate downwards, even when there is no sand in the vessel, but if amply provided with this material, it soon screens itself from view. 
A sticky, viscid secretion exudes from the fore part of the animal, to which the sand adheres, and hence, when the worm is dug up, part is generally found to be covered with an imperfect sandy tube, within which the movements of the worm are performed with perfect freedom, but which cannot be removed entire, on account of its extreme fragility. This tube is, in fact, left behind as the animal moves off, and forms a complete lining for the hole, which, like the brickwork of a well, it supports, and keeps pervious throughout its whole length. 'The creature is thus enabled to ascend readily to the surface, and the water is admitted freely to the tufts or branchiæ.

A few of the front rings of the Lug diminish gradually in size, and each admits of being completely folded within the ring immediately behind it. Hence, when they are fully drawn in and retracted, the fore part appears abruptly shortened; while it is prolonged in the shape of a regular cone, when they are stuck forth. This constitutes its boring apparatus. The rings being retracted, the flat head of the Arenicola is directed against the sand, and then the forcible projection of the cone opens a passage for the rest of the body. The opening thus made would, however, be insufficient, and the delicate branchiæ might be injured while forced through such a narrow passage; but, to avoid this, the animal immediately on completing the penetration, distends the penetrating rings very considerably. ${ }^{1}$ By the advance of the body, the opening thus enlarged, is then occupied, and

'Rymer Jones, Aquarian Naturalist. 
the rings being again received into each other, the cone is ready to be again projected. It is not, however, simply for the purpose of excavating a retreat that the Lug thus works beneath the soil - the sand, amongst which it works, is devoured and swallowed as the worm bores its way: not that the sand itself is nutritive, or can be used as food, but the organic matters mixed up with it are thus made useful, and become assimilated as the earthy medium traverses the stomach and intestines, and it is finally rejected in the form of the coil, on the surface of the shore.

Living head downwards, in a burrow lined with sand stuck together, and about two feet deep, it chooses its home near low-water mark. They are readily caught by the fishermen, and as they form excellent bait, they are continually and systematically dug up.

Other worms of the sea-shore, which, instead of being wanderers, like most of those already noticed, are always found at home in a tube-shaped house of their own. They are found in the sand, on sea-weeds, on old shells, and stones, and some are large and others are minute, but nevertheless their number is very great.

The first to be noticed is extremely common, and, indeed, it is to be found on sea-weed, sprinkled here and there in numbers. The tube or home of the worm is more commonly seen than the worm that lives or did live inside, and it is white, about the size of a pin's head and is coiled up flat like a single coil of rope, and it adheres to the weed. From its spiral twist and round outline, the 
worm has been called Spirorbis (page 4I). The worm lives inside and makes its tube, which is of carbonate of lime, like a shell, and possesses a trap-door, which covers it in like a lid. But this is made out of one of the feelers or tentacles of the creature, near its mouth; it is in the form of the rounded end of a knife. When the door is shut, nothing is seen but the white shell; but as it opens, some tufts appear, like fine feathers in a circle, and they gradually project and come out of the end of the tube. On the passing of the least shadow or an unusual movement of the sea in the neighbourhood, the feathery-looking gills or branchiæ, for such they are, disappear by being withdrawn and the door closes again. The feathery structures produce currents in the water and bring minute prey to the worm, and it is from out of the carbonate of lime of their tiny coats and shells that it builds up its house.

Larger than these worms are others, which are excessively common on old shells and stones, but which are tubular, long, and more or less curved, or straight, bent, or crooked. Sometimes one may be seen straggling for three inches or more on an oyster-shell; it is stuck fast by the side on which it rests to the shell, and is small at one end and large and open at the other. On the other hand, these tubes often accumulate together, and form a bunch, all with their openings in one direction. The tubes are much longer than their inhabitants and makers; and as they grow, the tube is enlarged and lengthened at the top, where it is largest.

The worm lives inside, and is called Serpula; it 
never leaves its home, and has a trap-door, feathery gills to breathe with, and an apparatus to drag it back quickly into its tube when alarmed. Although it is a worm, and lives on small things, which are wafted into its mouth and stomach by currents of water, it is exquisitely beautiful in its colours, and in the graceful arrangement of its necessary structures. Inasmuch as the Serpula never leaves its home, and only puts forth its head out of its shell, the breathing organs, instead of being all down the body on each segment, as in the active, predacious and wandering worms, are all close to the head. Ever-economical nature transforms one of the feelers into a trap-door, gleaming with lovely colours, and graceful in its long conical shape. As if to render this pretty and necessary structure all the more apparent when it is not in use, the lungs are in the shape of broad fans, in halfcircles, with feathery-looking endings. Really the fans are made up of filaments placed side by side, like a close comb, and each of which under a slight magnifying power consists of a pellucid gristly stem. From one side of each, a double set of smaller filaments arises like the feathers of a pen. On the beautifully-coloured outside-all pink, red, scarlet, and yellow-are countless cilia, large and strong, and fully able to make a current by their movement; and so perfectly are they arranged, that the motion in the water is upward along one side of the filament, and downward on the other. These currents in the water, bring fresh water in contact with the fan-shaped gills, so that the blood of the worm may be purified. $\Lambda \mathrm{nd}$, indeed, the microscope reveals that there is an 
artery and vein in each of the filaments, along which the blood passes regularly to be aërated. Moreover, the cilia are most important in nourishing the animal, for the currents they form, carry the minute particles and creatures on which it preys down the funnel, made by the roots of the fan and the trap-door, to the mouth. When the creature is irritated, the gills are pulled in within the tube, and the top of the trap-door locks, and fits the opening exactly. These worms do not go into their tubes slowly, but with rapidity; and this is done by a special apparatus.

The worm has of course the so-called feet of others; but they are modified for its peculiar life. On the upper part of each foot, extending half across the back, is a row of microscopic hooks, wielded by long thread-like tendons, which are fixed, writes Dr. Baird, ${ }^{1}$ on mechanical principles, to the attached end of each hook, Mr. Gosse says that these organs (hooks) are formed on the model of a hedger's billhook, only that the edge is cut into long teeth. "Carefully counting them, I have found that each Serpula carries about I,900 such hooks on its corslet, and that each of them being cut into seven teeth, there are between 13,000 and 14,000 teeth employed in catching the lining membrane of the tube, and in drawing the animal back. To end the description of this remarkable worm, the feet on the hinder portion of the body are unlike the others, and are made so that they clean out, mop, and scrape the small end of the tube in which it lives."

1 Dr. Baird, "The Annelid Worms," 7\%e Student, No. I7, I869, p. 334. 
In some of the creeks and rivers of the east of England, just within the range of a very low spring tide, are found great masses of tubes from a foot to fifteen inches in length, each tenanted by a worm which has a most gorgeous head-dress. The tubes are tender, may be bent, are cylindrical and smooth outside, and are made up of mud or sand, united by a sticky secretion. The materials for these tubes are ready made, and are collected by the worms and fashioned into one particular shape; they are not composed of carbonate of lime, and deposited in the outer tissues of the body by a vital process, as in the Sespula. The worm now under consideration is called the Fan Sabella, and when one is placed in an aquarium, it gradually pushes forth a most beautiful double circle or scroll-shaped gill, open widely at the end, and leading down into a funnel-shaped passage. The colours of these elegant fans are very carefully arranged, so as to give an artistic symmetry and design, which is indeed marvellous.

Many of these sedentary worms are noticed on all sorts of substances, and their tubes are made up of visible tiny stones, pieces of shell, and mud, and are very fragile. Sometimes there is a collection of the tubes in a group ; in other instances a flat tube is on a shell alone. All these tubes have a delicate silky lining like spiders' web. Rymer Jones says that they are made by a little Sabella, the length of which is rarely more than three-quarters of an inch. The head is provided with numerous filaments, about eighty in number, and they are very flexible. The body is round, and composed of numerous segments, some 
of which are provided with numbers of bristles, and there is a curious sort of tail end which can alter its shape. They are lively things, and they testify, writes that author, "a decided predilection, while choosing the materials for their habitations, always preferring sand and broken-up shell. But there is a striking difference in the character of the tubes: one is short and confined, giving little beyond mere accommodation for the body, while another is considerably prolonged, so as to afford a safe retreat in time of danger. The architect of a third seems to persist in advancing the fabric as long as it can procure materials, and never seems weary of working. Night is the chief season of this architectural labour, though the worm is seldom guilty of perfect idleness."

The last set of worms to be noticed belong to the Tube-makers, but the kinds have not the beautiful head fans of the Sabellas, and they have no stiff bristles on their body-rings, or segments. The head of the creature has a multitude of long, thread-like feelers about the mouth, and the gills are branched, and are restricted to two or three pairs in number. Their tubes, cylindrical in shape, and open at the ends, may be seen between half-tide and low-water mark, sticking out of the sand among the rocks and stones of the shore. Some end in a tuft, like a ragged cord, and on search being made in the neighbourhood, a plain opening of a tube may be seen. They may wind about in the sand, and it is possible to remove them with the worms within. The nearly or quite one hundred feelers and the brilliant scarlet tufts and the gills, 
cause the animal to be recognised at once. It is of a pinkish colour, and has a carmine band along the body. Rymer Jones writes: "If a specimen be dislodged from its tube, it swims by violent contortions in the water, after the manner of various other marine worms. The feelers and the branchiæ are compressed and contracted about the head like a brush, and as the animal becomes very soon exhausted by such unnatural exertions, it soon sinks to the bottom. Should a quantity of sand be now scattered from above, the feelers, speedily relaxing, extend themselves in all directions to gather it up, sweeping the ressel quite clean, so that in a very short time not a particle is left behind, that is within their reach, the whole having been collected to be employed in the construction of a new artificial dwelling adapted to shelter the naked body of the architect." A silkylooking lining is added to the inside of the tube, and, as in the other worms, intentional or accidental injuries to the body are repaired in a wonderful manner. This worm has been called the Sand-Mason. Another of the same tribe has very long feelers, and is called the Potter; and in making its tube, some substances come from the mouth to be added to it ; and, indeed, it seems that most of the materials for the tube are swallowed first of all. The tube is rather massive and clumsy, and may be half an inch across ; it is fragile, and usually constructed upon some substance, for it cannot stand erect. The Shell-binder constructs a tube entirely of broken shell, lining it with a silky secretion; they are large worms, and are most numerous about midway between high and 
low-water mark, where the sand is mixed with a large proportion of stones. The long tubes permit the worm to remain at their lowest end until it requires food. The Weaver, so called by Sir J. Dalzell, is small, and not more than an inch and a half in its greatest length. It builds a sheath of sandy or muddy particles, not large enough to contain the whole body. It leaves its sheath to make another if requisite. But the most extraordinary part of the lifehistory of this worm is, that it makes a cobweb of threads so fine, slender, and transparent that they are hardly visible. The web is very thin, and is used to cover and hold the spawn, and it has its outlying threads like those of the web of the spider; but how it is made is not known. Finally, there is a worm belonging to this set which seeks holes and cavities in oyster-shells, lines them with silk, and hides up. It protrudes its feelers, which seek all around for prey. There are many worms which are not exactly homemakers or sedentary or wanderers, but which are movers in wet sand and mud, or dwellers in slightlycemented sand-formed tubes. They appear to have the outside organs of motion of the wandering worms, and the hooks of the others. There are some of these worms which have the general shape of the earth-worms; and the gills or branchiæ, instead of being beautiful tufts of branching vessels, are long, thread-like, straight, or tortuous things placed on the back or margins of the joints. The feet are small, and form a double set on each side of every segment, and these are numerous and narrow. Usually the head has no tentacles on it. 
One ${ }^{1}$ of the most common species on our shores is the Northern Cirratule (Cirratulus borealis), found on several parts of our southern coasts, such as Devonshire and Cornwall. It varies from three to nine inches in length. The body is rather less than a goosequill in calibre, and is of a brown or yellowish colour. 'The head is very small, the segments of the body are very numerous, and the branchial filaments are found in greater abundance near the head than on the body. The Cirratulus borealis lurks under stones, in a somewhat muddy soil, in which it forms burrows similar to those of the earth-worm, and into which it retires slowly when disturbed.

Another kind of worm, resembling this last, and found living in tortuous, cylindrical holes, made by the animal itself, in the substance of some of our hardest shells, is the shell-boring Cirratule. This worm is only about an inch long, and scarcely a line in diameter; has no distinct head, but only a cylindrical, obtuse sort of snout. The segments of the body are distinct, but the branchial filaments are few in number compared with the Cirratulus. Its habits are interesting. It lives in a hole or furrow, drilled out of the substance of some of our hardest and most compact shells. The tunnel, so called, fits the size of the body of the animal, and the little creature seems ill at ease and very unquiet when withdrawn from its case. When at rest under water, it protrudes the tentacles and filaments from an aperture which is on a level with the surface. The

1 Dr. Baird, Student, June, x $869^{\circ}$. 
filaments are laid along the shell, and are kept quiet or moved about like independent worms.

Another very curious and interesting worm found on our own coasts, is the winged bristle-bearing Annelide, the Chætopterus. This has also the body formed, as it were, of two dissimilar portions. The Chætopteri are of very considerable size. The head is flat and short, and is provided with two rather long tentacles, springing from its under side and generally channelled. It has no proboscis, but a part of the body is furnished with pinnules, like a pair of wings. The front of the body is of a square shape, broad and flattened. The middle portion is cylindrical, and composed of four segments, which are in the form of sacs or vesicles. The end consists of from thirteen to twenty-three segments, gradually diminishing in size as they descend towards the caudal extremity.

The Chcetopterus insignis, found on our coasts, from the Firth of Clyde to Cornwall, North Wales, and in the Chamnel Islands, is about four or five inches long, and inhabits a thin, parchment-like tube, coated externally with sand and gravel. 


\section{CHAPTER IX.}

The Star-fishes :- The Cross-fish-The Common Spiny Crossfish-The small Cross-fish-The Eyed Cribella-The Common Sun Star-The Brittle and Sand Stars - The Common Brittle Star-The Daisy Star, Points in anatomy-The Long-armed Brittle Star-The Sand Star-The Ser Urchins of the Shore.

A VERY common animal of the shores of every part of the United Kingdom and Ireland is the Star-fish; and it is called by many names, such as Five-fingered Jack, Five-fingers, Cross-fish. In Cornwall they used to be called Cramps, and on some parts of the Irish coast they are termed Devil's hands. Really there are several kinds of animals, comprehended under the proper name of Star-fish, which frequent our shores and live for a while within tide-marks. Probably there are seven which may be called littoral, or shore species; and these, and the several others which live in deeper water, are often cast up after a storm, and lie dead and bruised on the beach. People who travel in out-of-the-way roads in the Eastern counties near the sea, will sometimes pass waggons filled with something which is terribly offensive to the nose; and the manure which is being thus carried to be placed on the land is "Five-fingers." So great is the quantity of these Star-fish on the shore at certain times, that this manure is by no means dear. 
The commonest Star-fish is properly called the common Cross-fish. It has five rays, with a small space between their origin, which is called the body or disc, and the colour is orange or yellow, and sometimes purple. A large one measures more than a foot across, and common-sized ones measure nine inches, or more. The rays, as the fingers are called, are rounded and short; they taper gradually to a point, their length being about three times their breadth. They and the body, when looked at from above, are prickly-looking, and the surface feels hard, and seems as if it were made up of many pieces. Some spines or prickles are at the angles of a sort of hard network on it; but they are blunt, and have many smaller neighbours. On the ray these spines and network form a kind of ridge. Now a good pair of eyes will notice in the midst of this network some small pincers on little props. If some acid be dropped on to the skin, bubbles will form, and some of it will be dissolved, for there is much carbonate of lime in it. One more curious thing is to be noticed, and it is a knob near the edge of the body, just between the origin of two of the rays. It is a pretty thing, marked with many straight and radiating lines, which split in two near the edges. This is called the water tubercle, and is a filter, down which water passes into the creature. As the markings resemble those on Brainstone corals or madrepores, the tubercle is termed madreporic body, but water tubercle will do as well.

Now turn the Cross-fish on its back, and examine it underneath. In the middle there is the mouth, with a number of spines around it, and the finger can 
be passed into a gullet. It will go in a little way into what is the stomach, and will reach on all sides into the rays for a certain distance. The stomach, then, is large, fills the body nearly, and there is an extension into each ray. The finger will touch something hard, that feels like a wire, ending on the upper surface at the water tubercle. This is a tube or hollow cylinder, down which the sea-water passes from the tubercle.

The stomach has a great deal to do for the Starfish, for it is a voracious creature, and it has to grow quickly, and to form its covering and inside, at the expense of its food, like other beings. Much carbonate of lime, colouring matter, muscle, nerve, and mucous tissue have to be made out of the prey, and therefore the digestive organ is large. It has just been said to extend into each of the five rays, and it may be seen that those offshoots are furnished with many little hollow places, like sacs, on their sides, so as to present a large surface. All this surface can digest. This stomach, then, resembles a bag, open below for the gullet and mouth, and with five corners, one for each ray. Now the top,-the bag, has a narrow opening in it leading to a wide second bag, which has also five prolongations, like tubes. Each one of these goes into a ray, divides into two, and they, like the stomach underneath, have tiny sacs. The second bag, and the tubes and sacs are probably concerned in making up the digested material into a fluid, which can readily be utilized in the formation of the tissues. A very small intestine is on the top of this last bag, and it leads to 
a minute opening on the top of the Star-fish, which is the vent, whence come the undigested matters. All these internal stomach extensions, of tubes and sacs, are united to the inside of the shell or skeleton, by tissue. It is wonderful what these Star-fish will eat. Good-sized shell-fish are found inside them, and the animal devours the soft parts, and some of the shell also. Sea-urchins, prickly as they are, are bolted whole and digested, and when a fellow Star-fish throws off one of its rays-a very common habit-a passer-by may get it into its stomach, and enjoy it. Fishermen, fishing with deep lines for cod, ling, and whiting, often feel a tug, and expect a two- or threepounder at least : but up comes a Star-fish, with its arm feelers all in movement, with the worm and hook in its stomach. It is certain that oyster-beds suffer much from the depredations of the Five-fingers, and many have been the theories to account for how a thing without a knife can open an oyster, and get him out of his shell and devour him. Some have thought that the Star-fish watched his opportunity, and put one of his rays between the oyster's shells: but the probabilities are, the oyster would close and nip his enemy. Others believe that there is a poison sent out by the Star-fish which paralyzes the oyster. But it seems that a good-sized Star-fish will place its mouth close to the sides of an oyster, and tuck much of it in, shell and all. By-and-by the oyster gives in, and then he is bolted without the shell. But to do this there must be some power of dragging and pulling in the rays; and if they are examined a little carefully. on the under side, it will be noticed that 
a furrow runs down each ray. On either side of it are rows of tentacles, each ending in a sucker; and when a living healthy Star-fish is watched, these are observed to be in constant movement, and to be strong enough to.pull the animal up the side of a tank. They are long, soft, and very irritable, and there is a tube in them ending in a bag at the free end. When the tube is filled with water, from the water system of the creature, the soft bag may be pressed against anything, and then if some of the water is withdrawn, a sucker is formed. The tentacles are large around the mouth, and they extend to the top of the rays, where there is a curious body, called the eye. It is a little lump of the outside stuff of the ray, which is continuous with a nerve that runs down the groove in the ray. In the lump there are some clear egg-shaped bodies, with colouring matter around them, and they form the seeing organ. The last tentacle is close to the eye, and it has no sucker on it, but it is exquisitely sensitive, and appears to be a very delicate organ of touch.

These tentacles, and indeed the whole Star-fish, have to be kept very clean, and free from sand and mud: consequently scavengers exist in multitudes. Close to the place whence the tentacles come from the arm, are numerous little flexible spines, terminating in a pair of pincers. The blades of the pincers are broad near the spine, and sharp at the end, and they open and shut in a most extraordinary way. Strong muscular fibres are fixed at the hinge of the pincers to pull the blades together, and smaller ones open them. They snap at everything, and hold on 
like bull-dogs. Their duty is to catch dirt from near and off the tentacles and body, and cast it away.

Besides the nerve of the ray, which is continued round the gullet, there is a water-vessel in the ray's groove, and this is a tube. An offshoot of it goes to each tentacle, and there is a little swelling, or bag, close to where it is given off, by which assistance is given, in sending water into, or getting it out of the tentacle. The main tube of each ray comes from a great tube around the gullet, near the nerve, and which communicates with the filtering madreporic body already noticed. Besides these structures, there is something like a set of blood-vessels, whose anatomy has yet to be made out. The blood, or rather watery fluid, with some cells in it, circulates in these vessels. And these "cells" are very remarkable, for they alter their shape in a most extraordinary manner, when they are examined under a microscope.

Another Star-fish, which is commonly dredged up in the western seas of our island, from deep water, gets often into the sand and gravel of the coasts of the Hebrides and of Skye at low water. It likes weedy places, and therefore is rarely seen; but it is distinguished from others by its resemblance to the common Crossfish, and by having strong spines on its rays, which this last has not. This Spiny Cross-fish has four rows of tentacles in each of the avenues which groove the rays below. These tentacles are long, immensely active, and coil and wriggle independently and together in a very curious manner. The animal grows to a considerable size, and may be 33 inches 
across; less than half that measurement is the most common size. It is of a reddish-brown colour, with yellow tufts around the spines, and the stomach is pale green.

It has the power of getting rid of its rays in a marked manner. Living rays have been dredged up without bodies, and bodies without rays. Nevertheless there is doubt whether some accident is not necessary for this casting-off of the limbs. Certainly one Star-fish, called the Lingthorn, can cast off little bits of its rays, or the whole of one or more, without violence being used to it, and fright or a sudden change of water will do it. After losing an arm, or more properly a ray or two, these Cross-fish will grow then again.

A wee thing of a Cross-fish, not more than an inch and a quarter across, with broad and short rays, is usually of a bright rose-colour. It is rare, but has been found on the east coast of Scotland, on the shore of the Isle of Man, on the Ross-shire rocky shores, and on the coast of Down, where its size is much less.

A Star-fish called the Eyed Cribella has the shape of the Cross-fish, but the rays are rounded, and there are two sets of spines on either side of the grooves of the ray, and only two sets of tentacles instead of four. Usually there are five dark spots near the origin of the rays, from the body. The colour is generally dark red, or deep purple above and straw-coloured below. It is a small kind, and there is a curious state of the upper part of the body to be noticed. The solid or spiny skin is wanting 
here and there, and out of a pore comes a soft tissue of a brownish colour. This is part of the inner membrane of the animal. It is rarely found on the shores, except in the far north.

The next Star-fish to be noticed, has a very different shape to the others. It has a large body, and often twelve or fifteen short, spine-shaped rays covered with bundles of spines. The tentacles are arranged as in the last kind. It is very common and handsome. The rays are about one-half as long as the disc is broad, and they are rounded, whilst the disc is flat. The upper surface is covered with knobs, which are arranged in regular rows on the rays, but scattered on the body. Each of these knobs has a bundle of long, needle-like spines, there being eighteen or twenty together. Five rows of these are on the arms. There is a curious protection to the mouth, for the origins of the rays join or bear an oval, or rather triangular, plate grooved down the centre, and carrying two semicircular, long, tapering spines, which project in a comb-like manner over the mouth. The eye is protected by a cross row of spines, which lap like a finger over it.

The colour is very different, according to locality and age. Sometimes the whole of the surface is deep purple; often the disc is red, the rays white and tipped with red, and the knobs may be bright green. Some are white with the exception of the red eyes. They grow large, and reach I I inches across, and are rare destroyers of shell-fish and oysters. They may be got at Scarborough at low tide and at Youghal, in quantities. It is called the common Sun Star. 
The last Star-fish to be noticed as a shore kind, has a different shape to the others, being five-sided, and without rays distinct from the body. It is a small, greenish-yellow thing with a red or brown tint, and is about an inch across. It is very swollen or gibbous, and is covered above with tufts of short, thick spines. This little gibbous Starlet, as it is called, is common in many parts of the south coast, and of the West of Scotland. The other British Star-fish are not found between high and low spring tide-marks, but they live in deeper water.

The Brittle and Sand Stars.-A Star-fish with very long, slender, bristly arms, starting from a small, flat, roundish body, is a popular description of an animal, several kinds of which are found on the shores of many parts of the United Kingdom and Ireland, and which are called Sand and Brittle Stars. The body is called the disc because it is broader than high, and either circular in outline or angular, from some peculiar connection between it and the arms. It is covered wth a skin of scales which are large or small, according to the kind.

There are five arms, which dovetail, as it were, into the disc, and each has two large scales or shields close to its origin from the upper part of the disc. On turning the disc over, the mouth is seen on the under side, and also the prolongations of the arms. Between the arms, on the under surface of the disc, are some slits, one on either side of each arm usually, but sometimes two, and the eggs come out there. The arms are sometimes very long, and in many 
kinds short; and if not bristling with sharp, delicate hard hairs or spines, have a few spines only. Five in number, the arms either look like worms or parts of snakes, from being covered with regular scales, and in some kinds they are rather stiff and do not move much, whilst in others they wriggle from side to side in a most astonishing manner. The creature when taken up, is hard to the touch, and is evidently covered with a hard skin in the form of scales and plates; and its colours are according to the kind, white, gray, black, red, and variegated with all these tints.

Usually they are found dead on the shore, having been washed up by storms; but there are many places where they are to be found alive, when the tide is very low, and in places where the shore is rocky and even muddy. They like rock-pools, and between low spring-tide and ordinary tide-mark is the natural home of many. The rest live in the deeper zone beyond, amongst the ribbon-shaped sea weeds, and in deep water.

A curious kind is common along the eastern coast of England, at low water in pools, and on rock and sand, and it is called the Common or Red Brittle Star (Ophiothrix rosula). A very wriggling thing it is in the water, for the five long, hairy, spiny arms move like active Hundred-legs, Snakes or Worms, and the little round body, covered with spines, is danced about here and there. Beautiful in its colouring, rosy red, red-brown, splashed with white, or spotted with dark-red tints, often marked with a yellow star, and occasionally black, the disc is often flat, or sometimes swollen, and yellow-looking between the 
ray-like arms. The arms are white or gray, banded with bright pink; they are often of a deep blue, with rose-coloured spines, or banded with bright yellow, or speckled with brown or orange. The spiny hairs have sometimes brown tips and blue bases. Hardly any half-dozen specimens are alike, so variable is the colouring; moreover, the size of the creature differs, probably according to its food, and the arms are longer in some than in others.

There is a very curious gift possessed by the creature, which is not altogether peculiar to it, however, or to its fellows. Touch it suddenly when it is in the water, and it will fling off an arm. Take it out of the water, and squeeze it in the slightest degree, and in a moment the body alone is left, and all the arms drop off, and are seen wriggling about for a while by themselves. It is the very essence of brittleness, and hence it and the other kinds which do this sort of dismemberment have been called Brittle Stars. If they are kept in plenty of salt-water they will thrive for a while, but as the water becomes impure, and less filled with airbubbles, they throw off joint after joint of their arms in a most unconcerned-looking manner. Under favourable circumstances, the arms grow again, for specimens are frequently found with them in a condition indicating new growth.

Another kind is called the Daisy Brittle Star (Oplizopholis bellis), and is to be found on the Scottish shores, and is abundant in the deeper water at a few fathoms below low spring-tide mark, in Orkney and Shetland. It has been found in Cornwall, and under stones at very low tides at Scarborough. Probably it is only 
to be got by dredging in Dublin Bay, and near Belfast. The northern specimens are larger than those found to the south, and those most commonly seen have their pretty, red-coloured disc about three-quarters of an inch across; the arms, five in number, being not more than three times its breadth in their length. These slender members have short, stoutish spines stretching out from them at each joint, and are red like the body, but they are also banded with yellow cross-stripes, or with a duller red. The body on the top is often remarkably variegated in its tints, for it is covered with very symmetrically arranged scales, the larger ones being of a lighter tint than the others. A plump-looking body, with its scales arranged in beautiful orders of groups of five, is made all the more interesting, because Nature has employed vast care in its ornamentation. Between each of the larger scales there is a row of much smaller ones, which are rather spiny, and all the mosaic pattern of the disc is thus rendered more visible by this extra pattern. The same idea is developed on the arms, for there each armplate, on the top, is surrounded by a number of small rounded, or longish scales, giving a wonderful finish to the whole. The arms taper gradually, and there is a hook or two on either side of them, close to the top, besides the spines. They move from side to side, and do not wriggle as much as those of the Rose Star just noticed, but they clasp a little, and the young Daisy Stars cling on to the old ones often, the hooks being then of considerable service. The arms, when examined with a lens of low magnifying power, are found to be made up, as in all these animals, of four 
outside scales or plates, one above, one below, and two at the sides, to each joint, and there are very many joints. The spines of the arms stick out from the side-arm plates, and just where these plates join the under-plate there is a hole (one on each side of the under part of the arm), out of which comes a longish finger-shaped tentacle, fleshy and soft, and capable of moving its tip, and of being withdrawn into the arm. There is no sucker on the end of it, as in the tentacles of the Star-fishes, and it can only be useful to hold on with to a certain extent.

A Brittle Star, with exceedingly long arms, some eighteen or more times longer than the little body, has the very proper name of the Long-armed Brittle Star (Ophiocnida brachiata), and it has been found on the shores of Cornwall, in Belfast Bay, and especially in sand in one particular part of Salcomb Bay, where that substance is collected for manure. "The only perfect specimens," writes Edward Forbes, "were such as had died in a heap of the sand. In any other way it would be impossible to kill them without breaking them into pieces from the extremely fragile quality of the arms." The great observer of nature, Montagu, noticed that there were three or four hundred joints to each arm, and that eight or nine spines were in a row at every joint, so that this little star, with a purplish-brown or blue-ash colour, has in its five arms no less than one hundred and forty thousand plates, scales, ossicles, and spines, and probably, if everything was counted, there would be nearly one hundred and fifty thousand pieces.

The Sand Stars have snake-shaped arms, with the 
spines small and close to the body, and the common one of our coasts, rarely found, however, likes the sand. An old naturalist, Réaumur, believed that they were so fragile that they could only live in the soft sand, but really they are stronger than the Brittle Stars which live on and about rocks, often enough. The disc or body is round, short, and covered with small smooth scales, and opposite to the insertion of the arms are two triangular radial shields separated by two smaller scales. The arms are long, tapering, and rather keeled above, and their scales are broad and narrow. There are some minute spines on the edge of the disc, and the arms carry seven short spines closely placed on them. The body is nearly an inch across, and the arms measure about three times its length across, so it is a fine Star. It is reddish on the disc, marbled with purple-brown, and the sides are white, and the under surface and spines are generally pale yellow or white. Devonshire, Cornwall, Anglesea, and the north-east coast, all round Scotland and the south of Ireland are its commonest localities; but as a rule it is more frequently found below the shore in deepish water. The disc is prettily ornamented, and the arms look very snakelike, and the name of the genus refers to these gifts, and is Ophioglypha.

SEA-URCHINS.-Every now and then a small round, globe-shaped thing, covered with prickles, is found left by the retiring tide on the sand, or amongst weed, and sometimes in a hollow of the rock, into which it fits most curiously. The prickles or spines move 
when touched; they are placed on a hard, armourplated body, and there are no rays or arms to it. They are not nice things for bathers to put their feet upon, and the generally spiny nature of the animal has been compared with that of the Hedgehog. For some reason or other, the Hedgehog is called an urchin; and hence, the creatures now under consideration have been called Sea-urchins.

The naturalist, Edward Forbes, gives one of his inimitable sketches in his book on the "British Star-fishes," in which a couple of boys are playing on the sea-shore. One has a Sea-urchin, and the other is setting a Hedgehog at it, and this unaccustomed visitor to the shore is staring with much intensity at its curious prickly neighbour. But no correct comparison can be made between the common Sea-urchin of our shores, also called Sea Egg, and even Sca'ad Man's Head, and

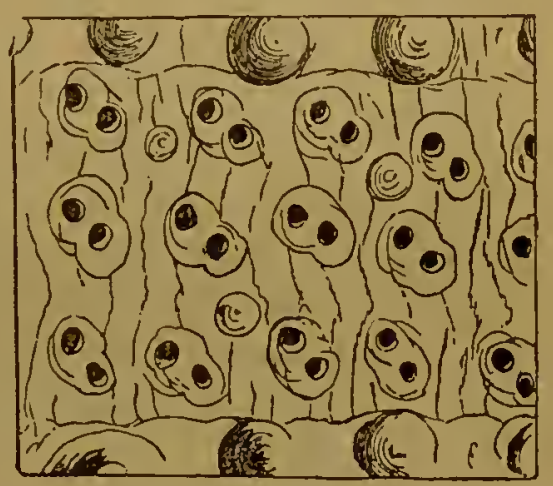

SEA-URCHIN'S SHELL.

(Openings for tentacles.) any other animal. Its mouth is underneath the body; it is legless, and the five parts by which it moves have tentacles, which are on the sides, reaching from the mouth, nearly, up to the opposite or top end. It has eyes at the top, and its vent is there also. Between the five tentacle regions-which remind one of a Star-fish, with its rays brought up and fixed on its back so as to show five grooves with 
tentacles on either side-is a plated test or shell. It is thin, and consists of very many geometricallyshaped pieces of carbonate of lime. Underneath is the inside of the Urchin, and outside the plates are the prickles or spines, placed on joints, and also multitudes of Pedicellarix, which differ in shape, but have the same office as in the Star-fishes. The urchin is usually of a reddish or purple colour, with white spines, and they may be tipped with purple. When the spines are rubbed off, the pretty design of the plates is seen; and if the inside is taken out, a large hole is observed underneath. This is the position of the great jaws and teeth. They bury themselves in sand by moving their prickles, and they hang on by means of the tentacles on the five rows; and if the tide is too strong, they roll about on their spines without coming to much harm. But let one be watched in a nice clear pool, or in an aquarium kept in the cool. It soon begins to protrude, from each of the five bands on its outside, a host of tentacles, many on each side of a groove, and they wriggle, and bend, and expand their tips like suckers. It moves over weed and rock by means of these suckers, assisted by the prickles. These are beautiful objects under the microscope when cut across, and each has a little hollow, like the cup of a cupand-ball toy, on its under side. This fits into a ball with or without a very short stem, situated on a plate of the shell, and a fibrous tissue with muscular fibre in it connects the ball and socket, makes a joint, and moves the prickle here and there.

Ever cleanly Nature provides pincers (pedicellariæ) 
around the prickles, and in and amongst the tentacles; and it is a most extraordinary sight to see a piece of dirt handed from one to another, all down a long row, until it is cast off loose. Inside the urchin is a most complicated jaw, in which teeth move up and down, like so many pile-drivers; but not much is known about their food. It is presumed that they can break into small shell-fish and get their soft parts ; but most urchins, when they are examined, contain mud or sand in their stomach and intestine. Like the Star-fish, they have a ring of nerves around the gullet, and also a water system: the water filters through a "Madreporic" body, and there is a set of bladders along the inside of the shell, through which, water is forced into the tentacles. It is by no means sure that certain beautiful small knobs, situated close to the opening of the shell near the mouth, are not organs of taste. The eyes are as simple as those of the Star-fish.

A Sea-Urchin, called the Purple Egg Urchin, is about two inches in diameter without its spines. These are an inch in length, very slender and tapering, and of a deep shining purple. It is found in the south of Ireland, and ranges to the north and to Arran. The coast of the county of Clare, from the mouth of the Shannon northward, has no harbour, and, except a few bays of pure sand, presents to the eye the most majestic cliffs. Wherever the rocks project into the sea, so as to form ledges accessible at low water, protected in front by higher rocks, and which are never left entirely dry, these ledges are perforated and holed by the Purple Egg Urchin. 
'Thousands of them may be seen in their cavities in the rocks. The hole in which the urchin is found fits it; it is often cup-shaped, and the tips of the spines touch all round, except where there is an opening at the top. The urchin, once in the hole, remains there. Now these perforations are in limestone rocks; and there is no doubt that the urchins make the holes themselves, as snails make corresponding holes in corresponding rocks. Probably, when about a quarter grown, the creature sets to work with its teeth, and drills a hole in the limestone. This it makes larger mechanically, and probably also by getting rid of carbonic acid gas from its gills, and an acid from its stomach; gradually the urchin gets buried, and then the constant movement of the spines or prickles, and the working of the jaws, enlarge the comicile sufficiently. 


\section{CHAPTER X.}

The Common Shore Crab-The Great Edible Crab-The Velvet, Spider, Pea, Hermit, and Hairy Porcelain Crabs-The Spiny Galathea - The Spiny Lobster - The Gebia or Burrowers - Shrimps, Prawns - Case-making Crustacea -The Sandhoppers and Entomostraca-The Barnacles and their transformations-The Insects of the Shore-Beetles and Wingless Insects.

As we walk along the sand close to the water's edge, or grope amongst the wrack on the low rocks just uncovered by the tide, plenty of Crabs of many sizes, but usually of one kind, are to be seen. They are dark green or black-green in colour, often dull red underneath, and the little ones are often mottled with white. Some sham death when they know that they are noticed, quite as well as some insects and spiders do. They draw in their legs and pincers under their body or let them remain stretched out, and do not move or attempt to run away. But if the eye is taken off them, they move slowly in a sly manner and press their hinder part into the sand, dig away with their hind legs, and soon cover themselves, except the very front of the body, from which the eyes and little feelers stick out in the open. Others show fight and raise themselves on their hind legs, extend their pincers, open them, and look very furious, moving oft sideways all the while. If they are taken up by the 
finger and thumb being placed across the back, out of the way of the nippers, they stretch out their legs and bubble out froth from their mouths, and their eyes stick out as in a great rage. They will pinch very hard if they have the chance, and, strange to say, if one of their legs is hurt, or even if a great claw is knocked hard, they cast it off and have done with it

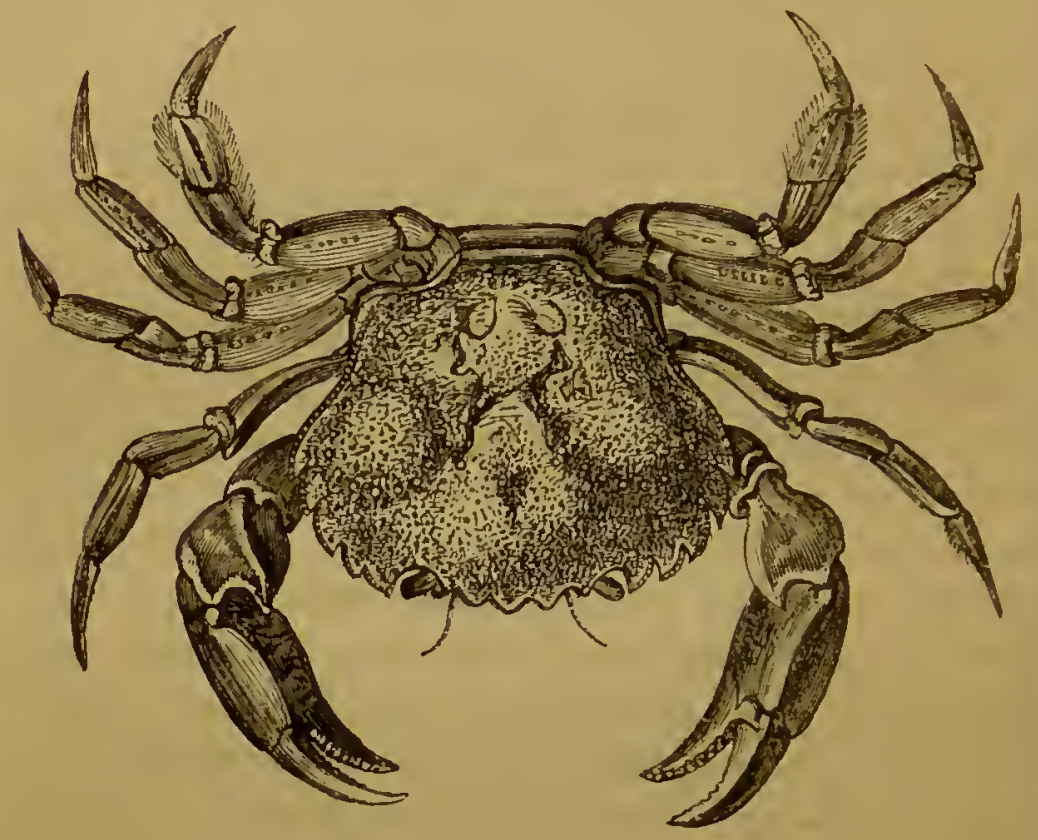

CRAB.

for ever. Moreover, the crab does not seem any the worse, and in time the limb grows again. This is the true Shore Crab. It lives often enough out of sight in the shallow water, and can be caught with any garbage tied to a string, but its natural place is within tide-marks and even beyond. They hide under stones when high and dry, bury themselves in the wet sand 
and wait for the tide again. Indeed, some of them get into places where there is wet sand only and where the sea only comes in at high spring tides, so little moisture do they require. It is very curious to watch them on a wet strip of sand if a dead fish is put down. They come from all sides, making stealthy side-long darts, and run very quickly for a short space. 'Then they make a rush and seize the fish, trying to drag it nearer the water. If disturbed they will often show fight, and if too many come together, they will fight amongst themselves. Thousands of these may be seen when they are about a third of an inch across the back in size, in the shallow salt-water ditches of the Essex coast especially, and they live a very troubled life. The weakest are eaten by the stronger, and, as the live ones scuttle over the sea anemones, they get taken in and digested, although as they grow larger they crawl over these sticky things, and even plunge into their stomachs, to reappear shortly afterwards. When they are hidden up in the sand they watch for shrimps and small fry, dashing out and seizing the unfortunate prey with their strong claws. Roaming about, they are certainly on the look-out for anything to eat, and Professor Bell states that one which took a fancy to a mussel, as it was sticking on a rock, passed its claws within the shell to get the nice morsel and was caught in a trap, the bivalve shell closing on it. They eat in a very sedate manner, holding the food by one claw, picking it with the other, and carrying the morsel to the mouth, down which it is stuffed, and they clear their victims out thoroughly. On the other hand, they may get eaten themselves, if 
they go into deep water, for the Cuttle-fish and the Octopus-like crab, and stick their beaks into their backs and suck the pleasant-tasting flesh.

They are eaten by the poorer classes of the great towns and sea-coast, and, as is known to everybody, they change their colour after boiling. But they are not the best crabs to eat; these will be noticed presently in a brief manner, for they are not properly animals which frequent the shore. The Shore Crab, our dark green kind, is well worth looking at a little closely, for it has some points in its construction which are very remarkable, many being common to all the crab tribe. 'The first thing that strikes any one on looking at a crab, and this one in particular, is that the eyes project from out of a hole on each side of the broad front of the body, that they are on short stalks which are movable, and that they look upwards. The next matter of observation is the hard shell which covers the body on the top, and which is jointed underneath and on the limbs. It is a protective armour of the first quality, and its hardness enables the muscles inside the two large pincers, to bring their fingers together and to pinch and hold. It is made up of carbonate and phosphate of lime and much substance which is not of a mineral nature, but organic, that is to say, of matter which has been formed out of other things by the agency of life. But it is not of one substance throughout, for in a living crab there is an excessively delicate skin outside, which can be made out with a magnifying glass; this does not contain mineral matter. Next and underneath, is a layer of colouring stuff, green on the body in the case of shore 
crabs, and red in places below, and it is the action of heat and hot water on this colouring substance which makes it turn red in almost all animals of the crustacean class, that is to say, which have a more or less hard outside armour like the crab. The colouring matter is contained in cells, which are arranged side by side. Inside this is the thickest layer, and which contains the hard mineral substance. The carbonate of lime is not arranged in it without order, for it is placed in layers from below, one over the other, and there are excessively slender tubes crossing the layers from below upwards on to the surface. There is a time, as will be noticed more fully presently, in the life of a crab, when the shell is soft or membranous, and it becomes evident on examination, that the grains of carbonate of lime are deposited on and amongst a soft animal tissue, after the fashion of the coral and shell of shell-fish, like the mussel. If a thin slice of a crab's shell is made right through it, and it is then rubbed down so as to be made sufficiently thin to be examined under the microscope, the edges of the pile of layers are seen like so many curved lines one over the other. Then crossing them are the crowd of minute tubes, and between the tubes is the calcareous matter, in some places softish and in others very hard indeed, and especially at the ends of the claws, where it is as tough as that of a tooth. Underneath this shelly coat is a thin layer of fibrous tissue, like the tough membrane which is seen in a hen's egg beneath the hard shell. It is permanent, that is to say, it remains on the crab, growing with it in size, whilst all the rest of the shell may be cast off at 
certain periods, the animal then having a soft feel, for the fingers then touch this tough membrane. It forms the foundation of the films of organic matter which secrete, in and amongst their meshes, the carbonate of lime of the shell. It is curious that at certain periods of their growth, the crabs 'and most of the crustaceous animals, like the lobster, prawns, shrimps, \&c., should wriggle out of their hard shells and become soft flabby things for a while, until a new one grows. They suffer much persecution when they have lost their skins, for their natural enemies are aware of the fact and prey upon them. Moreover, the lady crabs are not particularly amiable to the males when they are in full vigour and armour-plated. They are then, just as likely to pinch one of the legs of their swain off and to eat it and him; but they become the softer sex after their strange moult and are not then insensible to the persuasive advances of a very persevering, pertinacious and hard-skinned admirer. The egg-laying, however, is done when the skin is hard again, and the crab makes a hole in the sand and helps the eggs, with its hind legs, into their snug little retreat. Before the casting-off of the old hard shell can be performed, the animal inside must be in a condition to get out, and from the swollen state of the end of the pincers, for instance, and the narrow nature of the part where they are jointed to the body, it is clear that if the muscles inside are capable of filling the shell they cannot be withdrawn; but before the casting-off is commenced, the crab gets thin, loses weight, and its muscles become small. This is a fact well known to lobster-eaters, who, be- 
fore they become experienced, often buy the lobster with the largest claws and find hardly anything eatable inside. At last the crab is so watery and $\operatorname{limp}$ that the shell breaks across between the hind pair of legs and the soft animal backs out. Sir J. Dalzell writes: "I had preserved a middle-sized specimen of the Shore Crab for several months, and which had become very tame and familiar. The heat of a summer's day induced me to put it outside the window of miy study in a capacious vessel of sea-water, where it remained during the night. Next morning, when thinking little of the matter, a crab lying on its back in the tank struck my view, and beside it stood one of larger dimensions, its very image. I hastily concluded that a stranger had been introduced, but no, exuviation had taken place during the night. The latter was the animal clothed in its new garb, and close behind it lay its former self, now an empty shell." The old shell, writes Professor Rymer Jones, is always found apparently quite entire-all the accessories and minutest parts in their places,-bristles, feelers, eyes, all exactly resemble the living and emancipated crab. It is very strange that an animal should shed a skin from its eyes, but this is not restricted to the crabs. Crabs' eyes look staringly at one and move on their stalks, and they are useful and good, for the creature detects the mischief in our intentions and can see sharply when there is anything good to eat on the sands. They are covered with a thin transparent skin, and underneath it a number of small sixsided pieces placed side by side may be seen. Each of these is part of an eye, and there are many in 
the body we consider to be the eye. Beneath each of these hexangular, or six-sided pieces or facets, as they are called, is a glassy-looking body, conical in shape, and beneath this a gummy substance which is in contact with the nerve of sight. Light comes through each of these little eyes in the compound whole, and is kept within its proper direction by dark matter. Here is an eye on the same plan of that of the higher animals, and more complicated than, but still with a close resemblance to, the structure of those of inferior creatures. It is made on the most approved principles according to human knowledge, and serves on land and under water. The feelers which may be seen on the front part of the broad body of the crab, are not only sensitive to touch, but where they join the body, or thereabouts, is the organ of hearing. Moreover, as crabs can discover things pleasant to their taste, when they are out of sight, they must have the sense of smell; so all those special senses which require a well-developed nervous system are to be found. When the shell is shed, something like a skin with hard things on it comes out of the stomach, and if a crab be examined uncooked, round hard knobs of carbonate of lime and skin will be found in its stomach attached to the inner coat and near where the intestine comes forth from the bag-like organ. Crabs, lobsters, and many other crustaceans have their teeth in their stomachs; they are large, movable, and act as crushers on their food. The outside masticating organs of the crab can be seen in motion during life, working from side to side ; they snip, cut, and smash a little, but the real work is done within 
the body, by the stomach teeth. The crabs respire sea-water which contains air, and it gets within the body through a crack on each side near the place where the large nippers join on to the body. The lungs or gills, or branchiæe, as they are properly or scientifically called, are on either side of the body under the lower hard shell, and they are soft and somewhat spongy to the touch. Finally the muscles of the crab, so nice to the taste when boiled, are complicated with minute cross stripes, and are provided with a circulation which has vessels, and they act by means cf nerves.

Naturalists consider that the crab's head and body are united, and the tail is turned in underneath: they have ten limbs. Now, it is a curious fact that: the crab thus formed when it is seen by most of us, is not so when young. Like many insects, it undergoes changes of shape and construction before it attains its full growth. This was discovered by an English naturalist, Mr. Vaughan Thomson ; and Mr. Spence Bate, F.R.S., of Plymouth, corroborated and added to the knowledge of the subject. When the young crab escapes from the egg, it is covered loosely by a transparent skin which fits over all the parts of it, so that the creature is in a kind of swaddling suit. It swims about for a few hours with this strange garment on, and then works about and casts off the skin covering up the head and long legs; then, in a short time, the rest is got rid of, and a creature with a long tail, a spike on its back, a long nose-like piece in front, and two prodigious long legs, swims forth. It is not like a crab. A shell, which 
fits very loosely, covers the sides of the body, and there is a great eye on either side.

It gambols about with the aid of the long tail and legs, and the feelers, pincers, jaws, and small legs sradually grow. Then the immature crab begins to change its skin, and does so over and over again, as it gets too tight for the growing animal within. It moults about once a week, and at the end of a month is bigger, but has much the same general appearance. Nevertheless, accurate examination shows that some fresh limb or organ is added at each moult, and that some infantile feature is lost. For instance, after many moults the great spine on the back is seen no more, and the hind legs get bigger, and the eyes and hearing organs are more perfected. Then, as time rolls on, the long tail shortens and its end becomes a blunt point. Moult after moult occurs, and the tail turns under, the great claws become perfect, and the adult crab, still small, appears, and is able to come on shore.

The crab which is caught in pots and whose great size and nice taste, when cooked, commend it to the lovers of good things, is of doubtful digestibility, and a different kind to the shore crab. It is called the Great Crab, and inhabits the whole of our coasts, "preferring," writes Professor Bell, "those parts which are rocky"; and its usual retreats are amongst the holes in the rocks, where it generally retires when not engaged in seeking its food. It is often seen in such situations, even when the tide has retreated sufficiently to render the rocks accessible, as, for instance, among those on the shore at Hastings, 
where the Professor has often seen them in the pools and caverns left by the receding tide. These are, however, always small individuals, and are rarely more than three inches in breadth. The larger ones remain farther out at sea, amongst the rocks in deep) water. Their food consists of animal matter, such as dead fish and other unsavoury things.

They are large, broad-bodied crabs with huge claws, and are of a reddish-brown on the back; the legs are more red, and the tips of the claws are black. They are nearly white underneath. The under part is hairy, and so are the small feet on the small hind legs. It is not so pugnacious as the shore crab, and it is evident that its sense of smell and taste enable it to discover putrid flesh, for it is often taken in lobster-pots baited with such nastiness.

The fishery for these crabs is carried on vigorously, and enormous numbers are taken yearly. They are taken in crab-pots, a sort of wicker trap made of the twigs of the golden willow. They are formed on the principle of the common mousetrap, but with the entrance at the top, and are baited with the meat on a skewer. The pots are sunk by stones, and the crabs get in and cannot get out.

These Great Crabs cast their skins, and undergo the same strange changes as the shore crabs.

There is a rare hairy little crab with one pincer larger than the other, and it is without any spines on the edge of the hole for the eye or orbit. It is brownish-red, with yellow spots, or colours. The front legs are of the same tint, and the fingers are light brown. The movable finger or claw is bent, and 
the other is strongly toothed. The legs have numerous hairs on them, and the whole body i.s downy. They are found on the western coast of England, and in the south, and on the coasts of Ireland. Usually found in deep water, they are taken sometimes under stones at low tide.

These crabs crawl on the floor of the sea and on the shore, but there are some others which have also the power of swimming well. They have the last pair of feet expanded into a broad fin shape, something like that of a violin. They are great scavengers, and get rid of putrid flesh very rapidiy'. Hence they are called by different names. The fishermen term them Swimming or Flying Crabs, or Fiddlers; and some people call them Cleanser Crabs.

The Velvet Crab is one of these, and most of its shell is covered with a dense, short, hairy pile, and so are the legs. Its colours fade after death, but during life they are of many tints, of reddish-brown and bright blue. It may be seen on the shore, now and then, with the shore crab, and it is the most fierce and pugnacious. It runs with great agility, and slips and raises its claws and shows fight when closely pursued. Moreover, it seizes an enemy suddenly, and holds on bravely. When in the water and swimming, it attacks its prey, and pinches severely if handled.

Another, which is usually called the Cleanser, has a very broad and oval-shaped paddle, and is a pale reddish brown in colour. It is often caught at Hastings in the shrimpers' nets. 
A very different kind of crab is now and then found under stones, or in rock-pools at very low tide, at the mouths of many rivers, and in such places as Hastings, but its commonest locality is in rather deep water. It is called the Long-legged Spider Crab, and it has a triangular body with a sort of projection in front bearing the eyes and beak-looking part. The legs are very long and slender, and so are the pincers, and the whole is hairy. It is a very spiderylooking thing, but it is lazy and cares not to move rapidly. It is timid and delicate, for it dies soon after being removed from the water. So quiet must these crabs be, that small sea-weeds fix and grow on them.

The Pea Crabs are very small round-bodied things with small pincers and legs; and they are interesting, because they commonly are found on the shore, after a storm has cast up some mussel and cockle shells. 'They are soft-budied, and the males and females differ much in colour, the females being the commonest. Some are not more than half an inch in length, and one was found in a cockle, which was alive, and it only measured three lines wher its legs were stretched out. It filled up a good part of the small cockle-shell, and its legs reached from one side to the other.

The crab grows and leaves one host for another, and will stray into oysters sometimes. These small crabs undergo a transformation, and there appear to be two horns to the body, a beak, and a great end to the long tail, in the immature young. Their eyes are red, and the body is of a reddish-green colour, and they sham death in a most amusing manner. 
The Hermit or Soldier Crabs come next, and are remarkable for two things which relate to each other. Their body is covered with a soft membrane, and their hind part is large, long, soft, except some small spots on the upper part, and the tail is hard and has three joints, the second having growths on either side. They live in shells like the periwinkle and whelk, and only come out occasionally to change their home. The shell of the dead shell-fish acts instead of the usual hard covering of crabs, the long tail is required to hold on with, and the growths clasp the centre part of the shell.

The common Hermit Crab has one pincer much larger than the other, and the two pair of hind legs are small. It is red in colour, passing into yellow, the tail part being brown. It is a very numerous kind, and it inhabits, in the course of its growth, every common twisted shell on the coast. In its adult state it is large, and then it seeks the great whelk. When it becomes too large for its habitation, it comes out and seeks another; and thus it is, that often a large shell contains a small Hermit. Professor Bell states: "It is a question of some interest whether the Hermit Crab always chooses for its habitation a shell already empty, or whether it actually kills and devours the inhabitant of one that suits its size, and then takes possession of its violated home. The latter I believe to be true in many, if not in most, cases-certainly, however, not in all, as we often find the Hermit occupying an old and long-abandoned shell; but so much more generally is it found in fresh shells, that it can scarcely be doubted, even on this ground alone, 
that it often obtains its habitation by violence. The fishermen on the coast are fully persuaded of this, and an intelligent person of this class at Bognor assured me that the fact has often been observed by himself and others. He stated that the crab seizes the whelk behind the head, and then kills or disables it, then eats it, and finally creeps into and appropriates the vacant shell. It holds on with great force and tenacity by means of the terminal appendages, and if taken hold of when rumning about, which it does with great rapidity, with its usurped shell attached to it, draws itself in with a sudden rush, and then resists every attempt to pull it out, closing the aperture with its short legs and pincers, which are hard, and thus protects its soft body."

Usually the Hermit Crabs are peaceful, but hungry; they drag their shells along, seeking food, and tumble and roll over the rocks in a very amusing manner. They rake up the sand with their shells, and pick and eat every worm or piece of flesh that comes in their way. Often they will drag their house along, amongst a number of vacant shells, which have been cast up by the tide, and look at them with speculative eyes, as if they thought one of them would suit better than their home. It often happens that a Hermit makes up his mind for a change, and lets go his hold on his shell within, and comes out into the air; but he pops his tail into the fresh shell, and is snugly housed in a second. He has to make haste, for he is a nice tender morsel for many a watcher. Sometimes a small Hermit gets into a shell which he believes will suit him in a short time, being a little too big at 
present, and then it happens that a larger one pulls him out and takes possession. It will be noticed that one pincer is always much larger than the other, and the reason is obvious, for if both were of equal size, the crab could not lie safely within its home, a large claw acting as a cover to the opening. There would not be room for this closing in, were the claws equal in size. In their combats a limb is often injured, and it is then cast off between the injury and the body; the blood ceases to flow from the exposed surface, and the next moult gives a new limb. It has been noticed in the chapter on Sea Anemones, that one of the prettiest Sea Anemones fixes itself to the shell inhabited by a Hermit Crab.

There is a crab which hides under stones at low water all round the coast of England, Scotland, and Ireland, and which is about half an inch long in the body. This is reddish-brown above and yellowish beneath, and it has a great pair of fore-legs, with huge pincers. These legs are nearly three times the length of the body, and are flat and hairy. As if to compensate for the very large front legs, the last pair are very minute, and much smaller than the others near them. Not much is known about this Hairy Porcelain Crab, as it is called, but it is fierce, and if it be saught by its claws, it has the power of throwing them off instantly to facilitate its escape. Its nearest relation is the Minute Porcelain Crab, a tiny thing with a body the fifth of an inch long, but with long fore-legs and big claws. It has two very long feelers stretching out from the front of the body, and marks something like a pea on its back. It is pale red in 
colour, with splashes of brown, and it is very numerous at very low water, loving the neighbourhood of oysters.

The next kind of crustacean to be noticed is found on the shores of Cornwall, Devon, Dorset, and Sussex, and of Ireland, and is more like a lobster than a crab, for it has a long, wide tail, with a fin at the end, besides long front pincers. It gets under stones at low tide, and is of a greenish-brown colour. It is small, being not more than three inches in length, and the last pair of body-legs are very tiny, and the feelers are not very long. This is the Scaly Galathea, and its frequent companion is the Spiny Galathea, which has long feelers bent back over the body, spines on the limbs, small hind legs. It is of a reddish colour, and has blue cross-lines. It is four inches in length. "It is a common kind," wrote Mr. Couch, the naturalist, "throughout the whole of the south coast of Cornwall, and I have lound it on our northern shores. It frequents pools where there are loose stones and sand between tide-marks. It is, generally speaking, very slow in its motions, although it will frequently move with very great activity, especially when alarmed. From the great length of its front pair of legs, its motions are always retrograde. In walking its pace is tardy, but in swimming it darts from spot to spot with the rapidity of an arrow. It is never seen on any exposed part of the pool, but always seeks the shelter of stones, or some hole in the rock, so that it can retire on the least alarm. It is very remarkable to witness the accuracy with which they will dart backward, for several feet, into a hole very little larger than 
themselves. This I have often seen them do, and with precision."

There is an extraordinary creature with a very long tail, short body, and small clawed legs, which has one of its fore claws as big as its body, and hugely disproportionate. It has small eyes, small feelers, and is of a bright red colour when living. It lives buried up to its neck in sand or mud on the Devon coast, and can hide itself completely in its burrows. The skin is half membranous. It is called Callianassa. Another of these burrowing crustaceans, called the Gebia, frequents the mud and sand of Plymouth Harbour. It has not the great claw of the last, and it is said to burrow for a hundred feet or more! These diggers and burrowers kill and eat, protected by their sandy or muddy homes, but they are not able to move or crawl well, when they are turned out.

The common Shrimp is the most abundant of all the shore crustacea; but it is not found on every sandy shore, its place being taken, in some, by a small kind of prawn, which is still called shrimp. The true shrimp is of a grayish-brown colour, dotted all over with dark brown, and it does not become red by boiling. The other, or the small prawn, which will be noticed presently, does turn red after boiling.

Shrimps of the shore are caught by means of nets, which are pushed forwards by the shrimpers, who wade nearly to their middle, raising the net at intervals and letting out the shrimps, which are secured in a bag. They are found sometimes in brackish water during the breeding season, when they carry a heap of dark eggs underneath ; but their usual 
position is in rock or sand pools, and at the edge of the tide. 'They lie close to the sand, and resemble it so greatly in colour, that they can hardly be distinguished; and in order to add to the difficulty of observing them, they cast up sand all around them as they move off by swimming. They have a flat

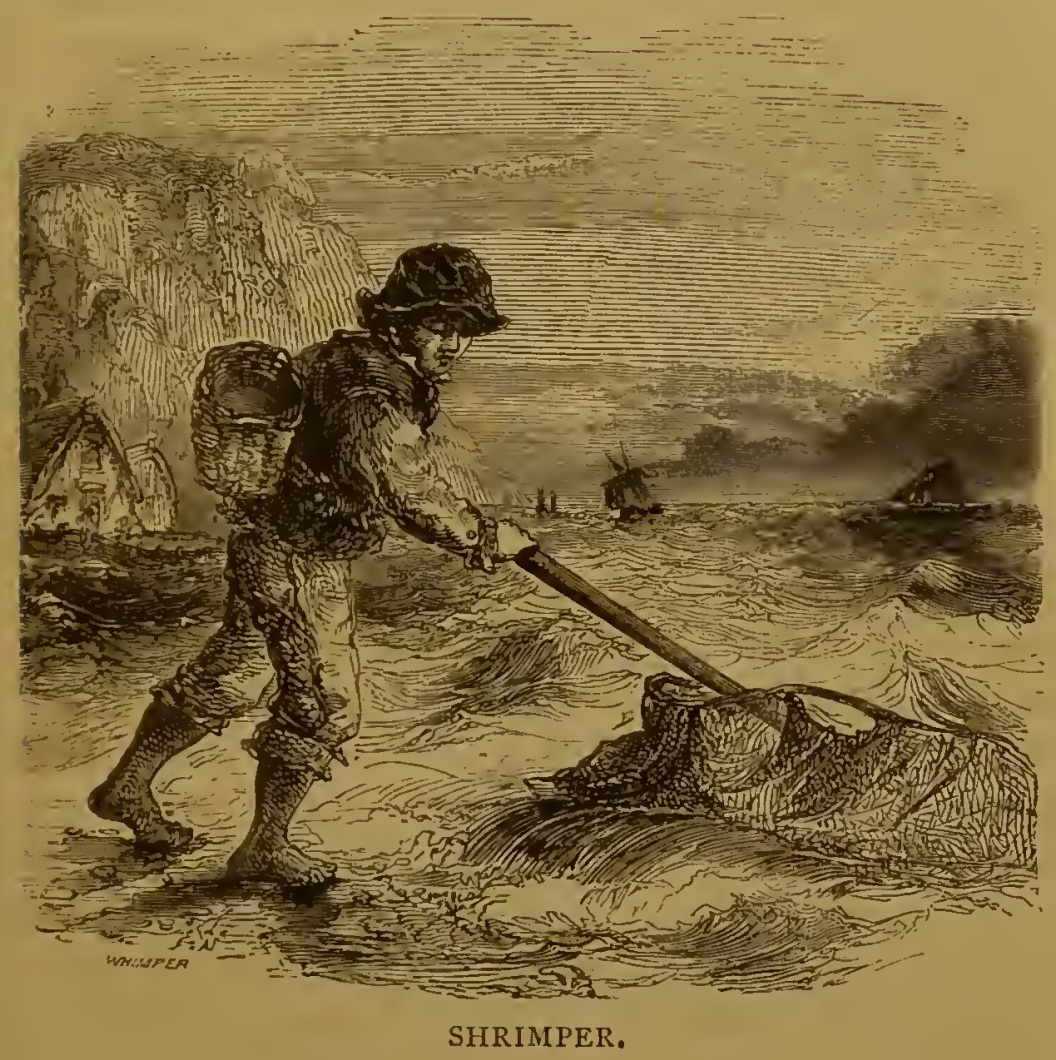

body, especially in front. The eyes are conspicuous, the feelers are long, and the fore-legs are larger than the others and have a curved movable claw, which is turned in to meet a small spherical knob. The other legs are hair-like in size, and one of them 
THE SEA-SHORE,

has two claws. This shrimp is about two and a half inches in length.

When kept in an aquarium, they may be noticed pulling at the sea-weed, and slipping it, or anything they can pull off the rock, into their mouth. They move much forwards by paddling, and rise to the surface; but they do not move much in mid-water. A pretty shrimp, whose colour is a beautiful clear green, is sometimes found in profusion in the rockpools of the south-west coast, and also in Ireland.

The Prawn, so frequently seen large, boiled, and red in shops, when full grown can hardly be called a shore animal; but the young of many kinds of prawns frequent, as has just been stated, the sands of some parts of the coast. They are caught with nets out at sea, when they are required for the London market, and they are usually boiled on board. Probably the young come to the shore, and leave it as they grow older. The length of a large prawn is upwards of four inches; but these shrimps are not much more than an inch and a half. They have large round eyes, a strong, sharp, and ragged beak on the top and front of the head. The feelers are twice as long as the animal, and there are long feet on the joints of the tail end below: The tail is made up of plates, which are hairy. The first pair of legs and feet are very slender; the second reach as far front as the end of the beak. The shell is bright transparent gray, spotted, and lined with darker purplish gray. It is half-solid, and contains but little carbonate of lime. Very beautiful objects are they when small, in aquaria. 
It was noticed in describing the peculiarities of the common crab, that it underwent changes in shape during its growth from the egg to the full-grown creature. These changes are called metamorphoses, and they must be briefly noticed in relation to the Lobster and Prawn. It was supposed years ago that the young lobster started from its egg like the parent, because the fresh-water cray-fish does so. But it was noticed that no one ever saw a young lobster less than three inches long. Mir. Spence Bate hatched lobsters from the egg, and saw their first shape. The minute thing has a short beak on the head, low large eyes, no pincers, and seven pairs of legs, which are furnished with an oar-like branch on the third joint. There are only six joints to the tail end, and the tail itself has a spine. This is not like a lobster. 'Then the next stage shows a growth of pincers on a small scale, and a pointed head, and there are no feet under the tail end. After a while the peculiar claws, \&c., of the full-grown animal are added.

The prawns undergo three changes before they attain their perfect shape. The first shape is with three pairs of legs instead of two, an egg-shaped body without tail or eyes, and there are no pincers. Then the tail end grows, and has two joints at the end with long hairs. The body is round, and another pair of delicate hairy swimming legs without claws exist. 'The eyes appear large, the feelers are used to swim with, and then the mouth is added, and the joints of the tail end. The last shape has the seeing organs given to it, the pincers appear, and a resemblance is noticed to the prawn. Then the next change produces the prawn. 
There is one kind of those crustacca, with unstalked eyes and horny legs on the rings of the belly, which does not pursue the usual hopping and swimming life of the greater part of those which are found on our shores. It is a small creature with enormous feelers, which are as long as the body, and, oddly enough, may be used for the purposes of walking. This Longhorned Corophium makes burrows for itself in the sand; they collect in thousands as the tide rises, and they hunt perseveringly for their prey. It has been noticed that many worms, some of great beauty, live in or on the sand, some in holes, and others in tubes of their own making; and they lie pretty secure if the sand is simply acted on by the ripples. But the Corophizm uses its long feelers to stir up the sand with, and by so doing it lays bare a worm. The prey is darted at instantly, and a pack of them will tug and bite, and finally devour the worm, which may be very many times larger than many of them put together. They attack stranded fish, and the fishermen give them a bad character, and say that they bite through the peculiar natural thread-like cables of the mussels, so that they fall into the mud to be eaten.

Some of the same group protect themselves by forming a case; and Mr. Spence Bate noticed the method of forming the shelter. One of the creatures bent a piece _of green ulva upon itself, and cemented it into a tube-like case in which it lived, putting out its head and feelers only. Upon being disturbed at one extremity, it would quickly turn within its abode and protrude its head at the other. Pursuing this study, Mr. Bate found that a 
large number of these particular crustaceans make temporary residences for themselves, and many dwell in abodes which they have made by excavating channels in clay, mud, or even wood.

The same naturalist, so fortunately placed at Plymouth, secured specimens of a crustacean belonging to tlie Corophium group just mentioned, but differing in the shape and equality of the feelers. "They varied in their ages," wrote Mr. Spence Bate, "from the young to the well-advanced adult, all of which in the course of a short time fabricated for themselves nests formed of foreign materials and partly of a kind of silk secreted for the purpose. During their construction a small area around each lair was swept clean, as if the animal had preserved all the disposable particles fit for the erection of its residence. If we take one of these nests and place it under a microscope, we find that it consists, independently of the collected material, of a quantity of fine threads, closely woven and knit together, crossing each other in the utmost confusion; and here and there are seen loops formed by a single thread being doubled and spirally twisted upon itself."

The common Sand Hopper, thousands of which may be disturbed by turning up the dry sea-weed high and dry, or the larger hanging weed, belongs to this group of crustacea. They are all called amphipods. The crabs and lobsters are termed, from having ten legs or feet, decapods; and the hoppers and their allies have legs or feet to the head, chest, and tail end,-legs all round, as it were, and hence their name. These hoppers are sometimes 
called Sea Fleas, from their manner of jumping, for they put their tails under their heads and strike back, jumping sideways in a wonderful manner. They swim quickly, and much on the side. They nibble and eat everything, and bury themselves in the sand if disturbed. The creature has a good head, with eyes fixed on without stalks, and has feelers on it, one being the longest. Then there are seven joints or rings to the body, and seven more to the abclomen, and all carry limbs which assist in movement, and some of them have an arrangement for breathing.

Numerous very small creatures, with a kind of pair of shields enveloping the body, and under which the limbs appear, the head and tail being at either end, live in the pools and salt ditches. These Entomostraca are pretty microscopic objects.

Barnacles or Acorn-shells are seen, in abundancc, on almost every piece of timber and rock fixed on the shore, and on the shells of many shell-fish such as the mussel. They are roughly comparable, as regards their shape, io half an acorn, the top being uppermost; and if they are looked at carefully, they will be noticel to have a shell, with triangular markings on it at the sides, which slope to the top, where there is a complicated kind of trap-door. 'They are white in colour, often have weed growing on them, for they are fixtures, and appear mostly to be shiit up. By cutting away the wood on which many are found, so as to get underneath the barnacle, a flat piece of ragged shell is found there, jointed on to the silies. The whole shell is like a raiseci pie with 
sloping sides and a lid. They appear to be most uninteresting things, without movement and beauty. Nevertheless, they are amongst the most extraordinary of nature's marvels, and naturalists of the first class have shown that they are related to the crustacean order of animals, to which crabs, sand-hoppers, and water-fleas belong. If a shell covered with them is taken home and placed in clear sea-water, the trapdoor on the top opens, and some little slender feelerlike things, with long hairs on them, come out and begin to lash the water. They are bent slightly, and they move in the direction of their bend and back again. It is a regular and constant movement, and it produces a current in the water; and every now and then some little swimming thing will be observed to get within the range of it, and to be wafted down into the shell. After working away for a time, these hairy lashers suddenly disappear and the trap-door shuts up.

If a large Barnacle is obtained and its shell is broken into-and it is very tough —an animal will be found inside, to which the moving hairy things belong, and if it be dissected, it will be found to be a very complicated thing, which eats, digests, breathes, and manufactures its shell of carbonate of lime out of its food.

Really the animal is stuck fast by its head in the shell, which adheres to the wood or stone, and its legs are the feelers, so that, to use Professor Huxley's expression, "it kicks its food into its mouth." It has a mouth in the shape of a tube or proboscis, and it is surrounded by the usual feelers and movable things 
which are noticed there in all crabs and crustacea generally. As in those very different-looking things, these outside growths are altered to meet the requirements of the animal, the work of profound wisdom acting on a plan by law. There is a swollen lip and little palps are soldered to it, and the jaws serve as a lower lip, and the opening from the mouth to the gullet has strong teeth at hand, which crush and press anything downwards into the hole leading to the stomach, after it has been guided to them by particular spiny structures. The food is brought within range of these by the current produced by the legs, and they are numerous, jointed, spined, and hairy; and the rush of water passing into the body helps to aërate its blood. A very perfect stomach is given to the Barnacle ; it is curved and bent up, and has glands and branching liver tubes; moreover, it is lined with minute cells which secrete the digesting fluid, and turn the minute prey into a liquid that can be circulated and turned into shell, muscle, and nerve. The indigestible parts of the prey become mixed up with the lining and used-up cells of the digestive organ, and the lump is vomited, a new stomach coat being formed afterwards. Muscles are attached to the legs which enable them to move, and others relate to the trapdoor apparatus. The side pieces of the shell are six in number, but they are marked with compartments, six of which are broad below and narrow above, and six broad above and narrow below, just as if twelve triangles were placed side by side, six being turned alternately upside down. The trap-door has four 
pieces so arranged that a slit is left open when required, out of which come the legs.

Now at a certain time of the year eggs collect within the shell, and are cemented together by a substance rather like soft horn, and the mass is cast out at one of the periodical moults of the creature, for it changes its skin like all other crustacea. As soon as an egg is hatched, a little freely swimming thing comes forth. It has a long triangular-shaped body, with projections at the sides and front, and one at the tail end. There is a mouth, like a sucking-tube, nearly in the middle of the body and in the midst of three pairs of swimming limbs, two of which are divided into two parts. It swims with those limbs which are hairy, and after a while becomes quiet and changes its skin. Then, when it comes out of its old coat, it is found to have two feelers on the head in front of the mouth, and a single eye is seen close to their base. It moults several times as it grows, and assumes a new form by entering the second stage of its life-cycle. The united body and head are now oval in shape and flat, there are two eyes, and the first pair of swimming limbs are turned into feelers, each of which is provided with a sucker. Moreover, six pairs of delicate legs make their appearance behind the mouth. Moulting several times, the creature arrives at its next stage. Still freely swimming, it gets the shape of a mussel shell, and the limbs and lower parts are hidden by the back. It has now two large compound eyes, and the solitary eye just noticed is arrested in its growth. The most extraordinary thing is that the opening to 
the mouth is covered up with a skin, and the creature cannot eat or take in anything. It has six pairs of legs, and some glands are formed in the body, which have tubes passing into the feelers to the suckers, and they secrete a cement. This is the last stage of the freely swimming thing, and Mr. Darwin, to whom we owe this wonderful account, says the animal, after swimming about for a while, selects its permanent resting-place. It places its head against the stone, shell, or piece of wood, and sticks on by its suckers on the feelers. The glands produce cement, which flows out and congeals, and the barnacle is fixed. It then turns up its legs and stands on its head, the shell is formed around, and extraordinary internal changes occur. The grand eyes are positively cast off, and the reproductive organs appear, and the mouth is opened. Fixed for the rest of its days, the barnacle grows, casts the skin which lines its shell, not the shell itself, and in time produces eggs which pursue the same wonderful development.

There are a few Insects which live the whole of their lives on and about the shore. Thus Aepus fulvescens, a small beetle of the family Harpalidæ, passes a great portion of its life under the sea. It lives so low down on the beach that it can only be uncovered at spring tides for a few days twice a month, so that it seems highly probable that they have the power of obtaining food whilst covered with water.

Another beetle, Staphylinus tricomis, may be seen on the sand-hills on the Norfolk coast. The males 
keep in the level spaces between the hills just as the tide begins to ebb and they become sufficiently firm to walk over. They are on the look-out for the females, which inhabit holes in the sand, and live a sub-aquatic life.

One genus, Raptor, has its three British species maritime or sub-aquatic, for they are all found in habitations in the soil which is covered with water, or which is below water that stagnates inches deep in marshes, after the tide has flowed and ebbed.

The Aepus just mentioned is a very little hairy thing, and is extremely active. It runs over the weeds and stones, and when a wave comes, hides up under a stone, and is covered for a while with mud and water, from which it escapes. It lives, thanks to the property which its hairy skin has of keeping globules of air adherent to it. These will support the insect, and enable it to respire. It rarely is found longer than $\frac{x}{12}$ th of an inch, and the colour of its body is a reddish-yellow. The jaws are sharply pointed, and there are no wings beneath the covers or elytra, and the feet end in curved hooks.

The Fish Scale insect, Lepisma saccharina, whose delicate, microscopic hairs and scales are employed as objects to test microscopes, has a relative which lives in and about the wet rocks and sea-weed. It is called Machilis maritima, and is common. It is a wingless insect of course, and probably it is one which does not undergo any metamorphosis or change of shape. About half an inch in length, it has a long spindleshaped body, with two very long feelers on the head, and three tails, the centre being the longest. There 
are three short legs on either side. It is of a brown tint, with orange metallic reflections. The feelers are brown, and the points have white rings on them.

Many other insects frequent the plants by the shore and come on to the space between the tides, but their lives are not spent there, as in the above instances. 


\section{CHAPTER XI.}

The Shell-fish :- The Solen, Cockle, Pinna, Telline and their peculiarities-The Limpet, Periwinkle, Purple, Whelk, Earshells, and Chitons-The shell-less kinds.

A PAIR of shells adhering to each other along one edge, the whole rudely resembling a razor-case without the blade, and sometimes five or six inches in length, are often found on the sand, their tenant being dead or absent. Each shell is rather thin, bent to form a long part of a cylinder, and when the two are. together there is a space at both ends. The animal of these razor shells, called the Solen, frequents sandbanks which are only uncovered at low spring tides, and their presence may be detected by marks on the sand. These marks are little hollows, which have been compared to keyholes. They lead down to the animal, which lives in the sand from a depth of a few inches to two feet, in an upright position, and if they be watched, a little jet of water is thrown out, if any movement is made on and about the sand. This peculiarity, arising from the casting out of water from a part of the animal, is fatal, for the fishermen, who use it as bait, watch their opportunity, and, furnished with a barbed iron rod, plunge it into the sand, and usually strike the creature and bring it out. It is 
quick work, for if the blow fails it is of no use repeating it, as the Solen excavates and gets down a foot or more in a few seconds.

Rymer Jones writes that a still more simple mode of obtaining them without injuring the animal, is by putting a litile salt upon their holes. 'The salt, penetrating the perforation in the sand, reaches and irritates the ends of the tubes or syphons of the animal, and it immediately rises in the sand to the surface. By watching the opportunity, the Solen may be seized; but unless the operater be very quick, and quicker than the shell-fish, he will miss his chance, for the wished-for prey goes back into its burrow, and will not come out again for salt or anything else.

"Nothing," writes the same charming author, "is more wonderfully illustrative of the perfection of structure conferred upon these humble creatures,

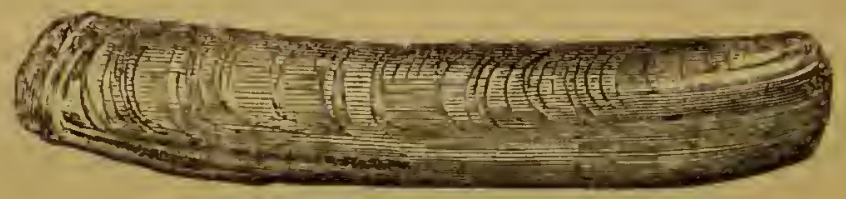

RAZOR-SHELL.

than the machinery whereby they are enabled to burrow beneath the compact, and at the same time loose, material wherein they dwell, a fact that may be readily witnessed; for if the Solen be taken out of its hole and placed upon the sand, it immediately prepares to bury itself by the assistance of its enormous 'foot,' which it at once stretches forth to its full length. This 'foot' may be seen in a dead 
Solen by opening the shells and a peculiar fold of membrane which is inside them. In the midst, there is a long substance which can be separated from the rest, and it is the organ of locomotion or foot. The end of the foot when protruded, before the Solen attempts to bury itself, has a flat shape, ending in a point, and it is by its means that the sand is. penetrated. Driving the end of this singular weapon to a considerable depth with the greatest ease, it bends the end into the shape of a hook, and thus. acquires a sufficient hold and purchase to drag the shell into the vertical or upright position. When this is done, all that remains is to bury itself more deeply, and for this purpose the foot is once more unbent and elongated, and forced downwards to the extent of one half or two-thirds of the length of the shell, and, as the foot retains its peculiar dagger shape, no. resistance is offered by the sand. Now conmences. the most remarkable part of the operation : the foot, all on a sudden, completely changes its shape; without at all diminishing in length, instead of being flat, it becomes at once round or cylindrical, and then suddenly swells out near its extremity into a. great fleshy globe, thus assuming a shape like the clapper of a bell. By means of the fleshy globe, thus imbedded firmly in the sand, a secure hold is. obtained; when, by shortening that portion of the foot which is situated between the globular addition and the shell, the latter is forcibly dragged downwards; and thus, by a repetition of the same process, the creature manages to bury itself with a rapidity that is quite astonishing." 
The manner in which it re-ascends towards the surface is precisely the reverse of the preceding operation. The foot becomes dilated into a bulb, close beneath the inferior end of the shell, and then taking a firm hold of the surrounding sand, the Solen is enabled, by forcibly elongating the organ, to push itself upwards. ${ }^{1}$ The movements of the foot may readily be witnessed, states the author from whom this description is taken, when the razor-shell has been dug up from its hiding place, particularly that whereby it is enabled to bury itself in the sand, for if held up in the fingers, it thrusts out its leg and performs all the necessary evolutions, whilst making fruitless attempts to save itself after its usual plan of escape.

Cockles are dwellers in sandy bays near low water, and often get left by the tide, and some live in the brackish water of the Thames as high as Gravesend. The common kind is eaten, and before boiling it is often made to jump for the amusement of its captors. There is a foot which comes out between the shells, and it is long, bent and round. Placed on the sand, the Cockle, desirous to get back to its element, stretches out its bent foot as far as it can, and then suddenly skips forward or backward, and makes stärtling little jumps. Equally well known are the Mussels, which may be found clinging on to rocks, piles, and stones, usually covered by the sea near lowtide mark; but they do not possess the jumpingpower of the last-mentioned shell-fish, or the diggingpower of the Solen. Nevertheless, they have a remark- 


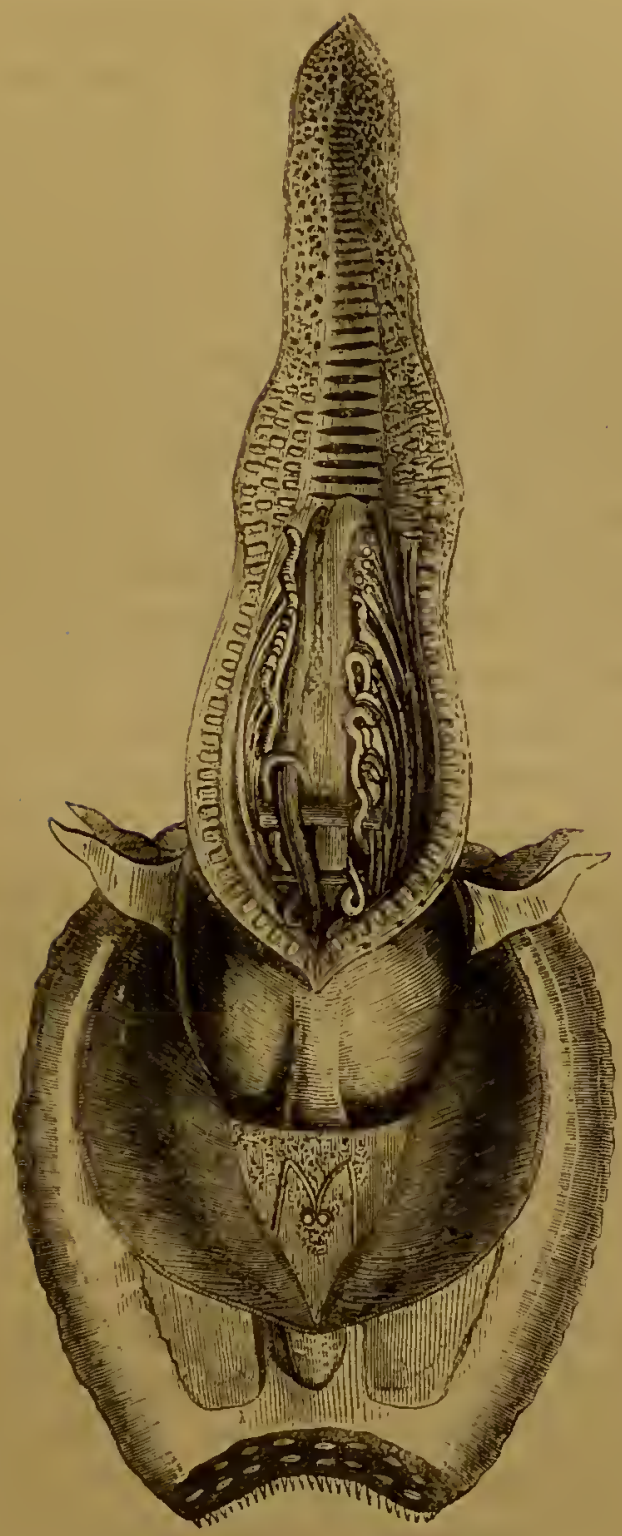

MUSCLES OF COCKLE'S FOOT.

able anchor and cable, or rather a set of anchors and cables. 
When a living Mussel is found attached to anything, a number of delicate threads, which seem to come out of the body through a crevice in the shell, are observed to have rounded and flat ends. These adhere by being inserted in the rough parts of stones and wood. The whole bunch of threads comes from a little rounded part of the body, underneath which is a small foot, with a gland attached to it, and this gland secretes the horny matter of the threads. They may be broken off or torn away, and they will be replaced by the growth of fresh ones. As the mussel is always attached, in its natural position, a foot which would enable it to dig or jump would be of little or no use to it. But it requires holders on, or it would be swept away by the waves; and hence this bunch of thread or byssus is provided. A shell-fish somewhat resembling the mussel, but with long wedgeshaped shells, is sometimes found in the sand and mud of the south of England, and it is called the Fin-shell or Pinna. It is remarkable for the large size of the byssus, and there is a great crowd of threads, by which it attaches itself.

Shells with finely sculptured lines on the outside, are now and then found on the sand close to the extreme low tide, and they do not appear to have much power of moving, being probably inhabited by sedentary creatures. They are the Tellens, so called from telline, the Greek name for a kind of mussel ; and as they bury themselves in the sand out of the reach of most swimming enemies, they have a broad and pointed foot sufficient for the purpose, but there is no thread apparatus. Such shell-fish as Oysters and the Mya 
are not dwellers on the shore, although the first may be seen uncovered now and then in certain places near oyster-layings, and the other is occasionally seen at very low spring-tides. All these shell-fish have two shells, and are called shell-bearers or conchifera. Their natural positions differ, for the Solen is found upright in the sand, the mussel is fixed on its under edge with the back up; and the others are frequently found on their sides, or in the position of the mussel. In all, the shells, or valves as they are termed, are united together inside, by muscles which pull them together, and others enable them to gape; and there is a curious sort of hinge in the shell, which with a ligament, antagonizes the muscles within and tends to open the shell. They all belong to the great group of living things called mollusca, and their shells are produced by the processes of life, and grow in consequence of the animals taking in food which contains carbonate of lime. The shells are formed by a part of the body which lines the inside of the shell, and has on its free edge the gills or breathing organs; moreover, sometimes a very delicate skin passes over the shell, being visible in some kinds to the naked eye. The mantle, as this inside film of soft tissue and its outer prolongation are called, has a great supply of blood-vessels, which carry to the outer film of it the mineral matter which is to be deposited in its delicate meshes. On examining any of the shells of the molluscs just noticed, they will be found to be shining and mother-of-pearl-like in some parts, and dull and filmy in others. In the mother-of-pearl part, the delicate membrane or tissue, 
in and about which the granules and crystals of carbonate of lime are deposited, is much folded and plaited; and hence the colours. On placing these substances in weak acid, the organic part will remain undissolved. The other part of the shell also contains its fundamental structure, and the mineral part is arranged in very different patterns, according to the kind. Dr. Carpenter has shown that most beautiful prisms of many shapes and sizes are found made up of carbonate of lime in shell, and that they are produced by the mantle acting as a skin and depositing the mineral in its cells. The mollusk lives either on vegetable or animal substances, or on both, and of these many sea-weeds contain carbonate or some other salt of lime, whilst the young minute animal things which they swallow usually have shells. Deposited in the mantle in the same manner as the mineral substance is secreted in the substance of the coral, or in the skin of the crab, the carbonate of lime of the mollusk is, therefore, produced by the gift of life, and is not a mechanical matter.

The shells of these creatures are not cast off and renewed as in the crabs, and they grow at their edges, by additions from the mantle.

On opening the shells of the Solen and Mussel, the gills are seen on each side, and they are those parts which are called the "beard" in the oyster. When the animal is closed, the water can get into the shell between the gills, which are sometimes arranged in a tubular form, and they act as filterers, two currents being set up, one inwards and the other outwards. Any food and the impurities of the water 
are collected on the surface of the gills and gradually moved along to the mouth of the creature, down which they go. This mouth has parts near it like lips, and it leads to a stomach and curious intestine, which, in some, goes through the heart. The gills are beautiful objects under the microscope, from their being covered with cells bearing minute cilia, which are in constant motion, in order to produce currents in the water. These shell-fish have a liver and a circulation, as well as a nervous system, but their special senses are at the lowest ebb of development, for it is doubtful whether even light can be distinguished by some.

The other mollusca of the shore which are shellbearing, have one shell only, and the Limpet found by the thousand in some parts, is a very common and well-known example. How its roundly conical shell sticks fast to the rock, and is even sometimes a little imbedded in chalk; is well known, and most young people have given up the task of getting one from off the shore uninjured, as a waste of time and trouble. They are used for bait in fishing when they are taken from the shell, and in some parts of Ireland they have been eaten as food.

On looking at the under part of a Limpet, called in the language of conchologists Patella, from the Latin for a little dish, nothing but a flat piece of flesh is seen, which contracts on being touched, and goes further into the shell, and which often has pieces of chalk, rock, and sea-weed adhering to it. This is the great circular foot by which the Limpet sticks on to the rock, and it is nearly as large as the opening 
in the underneath of the shell. It acts as a sucker; the Limpet squeezing out all the air and water between its foot and the rock or weed, and maintaining its position by the pressure of the air and water, which often amounts to possibly twenty-five and more pounds on its surface. Place the Limpet in a dish of sea-water, and watch awhile, and it will begin to move, a head, furnished with feelers with eyes, where they join the head, coming forth. Then a little care will enable the observer to tilt up the shell and see a circular gill inside. The head has a small mouth, armed with an upper part which is horny, and there is a long ribbon-like thing inside called the tongue, and which has many teeth on it. This long apparatus, or tongue, is for rasping the food, and is attached to the floor of the mouth. Its most important part is that which is horny, and armed with tooth-like or saw-edge-like pieces arranged in sets, and this so-called radula is secreted like a skin by the tissue beneath. The teeth get worn in front and at the tip, and are replaced by a succession from behind. The membrane which secretes these, lies in a sort of trough in a gristly part of the tongue, which strengthens the whole. The Limpet has 160 rows of teeth on its tongue, and each row has $\mathrm{I} 2$ teeth, making $\mathrm{I}, 920$ in all. It rasps sea-weed, corallines, and nullipores, and the food is carried down the gullet to the stomach, and it often rasps the surface on which it rests. Moreover, as it breathes by giving out carbonic acid gas, and letting in the oxygen of the air mechanically suspended in the water, the first-named gas 
corrodes the limestone and chalk rocks on which it is placed.

The Limpets were very numerous in some parts of the north-east coast of England years ago, and it is said that a scarcity was produced, by no less than twelve millions of them being collected every year for bait. Our Limpets never grow very large, but there is one which is found on the western coast of South America, the shell of which is used as a washing-basin.

Next to, and even before the Limpet as a common shore shell is the Periwinkle, but in it the shell has a twist, is more or less spiral, and the opening is not opposite the end, but in front and below, in the proper position of the animal when feeding. The animal of the shell is so well known that it hardly needs description, but it is nécessary to notice that it has a trap-door or operculum, which closes the opening in the shell when the creature wishes for quietude. This is pushed aside as the foot, on which the animal crawls like a snail, is put out, and then a head with a sort of muzzle, and tentacles with eyes close to the head, appear. They may be said to mow the delicate sea-weeds and conferva off the sides of the aquarium, and they browse on the weeds on the shore, between tide-marks. There are two kinds common on our shores; one inhabits the shore between tide-marks, and deeper, and lays eggs; and the other lives where the tide bardly ever comes, and produces young very like itself, which have a hard shell before their birth. They are very snail-like, and in the Hebrides the thrushes think so, 
for they consume them in the winter time. Everybody has picked out a cooked periwinkle with a pin, and enjoyed the animal at some time or other of one's life, so the general appearance is familiar. The first thing to be noticed is the horny trap-door; this is marked with a pattern in lines, as if they were in a flat spiral, and it evidently grows with the size of the creature, fresh substance being added on the edge, remote from the first twist of the pattern. These trap-doors are sometimes calcareous, and shelly in some others of these mollusks which move by protruding a foot which underlies the rest of the body, but the horny kinds are supposed to be somewhat analogous to the broad ends of a byssus, such as that of the mussel, for instance, joined together at the end. The part of the body within the shell which comes out last in a sort of twist, and is brown in colour, is the liver, and the end of the stomach is in it also ; near where it joins the rest of the body there is a large blood-vessel called the aorta, and nearly on the surface is the egg-producing apparatus. Further out are the gills, and underneath the head, within the skin of the neck, is a gullet, a salivary gland, and a curious coiled-up thing which is the tongue. The mouth leads to the gullet, and on its back and lower part is the tongue, which turns up on the right side, and ends in a twist or coil like so much spun rope, often $2 \frac{1}{2}$ inches long. There are 600 rows of teeth on it, and only the front part is in use, and that has about 26 rows. The Periwinkle is essentially a vegetable-feeder, and the lime of its shell is got like that of the other shell-fish already 
noticed. A mollusk having the foot able to be put out of the spiral shell, and to be used as an organ for locomotion, like the Periwinkle, and having the internal organs of digestion, \&c. above it, belongs to the group of Gasteropoda or stomachfooted. One of these with a short spiral shell, having a large opening notched in front, is called the Purple, and it is common enough under seaweed and stones between tide, and affects the neighbourhood of the Periwinkles. It has an operculum, and a remarkable proboscis, which coming out of the mouth can be turned here and there, pushed out, and retracted into the body, and it is drawn in so that its body half encloses the outer and free end. The Purple is not a vegetarian, but lives upon those which are. It is carnivorous, and the constant enemy of the Periwinkle and Limpet. The Purple sidles up to a Periwinkle and puts his foot on its shell, and then out comes the proboscis, which acts as a penetrator. The shell is perforated, and then this curious organ passes in to act as a sucker, and finally the flesh and juice of the winkle get into the stomach of the Purple to add to its shell, muscles, nerves, and organs.

Rymer Jones describes this borer, situate at the tip of the proboscis, as being a formidable instrument, armed with hooked and very sharp spines. It is supported on two gristly or cartilaginous levers, the extremities of which form a pair of lips that can be separated or put together, or made to move upon each other by the mass of muscles wherein they are imbedded, in such manner that the spines covering 
them are alternately depressed and elevated, so that by a repetition of these movements the hardest shells are soon perfcrated, as by the action of a file.

The eggs of the Purple are placed in little urnshaped bladders of a membranous texture. They are yellowish or pinkish, and may be seen placed upright on the surface of rocks or stones, or on the parent shells, they being stuck on to these objects. Each of these little urns contains many young Purples, which: escape when they are mature.

The Whelk is so well known that it is only necessary to remark that it bores into other mollusks like the Purple; and so does the Dog-whelk, which is also found at low-water edge and deeper. The eggcapsules of the Whelk are well-known shore objects, and they occur in roundish masses, each "egg" being rounded in one direction and pointed in the other. Each contains perhaps five or six young, which escape out of a round hole.

The Tops have a top-shaped or pyramidal shell, with mother-of-pearl inside, and the animal has two long feelers. The eyes are at the ends of slender tentacles, and the head and sides of the body are fringed. It has a tongue, and very numerous teeth, and is a vegetable-feeder. One of these, with a pretty zig-zag pattern on the outside, has its shell almost with a flat base, and is common at that place for shrimps called Pegwell Bay, near Ramsgate.

The Ear-shells are really more or less ear-shaped, and have a small flat spire. Their opening is very large, comprising nearly the whole under-surface, and they show a beautiful play of colours on the shell. 
There are a number of holes on the outer rim, and a horse-shoe-shaped scar on the únder part of the shell, where a muscle was attached. These beautiful shells abound on the shores of the Chamnel Islands, where one is called the Ormer. 'The animal of this pretty shell has no trap-door; it has a short muzzle and tentacles. It is said to adhere to rocks with a large foot, like a limpet.

These are the commonest of the mollusks which have shells, and which are found on and about the shores; but there are many others with two valves which, from their living in sand and mud, are only known to naturalists. One with gaping shells, equal in size and triangular, is called Mactra, from a fancied resemblance of the shell to a kneading-trough. It has a wonderful foot, which moves like a finger, and can be employed in leaping. 'They are eaten by Star-fishes and Whelks; and one kind is sufficiently common in Arran to be collected for pigs. The other shell buries itself vertically in sand and mud in brackish water neighbourhoods.

Often on rocks at low water, a curious one-shelled mollusk may be noticed which looks like a long flat Limpet, with the shell arranged in several pieces along the back. There are perhaps eight across-placed plates, or parts of shell, one of which fits over the other. The border is often whole, and may be spiny. This is called the armour shell or Chiton, and the animal has a broad creeping foot like the Limpet. There are no eyes or tentacles, but a proboscis armed with cartilaginous jaws, and a long, linear tongue, with teeth on it. 
All the shelled mollusks, which have been noticed in this chapter, have the gills or branchiæ, or the breathing organs protected by and within the hollow of their shell or shells. Those about to be noticed, which have no shell, and which are popularly termed Sea Slugs, have the gills on the back, or on the sides of the body, and they are called the nude-gilled, or $N u d i$ branchiate Mollusca.

They are to a certain extent shaped like Slugs, and usually are, less or but slightly more, than an inch in length. They are broader in front than behind, are low, and the head is highest. The body is flat beneath, and it moves on that part, whilst the back is rounded and variously ornamented, and furnished with gills of very pretty shapes. The gills are covered with microscopic cilia. Ore, which is called the Sea Lemon or Doris, feeds on sponges and zoophytes, and is to be seen, now and then, close to low-water mark on rocky shores. It has two conical or nail-shaped feelers or tentacles where the head joins the back, and they can be withdrawn into their cases; and it has the gills in the form of a raised circle, like a crown, far back on the body, and they can be drawn in. Like the Gastcropoda it has a tongue, and a very complicated tooth arrangement. Another has the gills in the same shape and position ; but they are branched, and it is a true dweller on the shore; whilst a third has the gills pinnate, like a mimosa-leaf, and there are knobs around them. One which has tentacles which cannot be withdrawn, has also two other projections at the side of the gills, and is called the Many-horned Doris. Some of these 
animals, instead of having the gills in a circle, have them in rows along the sides of the back, and they are feathery-looking, or like pimples. These are found under stones at low water, and are called Tritonia: one kind, which has the gills branched and tree-like, is a very tufty-looking thing, and the head is furnished with very bushy feelers. A set of these slugs has long tentacles on the head, and the body is ornamented by fringes of gills all down the back and sides; and one, called Aolis, is found amongst rocks at low water, where it is very active, constantly moving its tentacles and extending its gills. They feed on zoophytes, but have no objection to eat their weaker fellows. 


\section{CHAPTER XII.}

The Shore-fish :-The Fifteen-spincd Stickleback and its nests

- The Viper-weaver-The Father-Lasher or Lucky Proach

- The Rock Goby or Miller's Thumb-The Two-spotted Goby-The One-spotted Goby and other species-The Suckers :-The Cornish Sucker-Montagu's Sucker-The Connemara Sucker-The Shanny-The Halflieaks-The Sea Adder or Pipe-fish-The Three-bearded RocklingThe Sand Eel or Lesser Launce.

The Fifteen-spined Stickleback, or Sea-adder, is known on all the coasts of the United Kingdom, and has been discovered to be in the habit of forming a nest for the security of its young, and of watching over their safety in it, until they can take care of themselves. This interesting discovery and its careful study we owe to $\mathrm{Mr}$. Couch, and not to a foreign savant, who forgot to write whence he obtained his information.

The fish is not likely to be seen by many people, as its nests are usually in harbours or recesses near the open sea. But sometimes they are found in pools amongst the rocks, and it is not rare to find them between tide-marks, where the moisture of the materials of the nest appears sufficient to save the grains of spawn from suffering injury by exposure. 
The fish is about 6 inches in length, and it is long and very slender at the tail, and the tail fins are very large. The head puts one in mind of that of a small pike, and there is a row of fifteen small spines on the back, and each with a little piece of membrane on it, in front of the fin. The nostrils are midway between the snout and the eyes. The colour varies: in some it is reddish-brown on the back, and this is the colour of the first rays of the dorsal fins and tail. In others it is deep green. The cheeks and sides are often golden yellow, and lighter on the belly. It changes its colour quickly under the influence of terror. It is a very active fish ; and Mr. J. Couch, F.L.S., from whose work these notes are taken, has known it to throw itself over the brim of a vessel where the water was 3 inches below it.

It feeds on crustaceous animals, and, indeed, on any animal substance it is able to swallow. Mr. Couch has known it attack and partially devour an eel of 3 inches in length, which it was, however, finally compelled to reject.

The method of procedure in forming the nest is thus stated by Mr. Couch:- "The fish either find growing, or, certainly in some instances, collect together, some of the softer threads of green or red sea-weeds, and join them with so much of the coralline growing on the rock, as will serve the purpose of affording firmness to the structure. They constitute a mass, 5 or 6 inches long, of a pearlike shape, and about as stout as a man's fist. A thread is employed with much skill and patience in winding 
these materials together, and there is no doubt that its substance is derived from the creature's orvn body. It much resembles silk, and is elastic, and appears to consist of smooth threads glued together." The roe is laid from time to time during the formation of the nest, and is mixed up in its meshes and threads. The male watches over the nest, and is never away from it long, and returns with the tide. $\mathrm{He}$ continues his guard until the young swim, and if the eggs are exposed to sight, he folds part of the vegetation of the nest over them.

The sandy shores of Scotland and the bays of Dublin and Belfast, and indeed the corresponding situations on every part of the English coast, have the Viper Weaver or Sting-fish, burying itself in the loose soil of the bottom of the shallow water, or remaining in the wet sand. Trodden upon by accident, it strikes with force, either upwards or sideways ; and Temnant, one of our great naturalists of the past, states that he has seen it direct its blows with as much judgment as a fighting-cock.

Montagu says, "Whether the supposed venomous quality of the sharp spines is justly founded is difficult to determine; but it appears to be a fact that the wounds inflicted by these weapons usually exhibit symptoms of great inflammation and pain, and which, too, give rise to the vulgar name of Stingfish." This fish is small, and is rarely longer than 5 inches, it has an ugly spine on the gill-cover, and there are others on the fins behind the head.

Another, and very ugly fish, is occasionally left in pools, and is, to a certain extent, a shore animal. It 
is called the Father Lasher or Lucky Proach, and is to be found from Scotland to Cornwall. About 6 or Io inches in length, it has a large, wide, flat head; its eyes are close together on the top; there is a wide mouth, and covering the gills are spiny covers which give a horny or thorny look to the neck. The fins on the back are as spiny as those of a perch, and it is of a dark-green colour, the underneath being white. When it is touched, it distends its gill-covers, sets out its numerous spines, and looks very threatening. They eat small fish and

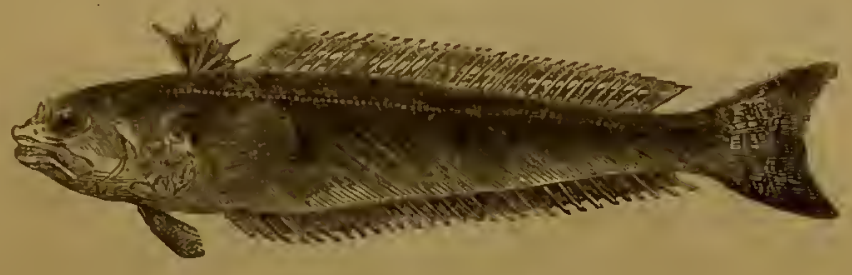

VIPER WEAVER.

crustacea, and are eaten in return, not by our people, but by the Greenlanders, on whose shores they grow to some size. They conceal themselves under a stone or sea-weed and rush out at their prey.

A host of the Goby tribe are shore fish, either in rock-pools or sand-ponds, at all heights above-lowtide mark, and the first to be noticed is the Rock Goby or Miller's Thumb. It is of a mottled-graybrown colour, with black spots on it, and the usual length is about 6 inches. Mr. Couch says that it breeds in the open sea, but that it is constantly found in rock-pools of such elevation that it is only in very high tides or stormy weather that the water of the ocean can flow into them; and into many of them a 
rill of fresh water is constantly dribbling, so that the saltness of the water is lost. This is the farourite resort of the Goby, where it is safe from the attacks of the predacious fish and Cormorants. These pools are clothed with green sea-weeds, on which the Gobies sometimes feed, but they usually attack the small crustaceans which inhabit the spot. It is a lively, sharp-sighted fish, and if discoryered swims off to a place where the colour of the rock or vegetation resembles its own. It rests on the ground, and is

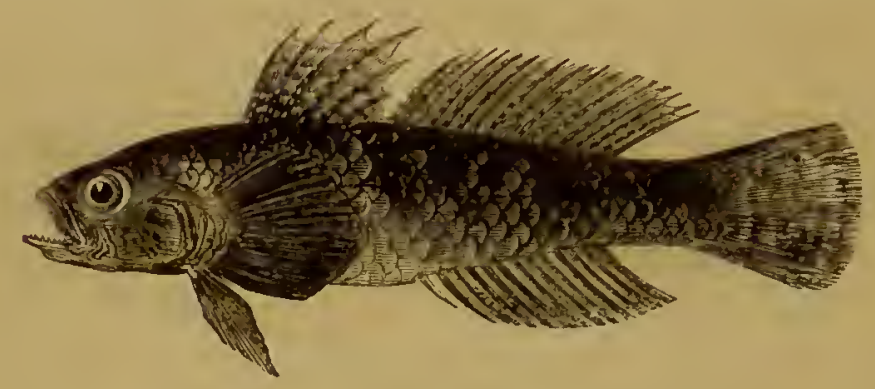

BLACK GOBY.

content to live in either fresh or salt water. There is a curious fin on the lower part (ventral).

A Goby with two dark spots, surrounded with lighter colours, on each side of its body, and with a dark-brown tint, is often seen on the shore coming in with the rising tide, and either rushing after prey, playing, or swimming off with all sorts of twists and turns to get behind a stone or weed if it fancies itself in danger. About 2 inches in length, they are handsome little things, and are a prey to the larger shore fish. There is a One-spotted Goby, a Little Goby, a Tail-spotted Goby, and many others, all lively fish, and much more interesting to the zoologist 
who tries to make out species from very variable things, than to any one else.

The Sucker or Cornish Sucker, so called from its having been first found in that part of England, and for having a portion of the underneath of the body which, divided into two parts, adheres to stones or any hard substance, as if by suction. One of these taken up in the hand trembles, as it were, and then is found to have stuck to the palm or fingers. When in shallow water, or under a stone on the shore in a pool, it will remain inert and quiet for hours, fixed on to something or other; and even after death the

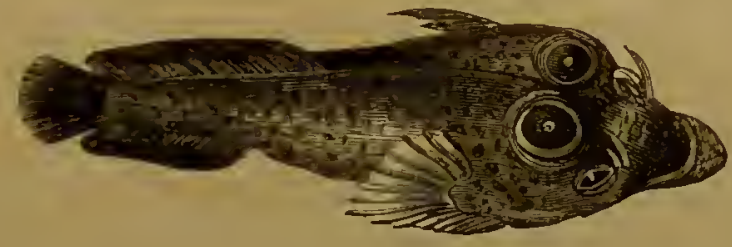

CURNISH SUCKER.

power remains. They are about 4 inches in length, and live on small shrimps and sandhoppers, which they swallow whole. They are purplish in colour, with a shade of pink, or they may be more of a crimson tint. Behind the eyes are two round spots, and the head is broad there, and has some tendrils on it; but in front it is long and rounded off. The tail is small; the sucker is on the under part of the body behind the head.

Montagu's Sucker is another of these remarkable fish, and is common on the shores of Cornwall and Devon, and also of Ireland. In the spring, $\mathrm{Mr}$. 
Couch says, it is found near low-water mark, not unfrequently left by the tide, and lying hid underneath a stone, in which position when uncovered, without much effort to escape, it usually assumes the curious habit of throwing its tail forward towards the side of the head. They feed on Sandhoppers. When some of the fish were placed in a bottle with seawater, they readily attached themselves to the glass by their suckers, and even hung back downwards, they fixed and unfixed themselves with ease. Gowan's Sucker, or the Connemara Sucker, appears to be limited to particular districts on the west coast of Ireland, and is found under stones or in shallow water at very low tides. It is a very pretty fish, being, however, only $2 \frac{1}{2}$ inches in length. It has not the round spots mentioned in the description of the Cornish Sucker, and the tendrils or cirri near the nostrils are few in number. The general colour is orange-red, or a paler colour, and there are often two common lines running from behind the eyes, downward to the sucking organ. The eye has red radiations from the pupil. The tail is round, and the central rays are much lengthened.

The Shanny, or Smooth Blenny, is found on our shores, but is scarce on the east coast and in the north of Scotland. It haunts rocky places from which the tide retires slightly. There it hides itself under a stone in a moist place where weeds abound, or it remains for an hour or two, until released by the tide, or it creeps into a hole in the rock awaiting the rising of the sea. Its head is always seaward or outward, and it backs into a deeper part of its 
retreat by the help of its pectoral and ventral fins. Couch says "that it is through an instinctive feeling of pleasure as well as of safety that this fish will quit the water for a time; and it is scarcely to be doubted that by this means, also, it secures a renewal of health and vigour, for when its resort is in a pool of the rocks from which the sea camnot retire, it climbs some elevated spot that is out of water and there basks in the sunshine. But in this situation it exercises so large an amount of watchfulness that on

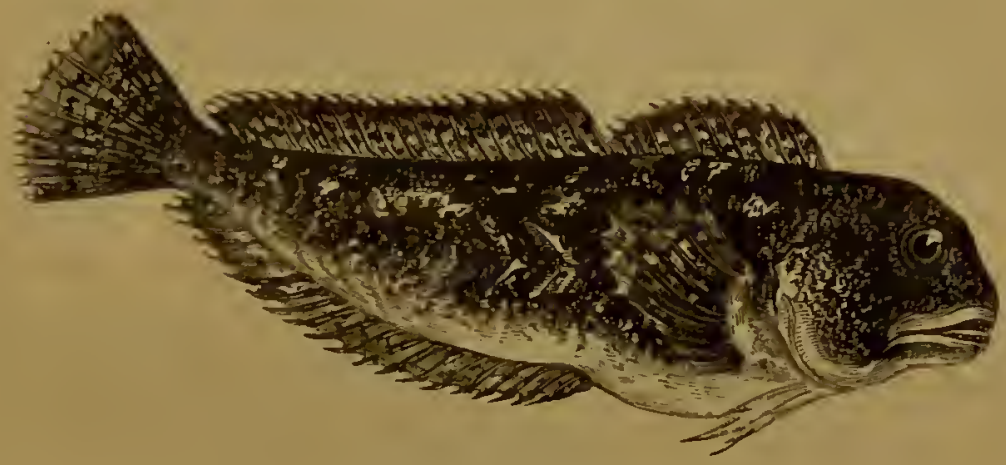

SMOOTH BLENNY.

the approach of any object, and before it could be supposed that the object was seen, the fish is said to plunge into the pool with great agility. Once in the water, it swims quietly to a crevice or nook where it can lie safely. Nor is this vigilance without sufficient cause, for it is liable to be sought out by the sharp bills of the Cormorant and Shag, which are often found diving in the neighbourhood of its resort." One which was kept for six months, did not grow, and it often varied in colour. In warm weather it basked on a stone for hours together, so that in 
summer, full half of its time was spent out of water. When the weather became colder it removed under water, and in time of great cold it sought the shelter of a stone, and remained there until the weather became more genial. It has a very slimy skin, which has much to do with its being able to live so long out of water. In fact, it will keep alive for days, if covered up with moist sea-weed. A French naturalist, Lacepede, recorded an instance where a Shanny had gone in at an oyster and had got shut up inside the shells. The oyster was dredged, taken for a considerable distance, and finally when it was opened the fish escaped. As the flowing tide, writes Couch, comes to its habitation in the rock, the Shanny is seen to glide from it in search of food, which is whatever it can obtain of an animal substance; and of which, with its well-arranged cutting teeth, it bites off portions with an apparent struggle, before it swallows them. It feeds also on small shell-fish and barnacles. It is very combative, and likes to feed alone; and when it fights, it holds on like a bulldog. These fish are heavy in the body and head for their size, and they have no air-bladder. They seldom exceed 5 or 6 inches in length; the head is large and fleshy, with full cheeks; the forehead is high, the lips are membranous, and the teeth are in an even row, with a single canine tooth in each lower jaw. The eyes are high in the head, and curious finger-shaped feelers are seen when the fish is in the water, near the nostril. The body is compressed, smooth, and tapers to the tail, which is round. The fins have fleshy rays, and the ventral 
fins are firm, finger-like projections partly divided in two. The colour varies; sometimes it is almost uniformly deep green, or mottled with yellow and white. Another Blenny, the Shanny being one, is called after Montagu; it has a curious crest, like a fin on the top of the head. It is a rare rock fish.

There are some little fish which are remarkable for their being slender, having most of their fins set far back near the tail, and for having the upper parof the face or jaw short, and the lower long and protruding. They look as if an accident had occurred to them, and that their upper jaw has been broken off short, the lower being left. These "Halfbeaks" have been found in the rock-pools on rocky coasts, but very little is known about their habits, and it is quite possible that they only conie near land, at certain times. Why they should be so deficient in the jaws can hardly be explained, but Mr. Couch considered that Swainson, the ornithologist, having explained the habits of a bird, the Skimming Tern, which has a short upper and long lower beak, a similar function might be assigned to the fish. The Terns skim along the surface of the sea, and feed on those minute animals which are only to be found there. It is probable that the fish do the same, and live near the surface. The Half-beaks have green bones, and much resemble the Gar-fish, but they are only a few inches long.

The Pipe-fishes, or Sea Adders, have the face, in front of the eyes, made into a sort of snout lengthened into a tube, at the end of which is the mouth. This is small, and the lower jaw closes over it like a 
cover. The gills are in small round tufts, and the body is covered with regularly-arranged plates, which give it an angular appearance. Some are called Sea Horses, and look covered with armour, and others are long and have a long vibrating fin on the back. Most of them live beyond the shore, but the Worm Pipe-fish is an exception, and is thus noticed by Mr. Jonathan Couch in his book on the "Fishes of the British Islands":- "In its habits this little fish differs from all others of its family; and while one of the most common, it appears to be the least numerous. Observation seems to show that it is not able to raise itself above the ground on which it creeps, and in its endeavours to escape being caught, it moves with a serpentine motion much like that of the slow-worm. It is commonly found near low-water mark, where it seeks shelter under a stone, more frequently singly, but sometimes in company with several others. There is no proof that it ever goes into deeper water." The young have the tail covered with a fin-like membrane, which extends some way up the back and along the lower surface to the vent, and there are also pectoral fins; but subsequently these disappear in part. The fish does not exceed 5 or 6 inches in length, and the body is round, and of less size than a common quill. The eye is near the top of the head, the snout is turned upward in an arched form, and the nostrils are close in front of the eye. "The colour," writes Mr. Couch, " is in some quite black, with a row of pale whitish spots along the back, which near the head are distant from each other, but they are closer together near 
the tail. In some, the colour is of various shades of brown, and the cheeks are mottled with defined patches of pale yellow."

An ugly fish is often found underneath sea-weeds on muddy shores, hidden up by a stone. It is long for its breadth and height, has a flat head, prominent eyes, and there are two feelers or barbs on the upper jaw and one on the lower. It is about a foot or I4 inches in length, and the colour is rather uniform, the back and sides being chestnut-brown. But the fish is often found in deeper water, and then it is of a brighter and yellow red tint with spots. This Three-bearded Rockling is often accompanied by one with five feelers or barbs, which is called the Five-bearded Rockling. Mr. Couch's son, at one time living at Polporro, noticed that this fish was a nest-maker. "The nest shows considerable skill, perseverance, and energy." It is invariably formed of the common Coralline in large quantity, put together without skill or arrangement, thrust into some cavity or crevice of a rock close to low-water mark, and the materials are maintained there by no other bond than that of compression. And as the coralline of which it is formed is not sometimes to be found within the distance of over 200 feet of the selected spot, it must be gradually collected, and brought with a degree of perseverance at least equal to the intelligence displayed in the construction." Much force is used by the fish in cramming the coralline into creeks and crevices in the rocks. It lays its eggs in sand amongst the mass, and therefore deposits them as it proceeds with its 
nest-building. These nests were observed in the spring, but others, doubtless, are formed later on.

The last fish to be noticed as a true dweller of the shore, is called the Lesser Launce, known in some places as the Sand-eel. They swim in companies of a few scores or hundreds, and in the quiet days of summer, writes Couch, are seen at a small depth ${ }^{-}$in the water, as they are pursuing their lively course in bays or harbours - where, however, their fate is usually an unfortunate one. Unable to protect themselves, they are an attractive prey to the hungry rovers of the sea, who here and there make a plunge

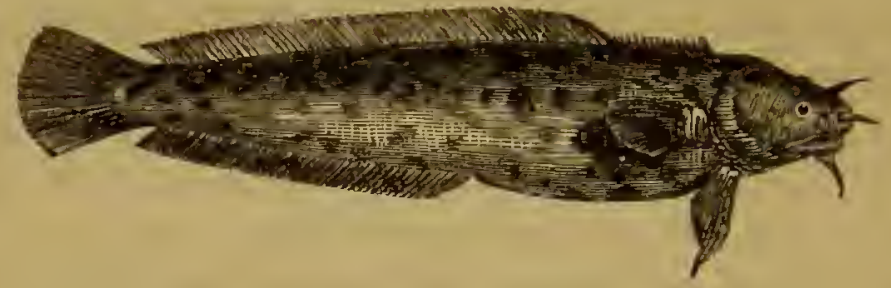

BEARDED ROCKLING.

into the midst of them. After being chased and frightened, they find safety by piercing into the soft sand of the bottom, beneath which, a pointed process at the end of the jaw enables them to bury themselves. They lie there, even after the tide has receded. This small fish is long in the body and almost cylindrical, and the long back and belly fins are not united near the tail. It has no air-bladder, and looks like a little lance-head to a spear. It is not an eel, but belongs to a different group of fish altogether. When in the sand or mud this fish occasionally lays its roe, and the eggs hatch under this covering. These fish may be sometimes dug up. 


\section{CHAPTER XIII.}

The Shore Birds :-The Ox-birds-The Ringed Plover-The Godwits-The Knots-The Golden Plover-The Grey Plover-The Waders-The Large Curlew-The Whimbrel -The Redshanlis-The Greenshanks-The SandpipersThe Cormorants-The Sea Swallows-The Turnstones and Stints-The Gulls.

THE commonest shore-bird is, undoubtedly, the Dunlin or Ox-bird (Tringa zariabilis), which goes in large flocks on most parts of the sea-coast in England. Even when the bulk of the shore-birds have gone north to breed, numbers of the Dunlin are still flying about during the whole summer, apparently bachelors and old maids. In the autumn a great influx of arrivals takes place, and then the Ox-birds are extremely plentiful, settling sometimes on the seabeach in such numbers that they form black patches, which may be seen a long distance off. On being alarmed they sail out to sea in close order, wheeling very swiftly just above the waves, and then returning to settle, generally at some distance from their former place of rest; and above everything they choose a sandy spot running out into the sea. During the heat of the day, when the tide is up, they settle on the beach and rest, and they can often be approached quite closely in a boat, or by crawling along the shore, when they are seen preening their feathers, or resting 
asleep with their bills under their shoulder feathers and balanced on one leg. At the same time there is generally one bird, here and there, on the alert, who gives the alarm if anything suspicious comes in sight, and the whole flock is off in an instant. In the summer the Dunlin is reddish in colour, with a black horse-shoe on his breast; and the young birds are also reddish, but with black markings instead of the horse-shoe mark on the breast; and in winter the plumage is gray above and white below. The autumnal flocks consist generally of young birds, and they are at first very tame, but gradually become wild, if shot at frequently. Their guardian angel is the Ringed Plover, a most tiresome bird for the sportsman or collector. On some parts of the south coast this bird is called the "Wide-awake," and wideawake enough he is, giving the alarm-note if approached within a hundred yards, and starting all the birds within hearing. In the spring these little plovers are not so shy, and they lay their two pearshaped eggs on the bare shingle without any nest: the young ones, when first hatched, are of so light a brown that they exactly resemble the ground; and they generally save themselves by squatting down, so that it is impossible to see them, unless they can be induced to move again. In the autumn they associate with the Ox-birds, rendering the latter shy and wary, and it becomes very difficult to stalk them.

In the month of May, the shore-birds arrive, in great beauty, the Godwits and the Knots having their red breasts, while the Golden Plover and the 
Grey Plover have put on their black breasts, and all the Waders are now handsomer than at any other time. In the autumn they return on their southward migration, but then in their winter plumage, which is mostly gray or brown, while the breasts are white.

The best place for making the acquaintance of our larger Waders, will be found in a visit to one of the tidal harbours. There, when the tide is out, the soft whistling notes of the active little birds will be heard on all sides; and far out on the mud may be seen, feeding, the large Curlew and the Whimbrel, while the pipe of the Redshanks or the Greenshanks will fall on the ear. Proceeding up the little creeks and gullies, which become navigable as the sea flows in, the boat will startle the birds into active flight, and the first to be seen skimming along with the wings almost touching the water, will be the common Sandpiper, or Summer Snipe. He will fly until nearly out of sight, and settle again on the side of the mud-banks: then from the green weed on the higher mud, will fly a Green Sandpiper with a most erratic course, and showing a great deal of white as he rapidly disappears round the nearest bend. A few Cormorants will occasionally pass over, flying high in the air with outstretched neck, while in the broader channels the fairy-like little Terns or Sea-swallows will hover for a few seconds and then dip into the water after their prey, settling only to rest for a moment or two on the mud, soon to be covered by the encroaching sea. At last the harbour is full, and as no more feeding is to be done, the birds are off to the beach, where they patiently 
wait till the tide begins to fall again. Then they are hard at work along the shore, picking up food as the water retires, and following the receding waves as they roll further and further back. The mud must be well uncovered before the first flocks return to the harbour, where they will continue feeding till the next rise of the tide drives them to the outer beach. When the tide is low, during the night, the shore-birds may be heard calling almost as much as in the daytime, and a large part of the migration takes place during the hours of darkness. Besides the species mentioned, there may occasionally be observed the Turnstone, the Little Stints, and several kinds of Gulls. The latter, however, are more denizens of the sea, and do not often frequent the sea-shore, except at low-tide, for the purpcses of feeding, when they are often in company with Rooks and Crows.

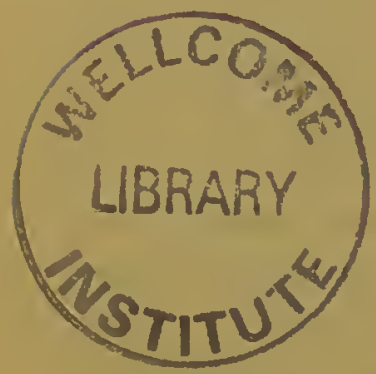

THE END.

WTMAN AND SONS, PRINTRRS, GREAT QUEBN STBEBT, LONDON. 


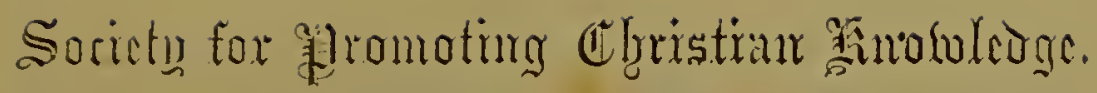

NATURAL HISTORY RAMBLES,

Fcap. Svo., Cloth boards, 2s. 6d. each.

\section{LANE AND FIELD.}

By the Rev. J. G. Woon, M.A., Author of "Homes without IIands," \&.c., \&c.

\section{LAIKES AND RIVERS.}

Ly C. O. Groom Napier, F.G.S., Author of "The Food, Use, and the Beauty of British Birds," \&ic., Sic.

\section{MOUNTAIN AND MOOR.}

By J. E. TAYlor, Editor of "Science-Gossip."

\section{THE SEA-SHORE.}

By Professor P. MARTTIN DuxCa., M.B. (London), F.R.S.,

Ifonorary Fellow of King's College, London.

\section{UN D ERGROU N D.}

Ly J. E. TAY LOR, Editor of "Science.Gossip."

\section{WOODLANDS.}

Dy M. C. CONKE, M.A., LL.D. 


$$
(2)
$$

Beauty in Common Things. Illustrated by $\mathrm{I} 2$ Drawings from Nature, by Mrs. J. W. Whymper, and printed in Colours, with descriptions by the Author of "Life Underground," \&c. 4to. ............ Cloth boards io G

Botanical Rambles. By the late Rev. C. A. Jorrss, B.A., F.L.S. With illustrations and woodcuts. Royal I 6 mo.......................................... Cloth board's

Flowers of the Field. By the late Rev. C. A. JoHns, B.A., F.L.S. With numerous woodcuts. Fcap. Svo................................... Cloth boarits 
British Animals. With 12 coloured plates. 16 mo.

Birds of the Sea-shore. With I 2 coloured plates. $16 \mathrm{mo}$. Cloth boards

Evenings at the Microscope; or, Researches among the Minuter Organs and Forms of Animal Life. By Philip IIENRY Gosse, F.R.S. A new Edition revised and annotated. With II2 woodcuts. Post Svo. Cloth boards

Familiar History of British Fishes. By Frank BuCKLAND, Inspector of Salmon Fisheries ior England. and Wales. With a Frontispiece and 134 woodcuts. Crown Svo. ...................................... Cloth board's

Natural History (Illustrated Skctches of); consisting of Descriptions and Engravings of Animals. With numerous woodcuts, in 2 vols. Fcap. 8vo.

Series I. and II.

Our Native Songsters. By Anne Pratt, Author of "Wild Flowers." With 72 coloured plates. $16 \mathrm{mo}$. Cloth boarits 8 o

Selborne (The Natural History of). By the Rev. GilberT White. With Frontispiece, Map, and $5^{\circ}$ woodcuts. Post Svo. .........................Cloth boarils

Ocean (The). By Philip Hexry Gosse, F.R.S,. Author of "Evenings at the Microscope." With 5 I illustrations and woodcuts. Post Svo. Cloth boarils

Deiv-drop and the Mist (The): an Account of the Phenomena and Properties of Atmospheric Vapour in various parts of the World. By ChARLES ToMLinsox, F.C.S. With woodcuts and cliagrams. Icap. Svo. 
Frozen Stream (The): an Account of the Formation s. $d_{0}$ and Properties of Ice in various parts of the World. By Charles Tomlinson. With woodcuts and diagrams. Fcap. 8vo. .........................Cloth boards

Rain-Cloud and Snore-Storm: an Account of the Nature, Formation, Properties, Dangers, and Uses of Rain and Snow. By Charles Toxilinson. With numerous woodcuts and diagrams. Fcap. Svo. Clntis

Tempest (The): an Account of the Origin and Phenomena of Wind in various parts of the World. By Charles TOMLINSON. With numerous woodcuts and diagrams. Fcap. Svo......................... Cloth boarls

Thunder-Storm (The) : an Account of the Properties of Lightning and of Atmospheric Electricity in various parts of the World. By CHARLES TOMLINSON. With numerous woodcuts and diagrams. Fcap. 8vo. Cloth boards

IInter in the Arctic Regions and Summer in the Antarctic Regrions. By Charles Tomlinson. With two maps, and several illustrations and woodcuts. Crown sro. Cloth boarils

\section{通epositories:}

77, GT. QUEEN STREET, LINCOLN'S INN FIELDS, W.C.; 4. ROYAL EXCHANGE, E.C. ; \& 48, PICCADILLY, W., 
.

$+2$

\section{.}

4 
-

$+$ 


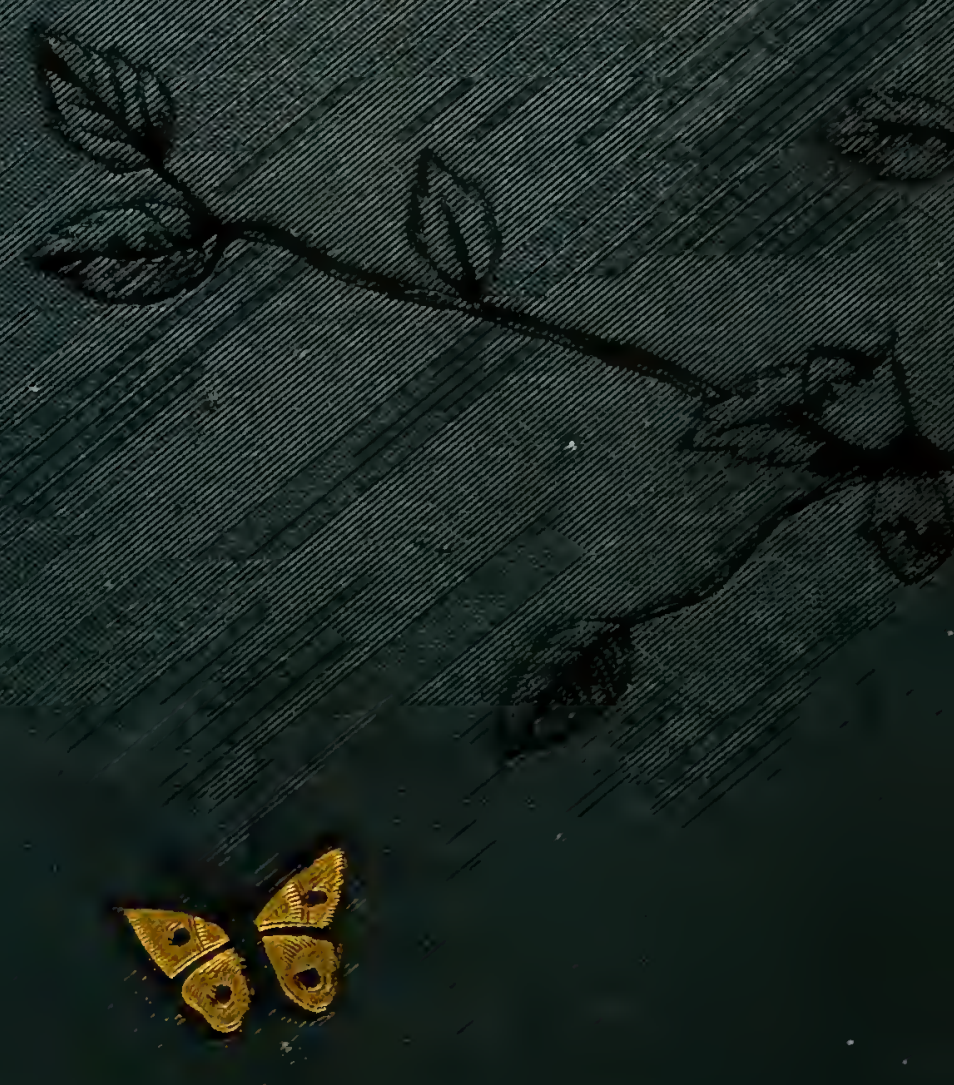

